\title{
BetTing Big: VALUe, CAUTION AND ACCOUNTABILITY IN AN ERA OF LARGE BANKS AND COMPLEX FINANCE*
}

\author{
LAWRENCE G. BAXTER ${ }^{* *}$
}

\begin{abstract}
Big banks are controversial. Their supporters maintain that they offer products, services and infrastructure that smaller banks simply cannot match and enjoy unprecedented economies of scale and scope. Detractors worry about the risks generated by big banks, their threats to financial stability, and the way they externalize costs of operation to the public. This article explains why there is no conclusive argument one way or the other and why simple measures for restricting the danger of big banks are neither plausible nor effective.

The complex ecology of modern finance and the management and regulatory challenges generated by ultra-large banking, however, cast serious doubt on the proposition that the benefits of big banking outweigh its risks. Consequently, two general principles are proposed for further consideration. First, big banks should bear a greater degree of public accountability by reforming certain principles of corporate governance to require greater representation of public interests at the board and executive levels of big banks. Second, given the unproven promises of performance by big banks, their unimpressive actual record of performance, and the many hazards they inevitably generate or encounter, financial regulators should consciously adopt a strict cautionary approach. Under this approach, big banks would bear a very heavy onus to demonstrate in concrete terms that their continued growth - and even the maintenance of their current scale - can be adequately managed and supervised.

\footnotetext{
* (c) Lawrence G. Baxter.

** Professor of the Practice of Law, Duke Law School. I wish to thank my research assistants, Daragh Murphy, Duke LLM 2012, for his energetic research and numerous helpful ideas, and Brian Berger, Boston University J.D. 2014, for his helpful research assistance. I would also like to thank Jim Cox, Lissa Broome, Ray Natter and Lucy Chang, Duke J.D. 2012, for their helpful comments on various drafts.
} 
Table of Contents

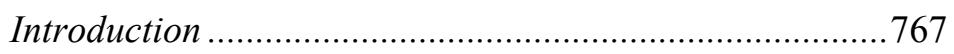

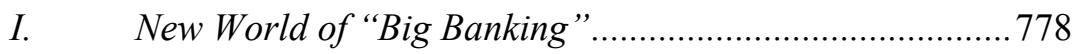

A. "Deepening Global Finance" ........................................ 778

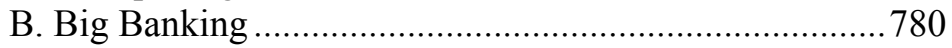

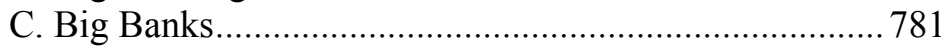

1. Universal Banks.................................................... 782

2. Retail and Commercial Banks .................................. 783

3. Investment Banks....................................................... 783

4. Investment Servicers and Managers ..........................783

D. Value of Big Banks.................................................... 786

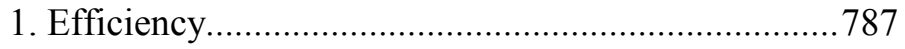

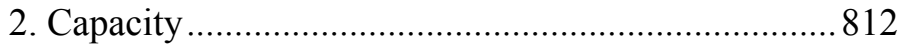

3. Global Competitiveness.......................................... 816

4. "Instrumentalities of the State" ................................ 818

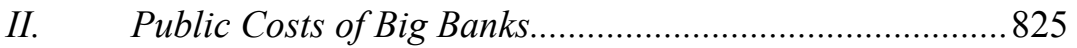

A. Direct and Indirect Public Subsidies.............................. 827

B. Market Power and Repression of Competition............. 831

C. Distorting Political Influence ......................................... 833

D. Costs of Regulation and Supervision............................. 836

1. Evolving Dimensions of Risk ................................... 838

2. Basel II and the Failures of Institutional

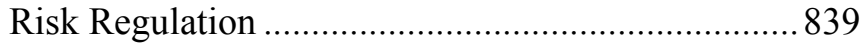

3. The Dodd-Frank Act and Basel III .......................... 845

III. Scale, Complexity and Financial Stability........................848

A. Banks Are Indeed Still Special ...................................... 849

B. Complexity Science and New Perspectives on

Risk Management ......................................................... 852

1. Essence of Complexity and Its Relevance to Financial Markets .................................................... 854

2. Power and Fragility in Complex

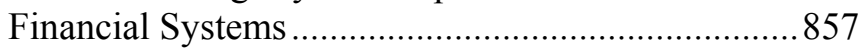

3. Layers of Complexity in Financial Markets ............. 861

IV. $\quad$ Two General Consequences for Public Policy .................. 868

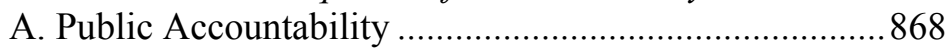

B. Progressively Tighter Restrictions on Bank

Growth and Diversification 


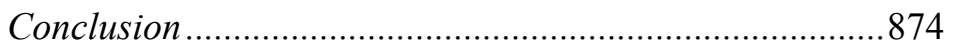

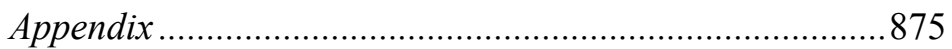

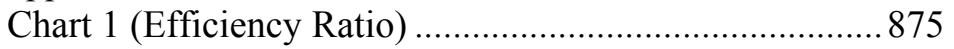

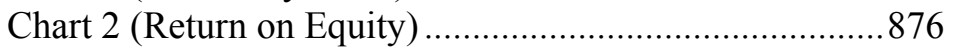

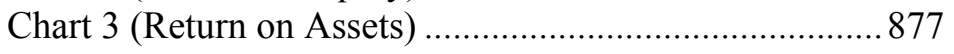

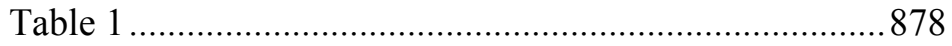

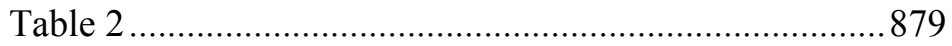

"Companies big and small will still need underwriting, credit, capital management, and advice. McKinsey did a report that showed that the credit needs of multinationals are going to double in the next ten years," ... . The net worth of the world is going to double in the next decade. Institutional funding will double in the next ten years. We're a store, you can buy bonds, FX, advice-we provide great products at a great price. That store is not going to go away. If you're a big, smart investor and we can give you the best price and the best service, you'll still be coming here, just like Wal-Mart and Costco."

\section{Introduction}

Big banks ${ }^{2}$ stir great controversy. They always have-more so since the worldwide financial and economic crisis of 2008

\footnotetext{
${ }^{1}$ See Gabriel Sherman, The End of Wall Street As They Knew It, N.Y. MAG. (Feb. 5, 2012), http://nymag.com/news/features/wall-street-2012-2/ (quoting Jamie Dimon, CEO of J.P. Morgan Chase \& Co., describing his vision of the future of banking).

${ }^{2}$ For stylistic purposes, this article will refer variously to "big banks," "universal banks," "large, complex financial institutions" ("LCFIs") and other terms designating different kinds of very large financial institutions. These are described more fully later. See infra text accompanying notes 5277. All of them share, or have the potential to share, one common characteristic: as a result of the scale and complexity of their operations, they can have a critical impact on financial stability. See infra text accompanying notes 326-336.
} 
("Financial Crisis" or "Crisis") ${ }^{3}$ - and probably always will. Few names ignite debate more quickly than those of financial institutions such as J.P. Morgan Chase, Citibank, Goldman Sachs, or Bank of America. ${ }^{4}$ Partisans of the right and the left unite in condemning bank bailouts, the compensation bank executives receive and the political power banks wield. For years, many informed individuals have worried that these financial behemoths have grown too large, too powerful, too complicated to regulate and too dangerous for global and domestic financial stability. These critics include politicians, ${ }^{5}$ leading regulators, ${ }^{6}$ economists and commentators

\footnotetext{
${ }^{3}$ Various terms have been used to describe the Financial Crisis, depending on whether one is focused on the United States economy or the global impacts (in which case the term "Global Financial Crisis," of GFC, is often used). The domestically focused term will be used in this article.

4 Throughout this article the following abbreviations may be used: "Barclays" for Barclays PLC; "Bank of America" for Bank of America Corp.; "Citi" for Citigroup Inc.; "Deutsche" for Deutsche Bank AG; "Goldman" for Goldman Sachs Group, Inc.; "JP Morgan" for JP Morgan Chase \& Co.; "Lloyds" for Lloyds Banking Group Plc; "Merrill" for Merrill Lynch \& Co, Inc.. (now wholly owned by Bank of America); "RBS" for Royal Bank of Scotland Group Plc; "Wells" for Wells Fargo \& Co. A specific reference to any particular component of these conglomerates will use the legal title.

${ }^{5}$ During the major debates leading to the passage of the major statute on financial reform in the United States, the Dodd-Frank Wall Street Reform and Consumer Protection Act ("Dodd-Frank Act"), Senator Bernie Sanders unsuccessfully introduced a bill entitled "The Too Big to Fail, Too Big to Exist Act of 2009," designed to impose limitations on bank size. Too Big to Fail, Too Big to Exist Act of 2009, S. 2746, 111th Cong. (2009). Subsequently, Senators Sherrod Brown and Ted Kaufman also unsuccessfully introduced an amendment that would have imposed limits on LCFI size. Press Release, Sherrod Brown: Senator for Ohio, Brown, Kaufman File Amendment on Too Big to Fail Legislation (Apr. 29, 2010), available at http://brown.senate.gov/newsroom/press_releases/ (search "Brown, Kaufman File Amendment on Too Big to Fail Legislation", follow the hyperlink by the same name). Congress included in the final version of the Dodd-Frank Act the so-called Kanjorski Amendment, which authorizes the Board of Governors of the Federal Reserve System ("Fed") to order divestiture of assets and subsidiaries where it believes that a systemically important financial institution ("SIFI") should do so in order to reduce its threat to financial stability. The Dodd-Frank Wall Street Reform and Consumer Protection Act, Pub. L. No. 111-203, § 121, 124 Stat. 1376, 1410-11 (2010) [hereinafter Dodd-Frank Act] (to be codified at 12 U.S.C. § 5331). As of this writing, this power has not been formally exercised.
} 
simply too numerous to list. ${ }^{7}$ Such sentiments run wide, crossing traditional political lines, ${ }^{8}$ and the issue could be a relevant force in

${ }^{6}$ In the United States, at least three Presidents of the various Federal Reserve Banks (Gary Stern of the Minneapolis Fed, Richard Fisher of the Dallas Fed, and, somewhat more guardedly, Thomas Hoenig of the Kansas City Fed) have spoken repeatedly in favor of breaking up big banks. See generally GARY H. STERn \& RON J. FELdman, TOO BIg To Fail: THE HAZARDS OF BANK BAILOUTS (2004); Richard W. Fisher, President and CEO, Fed. Reserve Bank of Dallas, Taming the Too-Big-to-Fails: Will Dodd-Frank Be the Ticket or is Lap-Band Surgery Required? (Nov. 15, 2011) (transcript available at http://dallasfed.org/news/speeches/fisher/2011/ fs111115.cfm). The recent former Chair of the Federal Deposit Insurance Corporation ("FDIC"), Sheila Bair, has also forcefully expressed this view since leaving office. Sheila Bair, Why it's Time to Break Up the "Too Big to Fail" Banks, CNN MONEY (Jan. 18, 2012, 10:56 AM), http://finance.fortune.cnn.com/2012/01/18/big-banks-break-up-bair/. In the United Kingdom, leading regulators, including the Governor of the Bank of England, Mervyn King, and the director of the Bank of England's Department for Financial Stability, Andrew Haldane, have frequently expressed similar held views. See, e.g., Mervyn King, Governor, Bank of England, Banking: From Bagehot to Basel, and Back Again (Oct. 25, 2010) (transcript available at http://www.bankofengland.co.uk/publications/ speeches/2010/speech455.pdf) (discussing potentially radical reforms); Andrew G. Haldane, Exec. Director for Fin. Stability, Bank of England, Control Rights (and Wrongs) (Oct. 24, 2011) (transcript available at http://www.bankofengland.co.uk/publications/speeches/2011/speech525.

pdf).

${ }^{7}$ See, e.g., Banking Industry Insiders Call for Breaking Up Giant Banks, WASHINGTON's BLOG (Apr. 7, 2010), http://www.washingtonsblog.com/ 2010/04/banking-industry-insiders-call-for-breaking-up-giant-banks.html; $A$ list: Experts who Want to Break Up the Big Banks, REPOWATCH (Apr. 17, 2011), http://repowatch.org/2011/04/17/ a-list-experts-who-want-to-breakup-the-big-banks/.

${ }^{8}$ When the Brown-Kaufman Amendment was defeated, one commentator observed that the vote in favor represented "a fascinating coalition-liberals and conservatives, Democratic leadership and three Republican conservatives." Tim Fernholz, On the Death of Brown-Kaufman, AM. PROSPECT (May 7, 2010), http://prospect.org/article/death-brown-kaufman. Big banks are the target of radical movements such as Occupy Wall Street and the Tea Party. See generally Gary Rivlin, Which Bank is the Worst?, DAILY BEAST (Oct. 25, 2011, 6:48 PM), http://www.thedailybeast. com/articles/2011/10/25/why-occupy-wall-street-hates-the-big-banks.html; Ned Ryun, OWS and Tea Party Agree: Big Banks Are a Big Problem, 
the United States presidential election in November 2012. ${ }^{9}$ In popular perception, big bank executives have become the robber barons of the twenty-first century. ${ }^{10}$

A full three years after the Financial Crisis, the January 2012 World Economic Forum at Davos presented the public with diametrically opposed perceptions of the value and dangers of big banks. On one side, the public interest non-profit PublicCitizen submitted a petition for the break-up of one of the world's largest universal banks, Bank of America. ${ }^{11}$ Bloomberg ran a trenchant column attacking the celebrity status accorded to the chief executive officer ("CEO") of Citibank, another one of the world's largest banks. ${ }^{12}$ To the columnist, such status "confirm[ed] once again that

HUFFINGTON POST (Nov. 16, 2011, 9:18 PM), http://www.huffingtonpost. com/ned-ryun/ows-and-tea-party-agree-b_b_1098611.html.

${ }^{9}$ Republican primary candidates for the 2012 nomination have also made elimination of ultra-large banks a part of their platforms. See, e.g., Simon Johnson, Why Not Break Up Citigroup?, N.Y. TIMES ECONOMIX (Nov. 17, 2011, 5:00 AM), http://economix.blogs.nytimes.com/2011/11/17/why-notbreak-up-citigroup (noting the positions of candidates Jon Huntsman and Newt Gingrich); Dan Freed, Gingrich Would Break Up Big Banks, THE STREET (Nov. 14, 2011， 11:24 AM) http://www.thestreet.com/ story/11309884/1/gingrich-would-break-up-big-banks.html (describing the similar positions of candidates Rick Perry and Newt Gingrich).

${ }^{10} \mathrm{In}$ an extreme example of the passions involved, the CEO of the largest banking conglomerate in the world, Josef Ackermann of Deutsche, was the target of a letter bomb in December 2011. Mr. Ackermann escaped injury, unlike his predecessor, Alfred Herrhausen, who was killed by an Italian terrorist group, the Red Army Faction in 1989. Aaron Kirchfeld, Ackermann Era Ends at Davos as Deutsche Bank CEO Cedes Power, BloOMBerg (Jan. 27, 2012, 9:20 PM), http://www.bloomberg.com/news/2012-01-27/ ackermann-era-ends-at-davos-as-deutsche-bank-chief-cedes-power.html.

${ }^{11}$ Letter from PublicCitizen to Ben Bernanke, Chairman, Bd. of Governors of the Fed. Reserve Sys., and Timothy Geithner, Sec'y of the Treasury (Jan. 25, 2012), available at http://www.citizen.org/documents/Public-CitizenBank-of-America-Petition.pdf. The author was not a signatory to the petition but did speak at the accompanying press conference in favor of presenting the petition as a means of testing the regulatory machinery designed to address large financial institutions that might pose a threat to financial stability.

12 Jonathan Weil, Pandit Does Davos, 0.1\% Gloat, Madness Reigns, BLOOMBERG VIEW (Jan. 26, 2012, 3:00 PM), http://www.bloomberg.com/ news/2012-01-26/pandit-does-davos-0-1-gloat-madness-reigns-

commentary-by-jonathan-weil.html. Two days earlier, Bloomberg published 
our world is stark mad,"13 an intriguing echo of the opposite view, expressed some weeks earlier, that attempts to impose curbs on the big banks were themselves "barking mad." 14

At Davos itself, general "madness" persisted. Big bankers were generally upbeat. Prominent CEOs interviewed at Davos extolled the virtues of large universal banks not only as effective business organizations but also as vehicles for promoting public welfare and financial stability. Robert Diamond, CEO of Barclays, offered a positive assessment of the importance of big banks such as his, even in the currently difficult economic conditions. ${ }^{15}$ His wellknown counterpart at JP Morgan, Jamie Dimon, spoke in similarly optimistic terms while being critical of the evolving regulation of big banks. ${ }^{16}$ One leading banker audaciously predicted still more powerful concentration. ${ }^{17}$

a report in which a leading investment analyst is quoted as saying, "[a]sking Vikram Pandit about the crisis in capitalism is like asking Alec Baldwin about airplane etiquette." Christine Harper \& Elisa Martinuzzi, Pandit Pariah No More as U.S. Bankers in Ascendance at Davos, BloOMBERG (Jan. 24, 2012, 12:20 PM), http://www.bloomberg.com/news/2012-0123/pandit-pariah-no-more-as-u-s-bankers-gain-ascendancy-at-davos.html.

For his part, Mr. Pandit adopted a much more conciliatory approach when interviewed at Davos. See generally Pandit Interview Jan. 26, BLOOMBERG (Jan. 26, 2012), available at http://www.bloomberg.com/video/84929556/.

${ }^{13}$ Weil, supra note 12.

${ }^{14}$ A few months before, the head of the British Confederation of Industry, Mr. John Cridland, declared that British reform proposals that would curb the operations of big banks were "barking mad." John Cridland, CBI Head, Says Further Banking Reform Would be 'Barking Mad,' HuFFPOST POLITICS (Aug. 30, 2011, 10:12 PM), http://www.huffingtonpost.co. uk/2011/08/30/john-cridland-director-ge_n_941443.html.

${ }^{15}$ Barclays CEO Sees "More Confidence" in U.S. Economy, BLOOMBERG (Jan. 26, 2012), http://www.bloomberg.com/video/84923984/; Stephen Grocer, Barclay's Diamond: Bankers 'Get It' on Pay, WaLl St. J. DeAl J. (Jan. 26, 2011, 4:05 PM), http://blogs.wsj.com/deals/2012/01/26/barclayssdiamond-bankers-get-it-on-pay/.

${ }^{16}$ See Antonia van de Velde, Dimon: Impact of Greek Default on US Banks Almost Zero, CNBC (Jan. 26, 2012, 8:43 AM), http://www.cnbc.com/ id/46144727. Mr. Dimon has been a persistent critic of various aspects of financial reform. See, e.g., Shira Ovide, Jamie Dimon: Wall Street Hero or Nutty?, Wall St. J. DeAl J. (Feb. 15, 2012, 8:42 AM), http://blogs. wsj.com/deals/2011/06/08/jamie-dimon-wall-street-hero-or-nutty/

(describing Mr. Dimon's argument that over-regulation could slow economic recovery and job creation); David Benoit \& Matthias Rieker, J.P. 
The stakes are high. If the bankers are right, then we ought to welcome the golden prosperity they promise. If the bankers are wrong, we could face catastrophe. Were a big bank to fail unexpectedly, as they have often done, ${ }^{18}$ financial markets would almost certainly be roiled and the possibility of another financial crisis would become very real. ${ }^{19}$ Nor is the possibility of substantial financial instability merely theoretical: major financial crises are, in fact, recurring in significant numbers. ${ }^{20}$ Evidence also suggests that

Morgan's Dimon Blasts Bank Regulations-Again, WALL ST. J. (Dec. 7, 2011, 4:33 PM), http://online.wsj.com/article/SB10001424052970203 413304577084403894858534.html ("In a speech at a Goldman Sachs financial-services conference, Mr. Dimon sounded defiant on several topics, but especially continued to criticize global regulations that look to force banks of J.P. Morgan's size to hold more capital, trim some trading operations and shrink risky assets.").

17 See Christine Harper, Incredible Shrinking Bankers at Davos Humbler Amid Austerity, BloOMBERG (Jan. 27, 2012, 1:33 PM), http://www.bloomberg.com/news/print/2012-01-26/incredible-shrinking-

bankers-at-davos-humbler-as-austerity-hits.html (quoting Anshu Jain, the incoming co-CEO of Deutsche, as saying that " $[\mathrm{t}]$ here's going to be, and is, powerful consolidation within our industry").

18 Several major LCFIs have failed both during the crisis and since. Examples include Wachovia, RBS, ING and Dexia. The list does not include more specialist institutions such as Indy Mac and Washington Mutual (savings associations), Countrywide (mortgage giant), AIG (nominally an insurance giant), Fannie Mae and Freddy Mac (government sponsored enterprises) or investment banks Bear Sterns, Merrill and Lehman Brothers. For a highly critical review of the massive bailouts of BofA, Citi and General Motors, see Janet E. Kerr, The Financial Meltdown of 2008 and the Government's Intervention: Much Needed Relief or Major Erosion of American Corporate Law? The Continuing Story of Bank of America, Citigroup, and General Motors, 85 ST. JoHN's L. REV. 49 (2011).

${ }^{19}$ Indeed, as of the writing of this article, the crisis in the Eurozone has generated significant anxiety concerning the systemic exposure of U.S. LCFIs. See, e.g., Peter Eavis, U.S. Banks Tally Their Exposure to Europe's Debt Maelstrom, N.Y. TIMES DEALB\%K (Jan. 29, 2012, 7:56 PM), http://dealbook.nytimes.com/2012/01/29/u-s-banks-tally-their-exposure-to-

europes-debt-maelstrom/ (documenting the concerns and hedging practices of large banks).

${ }^{20}$ See, e.g., MARTIN Wolf, Fixing Global FinANCE 31 (2010) (discussing the frequency of financial crises). For extensive catalogs of the various and voluminous forms of financial crises, see CHARLES P. KINDLEBERGER \& Robert Z. Aliber, Manias, PANics, AND Crashes: A History of Financial Crises (6th ed. 2011); CARMEn M. Reinhart \& Kenneth S. 
they are happening with greater frequency ${ }^{21}$ and with even greater impact, particularly if such crises occur after periods of benign economic conditions. ${ }^{22}$ Financial systems are more tightly connected and interdependent than ever, ${ }^{23}$ and great scale seems only to exacerbate the systemic impact that could be wrought by a major failure. $^{24}$

Yet there remains much to disentangle before we are able to assess the value of big banks and make coherent policy decisions about them. Dozens of official and semi-official reports, not to mention a vast array of books and articles, have attempted to explain the causes of the Financial Crisis. This body of literature is often muddled, contradictory and even self-contradictory. ${ }^{25}$

Nor should this murky state of affairs be a surprise. One thing upon which almost everyone can agree is that the global financial system experienced a major systemic crisis, ${ }^{26}$ not a mere linear concatenation of malevolent cause and damaging effect. Of course some of the proximate causes of the Financial Crisisexcessive leverage, high levels of securitization, regulatory failure and so on-seem clear enough. ${ }^{27}$ But how these and other factors

Rogoff, This Time IS DifFERENT: EIGHT CENTURIES OF FINANCIAL Folly (2009).

${ }^{21}$ See, e.g., Barry Eichengreen \& Michael D. Bordo, Crises Now and Then: What Lessons From The Last Era of Financial Globalization? 30 (Nat'l Bureau of Econ. Research, Working Paper No. 8716, 2002), available at http://www.nber.org/papers/w8716.pdf (concluding that "[r]elative to the pre-1914 era of financial globalization, crises are twice as prevalent today").

22 Viral V. Acharya \& S. Viswanathan, Leverage, Moral Hazard, and Liquidity, 66 J. FIN. 99, 99 (2011).

${ }^{23}$ The increase in interconnectedness from January 1994 to December 2008 has been measured by using network diagrams of statistically significant, Linear Granger-causality relationships among the largest financial institutions. Monica Billio et al., Econometric Measures of Connectedness and Systemic Risk in the Financial and Insurance Sectors 24-25 (Ca'Foscari Univ. of Venice Dept. of Econ., Working Paper No. 21/WP/2011, 2011), available at $\mathrm{http}$ ://papers.ssrn.com/sol3/papers.cfm?abstract_id=1963216.

${ }^{24}$ See infra text accompanying notes 326-336.

${ }^{25}$ For an excellent review of a number of major books written about the crisis, see Andrew W. Lo, Reading About the Financial Crisis: A 21-Book Review (Jan. 9, 2012) (unpublished manuscript), available at http://www.argentumlux.org/documents/JEL_6.pdf).

${ }^{26}$ See infra text accompanying notes 298-303.

27 See, e.g., Jennifer S. Taub, The Sophisticated Investor and the Global Financial Crisis, in Corporate Governance Failures: The Role of 
interacted to generate a financial and economic collapse of such scale will take years of research to understand fully. As in all complex systems, causation is difficult to pinpoint precisely because so many elements interact to drive the evolution of the system. ${ }^{28}$

Without firm agreement about causes and effects, the continued existence of big banks is hardly surprising. Despite surviving near death experiences during the Financial Crisis, ${ }^{29}$ big banks continue to operate worldwide, in some cases with greater scale $^{30}$ than the economies of whole countries. ${ }^{31}$ There seems little prospect, short of a financial disaster far greater than the Financial Crisis, that we will muster enough political will or economic justification to eliminate the dangers big banks present to financial

InSTITUTIONAL INVESTORS IN THE GLOBAL FINANCIAL CRISIS 188, 191-93 (James P. Hawley et al. eds., 2011) (providing a succinct review of major proximate causes of the meltdown and citing the reports that have attempted to parse these causes).

${ }^{28}$ For a highly technical exegesis of the classes of causation in complex systems, see George F. R. Ellis, On the Nature of Causation in Complex Systems (Mar. 20, 2008) (unpublished manuscript), available at http://www.mth.uct.ac.za/ ellis/Top-down\%20Ellis.pdf.

${ }^{29}$ To take but one example, Citi may well have been insolvent at the time of the Financial Crisis and was rescued on the basis of "gut instinct." NEIL M. Barofsky, Special Inspector Gen., Troubled Asset Relief Program, Summery of Report, in EXTRAORDINARY FINANCIAL AsSISTANCE PROVIDED TO Citigroup, INC. (Jan. 13, 2011), available at http://www.sigtarp.gov/ reports/audit/2011/Extraordinary\%20Financial\%20Assistance\%20Provided $\% 20$ to\%20Citigroup,\%20Inc.pdf.

${ }^{30}$ It is true that some such institutions have trimmed their scale and operations, and refocused their managerial attention onto narrower strategic goals. For example, Citi has reduced its total consolidated assets from $\$ 2.187$ billion at Dec. 31, 2007, to $\$ 1.874$ billion at Dec. 31, 2011, and recently announced that it would be exiting its proprietary trading business. Donal Griffin, Citigroup Exits Proprietary Trading, Says Most of Unit's Workers to Leave, BLOOMBERG (Jan. 27, 2012, 1:22 PM), http://www.bloomberg.com/news/2012-01-27/citigroup-says-most-

proprietary-trading-employees-to-leave-as-desk-closed.html.

31 For example, in 2010, BofA's amount of total assets $(\$ 2,264,909,000,000)$ was larger than the GDP of Canada $(\$ 1,577,040,000,000)$ and the U.K. $(\$ 2,250,209,000,000)$. See World Economic Outlook Data-September 2011, InTERNATIONAL MONETARY FUND (Mar. 22, 2012), http://www.imf.org/external/pubs/ft/weo/2011/ 02/weodata/WEOSep2011all.xls. 
stability. ${ }^{32}$ In the United States, both Congress ${ }^{33}$ and the Administration $^{34}$ have rejected the dramatic measures necessary to recreate a network of financial institutions sufficiently small enough to enable the effective operation of market. Indeed, it is precisely the refusal to adopt such measures that has infuriated many political activists and placed the question of big banks and their "too-big-tofail" ("TBTF") status on the electoral table.

This state of affairs is curious, continuing as it does in the wake of so massive a crisis. Despite the recognition that they constitute a threat to financial stability, huge banks are fiercely defended, not only by their own executives, but also by the regulators in control. The defense of big banks by regulators could, of course, reflect extreme regulatory capture. ${ }^{35}$ It might even evidence a kind of codependency in which big government needs big banks and vice versa. ${ }^{36}$ The situation might also reflect the possibility that we are undergoing an economic transformation, the mechanisms and eventual outcome of which are hazy at best. The CEO of Citibank has asserted that we are entering a new financial paradigm that is uncertain and undetermined. ${ }^{37}$ Perhaps he is right. ${ }^{38}$ Those who believe in the value of big banks seem to envisage a transformation in global finance that would make big banks much like other global

\footnotetext{
${ }^{32}$ It is also true that regulators have extended the power to force divestiture and reduce scale to SIFIs. See infra text accompanying notes 287-288. This power has not yet been used. It does appear, however, that regulators have put pressure on certain big banks to reduce their size and complexity. In the case of BofA, CEO Brian Moynihan has reportedly attempted to shed nonstrategic businesses as fast as possible. Jeff Horwitz \& Victoria Finkle, Bank of America Can't Get Smaller Fast Enough, AM. BANKer, Oct. 18, 2011 , at 3 .

33 See supra notes 5, 8 (discussing Congress' and the Obama Administration's rejection of outright size limitations).

${ }^{34}$ For reporting and discussion of the Administration's refusal to support size limitations on large banks, see Andy Kroll, Why Didn't Obama Back Busting Up Big Banks?, Mother JONES (May 7, 2010, 3:00 AM), http://motherjones.com/politics/2010/05/kaufman-brown-banks-obama.

${ }^{35}$ See, e.g., Lawrence G. Baxter, "Capture" in Financial Regulation: Can We Channel it Toward the Common Good?, 21 CORNELl J.L. \& PUB. POL'Y 175 (2011).

${ }^{36}$ See infra text accompanying notes 194-220.

${ }^{37}$ Pandit Interview Jan. 26, supra note 12.

${ }^{38}$ Whether this justifies the risks generated by very large banks is another matter.
} 
corporations. ${ }^{39}$ Perhaps big bank detractors do not sufficiently appreciate the overall value of big banks.

Yet big banks are not like other organizations. In a vast, complex and fragile "system of systems," big banks are connected more tightly than any commercial or industrial equivalent. ${ }^{40}$ The complex terrain within which they operate must be appreciated in order to assess the kinds of risks involved and the strategies that stand the best chance of maintaining financial stability. Because we resorted to familiar command-and-control techniques in an attempt to "stamp out" perceived causes of the Financial Crisis, we have gone about trying to address this complexity in the wrong ways, creating a situation in which we now have a bizarre combination of over- and under-regulation. ${ }^{41}$ It is becoming more important than ever to understand the fuller implications generated by the complexity of the financial environment and its participants, including not only the big banks themselves but also the markets in which they operate, the innovation these markets spawn, the rules attempting to police the markets and even the regulators themselves. This is a realization that is attracting serious consideration at the highest levels among leading regulators. $^{42}$

It is therefore timely to ask: What is the value to the public (and not just bank executives) that is promised by big banks? Part I of this article reviews the world of big banking and acknowledges the often-underappreciated value that big banks create. The nowshopworn debate over their "efficiency" will also be reviewed, but the enterprise of "efficiency" measurement will be left open simply because the results are too indeterminate. Viewed from the perspective of the banks alone, big banks generate considerable value in the global economy, and in the future they might produce much more. Yet the assessment does not end there.

\footnotetext{
${ }^{39}$ See infra text accompanying notes 48-50.

${ }^{40}$ See infra text accompanying notes 334-336.

${ }^{41}$ See infra text accompanying notes 368-371

${ }^{42}$ In particular, senior regulators at the Bank of England and the Office of the Comptroller of the Currency in the United States Treasury ("OCC"). See Andrew G. Haldane, Regulation or Prohibition: The $\$ 100$ Billion Question, 2 J. REG. \& RISK N. ASIA 101, 101-06 (2010) (examining the banking industry's external costs); CHARLES TAYLOR, EVOLUTION AND MACROPRUDENTIAL REGULATION (2011) (recommending evolutionary theory as a tool to help policymakers understand the financial industry).
} 
Part II addresses the high public costs of big banks, costs that are not internalized by the banks themselves but are instead borne by taxpayers and society in general. To make a full assessment of the value and role big banks play, we must balance both sides of the ledger before delimiting all the parameters of public policy. Big banks do, or might potentially, generate value, even enormous value. This does not mean, however, that only bank executives and shareholders should capture such value without also being charged costs that would otherwise be borne by society. ${ }^{43}$

Part III, proceeding on the assumption that it is both unlikely and even naïve to expect that we will reduce bank size to levels considered "safe," addresses the underlying reasons that we cannot just bet that those big banks will deliver on their promises of value. Part III considers some of the implications of size and complexity, both for financial stability and for the management and regulation of big banks. The traditional concept that banks are "special" is reviewed within the context of a growing body of science that identifies and explains why a system-oriented understanding of modern finance is so critical to the decision whether to promote or slow the growth of big banks.

In Part IV, this article offers two general propositions of public policy, neither of which have received much consideration in the host of literature and studies stimulated by the Financial Crisis. First, the partly subsidized nature of big banking, coupled with the uncertainties of successful continued growth and the severe impact of potential failure, implies the need for greater public accountability of big banks. The ramifications of this greater accountability need much reflection and refinement and would probably include modifications

${ }^{43}$ The notion that big banks "privatize the profits and socialize the costs" of their operations is in vogue and has a venerable pedigree. The concept can be traced to Andrew Jackson, and it has become popular again because it powerfully expresses one of the dilemmas inherent in big bank operations. See John Carney, Sorry, Andrew Jackson Probably Never Said That "Den of Thieves" Quote, Bus. INSIDER CLUSTERSTOCK (Jan. 27, 2010), http://articles.businessinsider.com/2010-01-

27/wall_street/29973450_1_prayer-book-federal-bank-andrew-jackson (discussing alleged quote from Andrew Jackson's address to Congress in 1836 "I have had men watching you for a long time and I am convinced that you have used the funds of the bank to speculate in the breadstuffs of the country. When you won, you divided the profits amongst you, and when you lost, you charged it to the Bank. ... You are a den of vipers and thieves"). 
to the normally applicable principles of bank governance. Second, it is important to err on the side of caution, instead of merely balancing the pros and cons of big banks, big bank mergers and the continued growth and complex organization of big banks. Instead, there should be placed on big banks a clear onus to demonstrate convincingly that the maintenance of their current size, growth or further diversification would properly internalize all the costs of their operations and potential risks to financial stability. This approach would depart from the traditional deference given to private industry, deference which has always assumed the effective impact of market discipline and the genuine threat of bankruptcy in the event of failure. Such discipline is not powerful enough to counteract the potentially huge destabilizing effects of a big bank gone bad. Instead, regulators ought to undertake the regulatory equivalent of "hard look review" when requiring assurances from big banks. These assurances would also need further consideration and refinement, but they would likely include more detailed merger plans, regulatory resources, strategy plans and funding commitments, building on the new "living will" requirements for big banks to provide structural and operational assurances that safe operations and rescues or closures are actually plausible.

\section{New World of "Big Banking”}

\section{A. "Deepening Global Finance"}

Globalization might have created an entirely new order of financial needs, which in turn might necessitate the existence of ultra-large banks for the global system to function properly. ${ }^{44}$ This, at least, is the view of the U.S. Treasury Secretary, Mr. Timothy Geithner, who has been a stalwart defender of these financial institutions. ${ }^{45} \mathrm{He}$ describes this new demand as representing a "financial deepening," which in turn requires U.S. banks to be wellpositioned to compete abroad. ${ }^{46}$ Big banks will become similar to

${ }^{44}$ See Noam Scheiber, The Escape Artist: How Timothy Geithner Survived, New RePublic, Feb. 10, 2011, at 13, 17 (discussing U.S. Treasury Secretary Timothy Geithner's view on the role of banks in the post crisis global financial system).

${ }^{45} I d$.

${ }^{46} I d$. 
global companies such as Microsoft. ${ }^{47}$ While the Secretary acknowledges that the risks for big banks and financial systems are greater, he believes these risks can be contained through regulation. ${ }^{48}$

The Secretary's reported views were immediately derided in comments by prominent bloggers. ${ }^{49}$ Yet such criticism also reflects

${ }^{47} I d$.

${ }^{48}$ Id. In response to Mr. Scheiber's request for Mr. Geithner to articulate his vision of a post-Crisis financial landscape, Mr. Scheiber reports as follows:

Geithner hunched his shoulders, pressed his knees together, and lifted his heels up off the ground - an almost childlike expression of glee. "We're going, like, existential," he said. He told me he subscribes to the view that the world is on the cusp of a major "financial deepening": As developing economies in the most populous countries mature, they will demand more and increasingly sophisticated financial services, the same way they demand cars for their growing middle classes and information technology for their corporations. If that's true, then we should want U.S. banks positioned to compete abroad.

"I don't have any enthusiasm for . . . trying to shrink the relative importance of the financial system in our economy as a test of reform, because we have to think about the fact that we operate in the broader world," he said. "It's the same thing for Microsoft or anything else. We want U.S. firms to benefit from that." He continued: "Now financial firms are different because of the risk, but you can contain that through regulation." This was the purpose of the recent financial reform, he said. In effect, Geithner was arguing that we should be as comfortable linking the fate of our economy to Wall Street as to automakers or Silicon Valley.

Id.

${ }^{49}$ See, e.g., David Dayen, Geithner: I For One Welcome Our New Financial Overlords, FiredoglaKe (Feb 14, 2011, 9:35 AM), http://news.firedoglake.com/2011/02/14/geithner-i-for-one-welcome-ournew-financial-overlords (criticizing Geithner for "saying out loud that what's good for Wall Street is good for America."); Simon Johnson, Geithner's Gamble, PROJECT SyndicATE (Feb. 22, 2011), http://www.project-syndicate.org/commentary/johnson17/English

(describing Geithner's view as a "deeply disturbing vision, one that amounts 
an insufficient understanding of the roles and operations of big banks and focuses only on the actual and potential risks created by big bank operations. The Secretary's views were not well expressed; nevertheless, they do depict a murky "big picture" vision that is leading ultimately to an industrial formation, described recently by the CEO of JP Morgan, as coming in ten years to resemble the global big box stores Walmart and Costco. ${ }^{50}$

Given the scale and momentum of global transformation, for good or ill, ${ }^{51}$ these views cannot simply be disregarded. To be sure, the ultimate value of this emerging large-scale industry is not by any means self-evident. Still, the vision is not only plausible; it is in some respects already a reality.

\section{B. Big Banking}

Big banks engage in a great variety of financial services from merchant banking to ATMs. The banks themselves usually group these services into the major categories of retail banking, commercial

to a huge, uninformed gamble with the future of the American economy . . . .$\left.\dot{5}^{\prime \prime}\right)$.

${ }^{50}$ See Sherman, supra note 1 (speculating that investment banks such as Goldman could not compete with universal banks like JP Morgan). Sherman quotes Mr. Dimon as stating:

Companies big and small will still need underwriting, credit, capital management, and advice. McKinsey did a report that showed that the credit needs of multinationals are going to double in the next ten years, ... The net worth of the world is going to double in the next decade. Institutional funding will double in the next ten years. We're a store, you can buy bonds, FX, advice-we provide great products at a great price. That store is not going to go away. If you're a big, smart investor and we can give you the best price and the best service, you'll still be coming here, just like Wal-Mart and Costco.

Id.

${ }^{51}$ For one of many critiques of the "financialization" of the global economy by big banks, see YANis VAROUfakis, THE Global MinOtar: AMERICA, THE TRUE ORIGINS OF THE FINANCIAL CRISIS AND THE FutURE OF THE WORLD ECONOMY (2011). 
banking, capital markets and payments and clearing services. ${ }^{52}$

Most people are familiar with retail banking, which provides deposit and lending facilities to consumers and small businesses, intermediating between savers and borrowers. ${ }^{53}$ Closely related, though less visible to ordinary members of the public, commercial banking involves providing cash management services, lending and trade finance to medium and large companies. ${ }^{54}$ Capital markets, or "corporate and investment banking" as it is often termed inside big banks, involves underwriting the debt and equity issuances of businesses and governments, thereby providing such issuers access to capital markets as an alternative or complement to traditional loan finance. ${ }^{55}$ All participants in the financial system, whether ordinary consumers or large corporations, depend on the payments, clearing and settlement functions provided by large banks, whether this be for payments by cash or check or the registration of securities, even though most consumers are generally unaware of these operations. ${ }^{56}$

\section{Big Banks}

Some big banks specialize in only one or two of the activities just described. Others combine all or most forms of banking under one conglomerate umbrella. The Clearing House ${ }^{57}$ adopts four categories of very large "banks." 58

\footnotetext{
${ }^{52}$ The best and most easily available description of these four main types of banking services is found in THE CleARING House, Understanding THE ECONOMICS OF LARGE BANKS 4 (2011) [hereinafter TCH BANK ECONOMICS], available at http://www.theclearinghouse.org/index. $\mathrm{html}$ ? $\mathrm{f}=073071$.

${ }^{53}$ See id. ("Retail banking serves both consumers and small businesses, holding deposits of savers and matching them with credit needs of borrowers.").

${ }^{54} \mathrm{Id}$.

${ }^{55} I d$.

${ }^{56} \mathrm{Id}$.

${ }^{57}$ Established in 1853, The Clearing House is an industry association based in New York City. It represents large U.S. financial organizations. See About Us, THE ClEARING HOUSE, http://www.theclearinghouse.org/index. html? $\mathrm{p}=070877$ (last visited Apr. 3, 2012).

${ }^{58}$ See TCH BANK ECONOMICS, supra note 52, at 5-7 (describing "universal banks", "retail and commercial banks", "investment banks" and "investment servicers and managers").
} 


\section{Universal Banks ${ }^{59}$}

These are financial institutions that provide a diversified range of financial services to their clients and customers, whether retail, governmental, corporate or institutional, and operate on a very large scale. Such services range from retail and commercial banking to investment banking, brokerage and trading, advisory, asset management, insurance, derivatives, proprietary trading, investing and financial risk management, private banking and wealth advisory services and more.

Universal banks stand in contrast to specialized financial institutions, such as credit card companies, or traditional, standalone retail and commercial banks, although universal banks might well own one or more of such specialized institutions within their holding company structures. Four such universal banks are headquartered in the United States: JP Morgan, Bank of America, Citibank and Wells Fargo ${ }^{60}$ Each has total assets of considerably more than $\$ 1$ trillion; ${ }^{61}$ together, at the end of 2011, they had assets totaling \$7.6 trillion, which constitutes sixty-one percent of the $\$ 12.4$ trillion in total assets held by banks in the United States. ${ }^{62}$

${ }^{59}$ See, e.g., George J. Benston, The Separation of Commerical and InVESTMENT BANKIng: ThE Glass-Steagall ACt ReVisited AND RECONSIDERED (1990) (analyzing the advantages and disadvantages of universal banking and specialized banking); JORDI CANALS, UNIVERSAL BANKING: INTERNATIONAL COMPARISONS AND THEORETICAL PERSPECTIVES (1997) (discussing the challenges facing universal banks and advantages over specialized financial institutions); ANTHONY SAUNDERS \& INGO WALTER, Universal BANKING IN THE United States: What Could We Gain? What Could We Lose? (1994) (analyzing the arguments for and against the United States banking system moving towards universal banking); Georg Rich \& Christian Walter, The Future of Universal Banking, 13 CATO J. 289 (1993) (describing the salient characteristics of German and Swiss universal banking, the different legislative environment in the United States in 1993, and the arguments for and against universal banking).

${ }^{60}$ TCH BANK ECONOMICS, supra note 52, at 6.

${ }^{61} I d$.

${ }^{62}$ See Fed, Assets and Liabilities of Commercial Banks in the United States (Weekly)-H.8, BOARD Governors FED. ReS. Sys. (April 13, 2012), http://www.federalreserve.gov/releases/h8/current/ (providing the total assets as of December 31, 2011); Top 50 BHCs, NAT'L INFO. CENTER (Mar. $31, \quad 2012$ ), http://www.ffiec.gov/nicpubweb/nicweb/Top50Form.aspx (providing the total assets of the four U.S. universal banks). 


\section{Retail and Commercial Banks}

Retail and commercial banks tend to represent "traditional" banking of the kind that usually comes to mind when the term "bank" is used in popular parlance. They usually have an extensive physical or "branch" presence, providing both in-person banking services and online equivalents, and they usually have large ATM networks. ${ }^{63}$ In the United States, apart from the four universal banks listed above, twenty such institutions have total assets of over $\$ 50$ billion each. $^{64}$

\section{Investment Banks}

Investment banks specialize in the capital markets. ${ }^{65}$ They have traditionally represented Wall Street, and for decades the GlassSteagall Act kept them separate from traditional retail and commercial banking. As a result of the failure of some of the leading investment banks during the Crisis, ${ }^{66}$ only two major investment banks remain: Goldman Sachs and Morgan Stanley. ${ }^{67}$ Even these two institutions are now bank holding companies. ${ }^{68}$

\section{Investment Servicers and Managers}

These institutions provide custodial and other services to banks, investment houses, brokerages and various other more specialized financial institutions. ${ }^{69}$ Bank of New York Mellon, State

${ }^{63}$ TCH BANK ECONOMICS, supra note 52, at 17.

${ }^{64} \mathrm{Id}$. at 7.

${ }^{65} \mathrm{Id}$. at 7.

${ }^{66}$ During which Bear Stearns collapsed and was absorbed by JP Morgan; Lehman Brothers filed for bankruptcy; and Merrill was absorbed by BofA.

67 See TCH BANK ECONOMICS, supra note 52, at 7 (stating that Goldman and Morgan Stanley are the only investment banks with more than $\$ 50$ billion in assets).

${ }^{68}$ See, e.g., Michael J. de la Merced et al., As Goldman and Morgan Shift, a Wall St. Era Ends, N.Y. Times DeALB\%K (Sept. 21, 2008, 9:35 PM), http://dealbook.nytimes.com/2008/09/21/goldman-morgan-to-become-bankholding-companies (discussing the industry significance of these two iconic investment banks becoming bank holding companies).

${ }^{69}$ See TCH BANK ECONOMICS, supra note 52, at 7 (stating that investment services and managers as "are uniquely at scale in the payments \& clearing space"). 
Street and Northern Trust are the three very large institutions (total assets over $\$ 500$ billion each) that are also headquartered in the United States. $^{70}$

In addition to these four major "categories," a number of important qualifying observations should be added. First, many other financial institutions are very large in particular areas of financial services but not in others. ${ }^{71}$ Some banks are extremely large in certain areas of "banking," while others are very large in all arenas. It is universal banks that attract the most concern because of their diversity and interconnectedness. More specialized institutions, however, also have enormous implications for overall financial stability, as the near collapse of AIG, technically an insurance company, illustrated during the Crisis.

Second, "banks" come in many forms and permutations. Regulators have treated bank holding companies with total assets greater than $\$ 1$ billion as "large complex financial institutions" ("LCFIs"), indicating their need for special and increasingly enhanced forms of regulation. ${ }^{72}$

${ }^{70} I d$.

71 "Standalone" credit card, brokerage and insurance companies are examples. To illustrate, Capital One, a credit card company, had \$206 billion in total assets as of Dec. 31, 2011, which ranked it as the fourteenth largest bank holding company in the United States. Top 50 Bank Holding Companies, NATIONAL INFORMATION CENTER, http://www.ffiec.gov/ nicpubweb/nicweb/top50form.aspx (last visited Mar. 13, 2012). It has subsequently grown larger as a result of acquisitions. In February 2012, Capital One completed its acquisition of ING Direct and is now a more diversified bank with total consolidated assets of almost $\$ 290$ billion. Press Release, Capital One Completes Acquisition of ING Direct (Feb. 17, 2012), available at http://phx.corporate-ir.net/phoenix. zhtml?c=70667\&p=irolnewsArticle \&ID=1662485\&highlight.

${ }^{72}$ The Fed, for example, defines LCFIs to include all "big banks" as well as a much broader range of "complex" institutions ranging to as low as one billion dollars in assets. See Lisa M. DeFerrari \& David E. Palmer, Supervision of Large Complex Banking Organizations, 87 FED RES. BuLL. 47, 51 (2001) (describing the program for "risk-focused supervision - the program that the Fed applies to all complex banking organizations with more than \$1 billion in assets"). LCFIs are treated separately from other financial institutions because they combine a number of widely diverse financial businesses and therefore produce much more complex risk profiles and require unusually complex oversight. See id. at 50 (describing the Fed's supervision of LCFIs). 
Third, there is a vast "infrastructure" of financial institutions that makes modern banking possible, including what are referred to as "financial market utilities"" and other exchanges. Such institutions range from stock, commodities and derivatives exchanges to individual companies providing financial instruments for risk management, such as credit default swaps, to investment vehicles such as hedge funds and mutual funds. ${ }^{74}$ This aspect of financial services is often referred to as the "shadow banking industry," 75 and it is often mistakenly treated as an unregulated parallel to the banking industry itself. In fact, this industry is more accurately understood as part of the overall financial ecology within which all large financial institutions operate in various, highly connected ways. ${ }^{76}$

Finally, a number of very large foreign financial institutions have a major presence in the United States and are in direct competition with U.S. banks. ${ }^{77}$ Many of these are among the largest banks in the world. ${ }^{78}$ So when we consider "big banks," any discussion of their value, costs and threats to

${ }^{73}$ See Dodd-Frank Act, Pub. L. 111-203, § 804(a)(2), 124 Stat.1376, 1807 (2010) (to be codified at 12 U.S.C. $\S 5463(a)(2)$ ) (establishing the standards for regulating financial market utilities); $i d$. $\S 803(6)$ (to be codified at 12 U.S.C. § 5462(6)) (defining "financial market utility"). See generally Anna L. Paulson \& Kirstin E. Wells, Enhancing financial stability: The case of financial market utilities, CHICAGO FED LETTER, no. 279, 2010 (discussing the provisions of the Dodd-Frank Act related to financial market utilities).

${ }^{74}$ On hedge funds and mutual funds, see Taub, supra note 27, at 198-203 (discussing the role hedge funds played in the financial crisis).

${ }^{75}$ See generally Zoltan Pozsar ET AL., Fed. Reserve BANK OF N.Y., StAFF REPORT No. 458, SHADOW BANKING (2010), available at http://www.newyorkfed.org/research/staff_reports/sr458.pdf (discussing the features of the shadow banking industry and analyzing the industry's relationship with the traditional banking system).

${ }^{76}$ See infra text accompanying note 326.

${ }^{77}$ See infra text accompanying note 138.

${ }^{78}$ For example, as of December 31, 2011, Taunus Corporation - a subsidiary of Deutsche, the largest bank in the world (by assets) - was the eighth largest bank in the United States. The subsidiaries of HSBC, the third largest bank in the world, were tenth largest in the United States. See Top Banks in the World 2011, BANKS AROUND THE WORLD, http://www.relbanks.com/worlds-top-banks/assets-2011 (last visited Mar. 14, 2012) (listing the world's largest bank holding companies); Top 50 Bank Holding Companies, supra note 71 (listing the largest banks including their subsidiaries). 
financial stability tends also to be relevant to these massive foreign banks.

\section{Value of Big Banks}

Big bank executives insist that there is considerable advantage to growing the size of their institutions. A number of reasons are offered. First, size enables banks to capture efficiencies of scale $^{79}$ and, with the right business mixes, efficiencies of scope. ${ }^{80}$ This is probably the most frequently advanced defense of big banks, particularly the complex business combinations that comprise universal banks. ${ }^{81}$ Second, it is argued that modern global banking services require large-scale capacity in order to deliver products and innovations that smaller banks could not do effectively. ${ }^{82}$ Third, it

${ }^{79}$ Economies of scale result from the ability to leverage a business across greater numbers of customers or greater firm infrastructure, thereby reducing the unit cost of services and increasing profits. See TCH BANK ECONOMICS, supra note 52, at 8-9 ("Large banks reduce unit costs by spreading fixed costs, particularly for infrastructure and technology, over a large customer base.").

${ }^{80}$ Economies of scope are those that can be secured as a result of the combination of businesses. In other words, being able to run one business in combination with another generates synergies. See CANALS, supra note 59 at 103 .

81 Jamie Dimon, the CEO of JP Morgan, has crisply stated the case for greater size, voiced by many of his counterparts:

"Companies come in various sizes, shapes and forms. There are many reasons for this. At JPMorgan Chase, we benefit from huge economies of scale in our businesses. The same goes for most large enterprises. Economies of scale in our industry generally come from technology, including data centers, networks and software; the benefits of global branding; the ability to make huge investments; and the true diversification of risks. The beneficiaries of these economies of scale ultimately are the consumers who these companies serve."

JPMORGAN CHASE \& CO., 2010 ANNUAL REPORT 30 (2011), available at http://investor.shareholder.com/jpmorganchase/ annual.cfm (follow "2010 Complete Annual Report” hyperlink).

${ }^{82}$ See TCH BANK ECONOMICS, supra note 52, at 8 (describing innovation as one of large banks' "unique benefits"). 
follows from the first two arguments in favor of big banks that U.S. banks would need to be large enough to be competitive internationally. ${ }^{83}$ Finally, when one observes the use by government of big banks, it becomes evident that big banks are, in effect, critical instrumentalities of the state. ${ }^{84}$

\section{Efficiency}

Numerous studies have attempted to measure the effects of size and business diversification on the efficiency of big banks. Notwithstanding a considerable body of literature, neither side of the simple "efficiencies" argument is conclusive. Indeed, measuring both competitive performance and efficiencies is an exceptionally difficult empirical exercise in which there may never be clear answers, for a variety of reasons. ${ }^{85}$

In the first place, the very idea of "efficiency" itself is problematic because it must be assessed in a dynamically changing environment. ${ }^{86}$ The criteria for measuring efficiencies are various and sometimes not easily measurable. The range of variables is also very broad, such as certain types of finance in different regions, domestic as opposed to transnational, and so on. Relative stages of development of both technology and managerial skill are important. The permutations of business mix also vary substantially from bank to bank, and universal banks reach for a combination of efficiencies of scale and scope.

Second, most of the efficiency studies addressed a time when financial institutions were much smaller than they are now. Even more recent studies tend to close out their data before the financial collapses during the Crisis; in doing so they fail to account for huge delayed but very real costs that should be charged against the

${ }^{83}$ See JPMORGAN CHASE \& Co., supra note 81, at 30-31 (highlighting the need for American banks to be competitive globally).

${ }^{84}$ See infra note 193, and accompanying text (providing nineteenth century cases in which courts described banks as instrumentalities of the state).

${ }^{85}$ For a sophisticated framing of this task, see SAUNDERS \& WALTERS, supra note 59 , at ch. 2 .

${ }^{86}$ See id. at 17. The authors note that "[d]ynamic efficiency is characterized by high rates of financial product and process innovation through time." Id. This emphasizes the potential validity of claims that, while efficiencies have not yet been captured, the universal bank model, once mastered, will indeed capture great efficiencies of scale and scope. 
benefits such institutions appeared to provide before things went wrong.

Finally, big banks enjoy the benefit of massive public subsidies that come in various forms: access to central bank reserves, underpriced deposit guarantees, tax subsidies and, most controversial of all, the subsidy derived from being perceived in the marketplace as "too-big-to-fail" and the accompanying implicit guarantee of government support should they encounter difficulties. Thus, the "efficiencies" that ultra-large banks generate should be weighed against the public support that they receive.

\section{i. Rapidly Seeking Efficiency}

Modern American universal banks and their foreign counterparts ${ }^{87}$ represent financial versions of the great industrial conglomerates of the twentieth century, such as Du Pont, IBM, Standard Oil (now Exxon), British Petroleum, General Motors and General Electric. In the United States and elsewhere, such diversified conglomerates have represented some great economic triumphs, contributing to the development and refinement of what has been called the "modern multiunit business enterprise." powered by, and also have created, huge potential markets and, in the United States, the largest economy in the world. In the process, they have formed a sophisticated system of "competitive managerial

\footnotetext{
${ }^{87}$ There are and have been major differences in the structures, funding and business modes of European, British, Japanese and American universal banks. Their common characteristic, however, is that they assemble a diverse range of businesses from various financial (and even non-financial) sectors within a corporate conglomerate. See CANALS, supra note 59, at chs. 6-8 (discussing the German, Japanese and Spanish models); SAUNDERS \& WALTERS, supra note 59, at ch. 4 (discussing the German, Swiss and U.K. models). The history of the rise of universal banks in the United States has been well documented. See generally Arthur E. Wilmarth, Jr., The Transformation of the U.S. Financial Services Industry 1975 - 2000: Competition, Consolidation, and Increased Risks, 2002 U. ILL. L. REV. 215 (2002).

88 Alfred D. Chandler, JR., The Visible Hand: The Managerial Revolution in American Business 6 (1977) [hereinafter The Visible HAND].
} 
capitalism" on a grand scale. ${ }^{89}$ Such organizations succeeded by capturing economies of scale and scope that have reduced unit costs, made products more affordable and provided the space to make them better. They have refined production and distribution and developed managerial infrastructures capable of coordinating the complexity of these emerging industrial giants. ${ }^{90}$

Yet the great conglomerates have not automatically delivered the rewards of their supposed efficiency. ${ }^{91}$ Indeed, many of these conglomerates have destroyed billions of dollars in shareholder

89 See generally Alfred D. Chandler, JR., ScAle AND Scope: The DYNAMICS OF INDUSTRIAL CAPITALISM 84-89 (1990) [hereinafter SCALE AND SCOPE].

90 The classic studies on the rise of competitive managerial capitalism in American history are by the late Alfred D. Chandler, Jr. See generally SCAlE AND SCOPE, supra note 89; Alfred D. ChANDleR, JR., STRATEGY AND STRUCTURE: CHAPTERS IN THE HISTORY OF THE INDUSTRIAL ENTERPRISE (1969); THE VISIBLE HAND, supra note 88.

${ }^{91}$ See, e.g.,. In Professor Jim Collins' Good to Great: Why Some Companies Make the Leap . . . And Others Don't, the author expresses considerable skepticism about diversified conglomerates, stating that "[o]ur study strongly suggests that highly diversified firms and conglomerates will rarely produce great results." JiM COLLINS. GOOD TO GREAT: WhY SOME COMPANIES MAKE THE LEAP . . A AND OTHERs DON'T 215 (2001). Professor Collins continues, "One obvious exception to this is GE, but we can explain this case by suggesting that GE has a very unusual and subtle Hedgehog Concept [i.e. single focused vision] that unifies its agglomeration of enterprises. What can GE do better than any company in the world? Develop first-rate general managers." Id. It should be added that Good to Great was written before GE experienced a major collapse in its market value, a collapse from which it has struggled to recover. It is important to focus on this "Hedgehog Concept": Professor Collins attributed GE's success to its ability to avoid mingling its businesses, instead running them as separate enterprises. See id. at 216 ("GE's Hedgehog Concept, properly conceived, enables the company to operate in a diverse set of businesses yet remain squarely focused on the intersection of the three circles."). This caution has direct connotations for universal banks, which are rationalized as creating "synergies" between their various businesses but also more complex management challenges. See infra text accompanying notes 119126 (discussing problems a corporation may encounter when merging businesses). Sadly, GE ranked as the world's third biggest "destroyer" of shareholder value for the period between 1993 and 2010. PABLO FERNANDEZ ET AL., SHAREHOLdER VAlUE CREATORS IN THE S\&P 500: 1991-2010, at 5 (2011), available at http://papers.ssrn.com/sol3/ papers.cfm?abstract_id=1759353. 
capital, ${ }^{92}$ including some American universal banks. ${ }^{93}$ Furthermore, the track record of these relatively new institutions remains short, perhaps too short to draw any firm conclusions about the viability of their business models for sustained performance.

To understand the difficulties big banks face in attaining efficiencies of scale and scope, three important factors influencing the development of modern big banks should be kept in mind: ${ }^{94}$ longstanding restrictions on growth and diversification; sudden elimination of these restrictions; and the very recent and escalating intensity of competition and risk that has come to dominate the environment within which growth has taken place.

First, modern big banks, particularly universal banks, experienced a kind of arrested development because of various impediments to their growth. Economies of scale were inhibited as a result of strict geographic restrictions that confined banks to specific cities, regions or states and prevented banks from building significant scale except as money center banks in cities such as New York and Chicago. ${ }^{95}$ Economies of scope were obstructed by other restrictions: The Glass-Steagall Act of 1933 forced a separation between investment and commercial banking, ${ }^{96}$ and the Bank Holding

${ }^{92}$ Americans are remarkably tolerant of such blatant corporate failure. See ThOMAS K. MCCRAW, AMERICAN Business SinCE 1920: How IT WORKED 253 (2d ed. 2009) ("Americans were also more forgiving of failure . . . and they were remarkably tolerant of bankruptcy ... in America [bankruptcy] was often regarded as a phase through which entrepreneurs routinely passed on their way to eventual riches.").

${ }^{93}$ See Fernandez ET AL., supra note 91. at 5 (describing Citi, BofA and Merrill as shareholder value destroyers).

${ }^{94}$ This article focuses only on the particular factors affecting the growth of big banks in the United States.

${ }^{95}$ These restrictions were imposed primarily via the McFadden Act of 1927 , Pub. L. No. 69-630, § 7, 44 Stat. 1224, 1228 (codified as amended at 12 U.S.C. § 36(c) (2006)), which required nationally chartered banks to observe state-based restrictions on intrastate banking, and the Bank Holding Company Act of 1956, Pub. L. No. 511, § 3(d), 70 Stat. 133, 135 (codified as amended at 12 U.S.C. $\S 1842(\mathrm{~d})(1)(\mathrm{A})$ ), which required bank holding companies to observe state-based restrictions on entry and further expansion.

${ }^{96}$ See Glass-Steagall Act of 1933, Pub. L. No. 73-66, § 20, 48 Stat. 162, 188, repealed by Gramm-Leach-Bliley Financial Modernization Act of 1999, Pub. L. No. 106-102, § 101(a), 113 Stat. 1338, 1341. To be sure, nascent universal banks, such as JP Morgan \& Co., had existed early in the twentieth century, but the impact of the Glass-Steagall Act was to break up 
Company Act of 1956 forced a separation of banking and commerce. $^{97}$

For many decades, banks had also been restricted geographically. ${ }^{98}$ From the late 1980 s to the mid to late 1990 s, the geographic restrictions on banks, as well as the walls between investment and commercial banking and between banking and insurance, were dismantled through a combination of state compacts, ${ }^{99}$ regulatory action ${ }^{100}$ and congressional ${ }^{101}$ action. $^{102}$ Until

such combinations. CANALS, supra note 59, at 95. Also, Chase Manhattan Bank, a predecessor bank in the formation of today's JP Morgan Chase, followed a universal banking strategy that covered all segments of the financial industry from its founding in 1877. Id. at 84-88.

${ }^{97}$ See Bank Holding Company Act of 1956 \& 4(a) (codified as amended at 12 U.S.C. § 1843(a) (2006)) (stating that "no bank holding company shall . . . acquire direct or indirect ownership or control of any voting shares of any company which is not a bank").

${ }^{98}$ This factor accounts for the huge number of banks in the United States when contrasted with other countries. Precisely because of geographic segmentation, however, large aggregate numbers of banks does not necessarily imply highly competitive local markets. Bank antitrust law has long been considered an important factor in evaluating bank mergers, and antitrust analysis must focus on discreet geographic sections of the country rather than the country as a whole. See, e.g., United States v. Conn. Nat'l Bank, 418 U.S. 656, 666-70 (1974) (discussing "section of the country" analysis as required by 12 U.S.C. § 1828 (2006)); United States v. Phila. Nat'l Bank, 374 U.S. 321, 360-62 (1963) (finding the relevant geographical market to be a four county area).

${ }^{99}$ Various states formed regional compacts permitting their banks to extend operations into adjacent states. The constitutionality of these compacts was upheld in Northeast Bancorp v. Bd. of Governors of the Fed. Reserve Sys., 472 U.S. 159 (1985), triggering a number of banking combinations and the beginning of consolidation in the U.S. banking industry.

${ }^{100}$ National banks were able to breach geographic restrictions in small ways by relying on a generous OCC interpretation of a statute that permitted banks to move their headquarters across state lines if the new location remained within thirty miles of the old headquarters. See, e.g., Synovous Fin. Corp. v. Bd. of Governors of the Fed. Reserve Sys., 952 F.2d 426, 428 n.1 (D.C. Cir. 1991) (noting the OCC's statutory interpretation that banks could relocate within a thirty mile radius regardless of state); see generally 12 U.S.C. § 30(b) (2006). The OCC also permitted national banks to enter the insurance agency business if they located the headquarters of the insurance agency in a town with less than 5000 inhabitants. See Barnett Bank of Marion County, N.A. v. Nelson, 517 U.S. 25, $37-38$ (1996) (finding 
this deregulatory process was largely complete, however, U.S. banks remained relatively small or highly specialized. ${ }^{103}$

Second, once restrictions were lifted, America's contemporary big banks grew rapidly, almost precipitously, within a turbulent merger environment. The barriers to universal banking combinations finally gave way in the United States at the end of the twentieth century. This in turn triggered a precipitous series of combinations and consolidations, at a pace never before witnessed. The universal banking model appeared extremely attractive to American bankers, who were also concerned that without such a model they could not meet the demands of global competition, ${ }^{104}$ and

that the National Bank Act pre-empted Florida state law prohibiting national banks from engaging in the insurance business).

${ }^{101}$ The first important statute was the Riegle-Neal Interstate Banking and Branching Efficiency Act ("Riegle-Neal"), Pub. L. 103-328, 108 Stat. 2338 (1994) (codified as amended in sections of 12 U.S.C.), which facilitated nationwide banking through separate subsidiaries and, in most cases, branching. The second was the Gramm-Leach-Bliley Financial Modernization Act of 1999, Pub. L. No. 106-102, 113 Stat. 1338 ("GrammLeach-Bliley") (codified as amended in sections of 12 U.S.C.), which repealed Glass-Steagall. See id. § 101(a) ("Section 20 of the Banking Act of 1933 ... (commonly referred to as the 'Glass-Steagall Act') is repealed."). For various perspectives on the impact of the Gramm-Leach-Bliley Act, see, e.g., James R. Barth et al., The Repeal of Glass-Steagall and the Advent of Broad Banking, 14 J. ECON. PERSP. 191 (2000); Jonathan R. Macey, The Business of Banking: Before and After Gramm-Leach-Bliley, 25 J. CORP. L. 691 (2000).

102 It should also be noted that banks that had acquired failing federal savings and loan associations as part of the resolution of the Savings and Loan Crisis of the late 1980s and early 1990s were permitted by the Office of Thrift Supervision to take advantage of the fact that those associations had been permitted to branch nationwide. See, e.g., Conference of State Bank Supervisors v. Office of Thrift Supervision, 792 F. Supp. 837, 845 (D.D.C. 1992) (addressing and upholding this interpretation).

${ }^{103}$ For example, the total consolidated assets of Citi on Dec. 31, 1996, were \$281 billion, a little more than a tenth of the size Citi had reached by 2008. See generally Citicorp, Annual Report (Form 10-K) (Feb. 28, 1997), available at http://www.sec.gov/Archives/edgar/data/20405/000095013097-000720.txt.

${ }^{104}$ See, e.g., Edward Harrison, How Globalization Led to Universal Banking in America, SeEKING AlPHA (Jul. 13, 2009), http://seekingalpha. com/article/148433-how-globalization-led-to-universal-banking-in-america. Mr. Harrison states that: 
their academic supporters. ${ }^{105}$ A series of regulatory rulings had partly opened the way for combining banking and insurance, ${ }^{106}$ banking and securities brokerage, and commercial banking and investment banking. ${ }^{107}$

By the 1990s, the now internationalised European universal banks were on the prowl in America too (I am ignoring Japan because its banks were forced into retreat during the lost decade). We saw Credit Suisse (CS) acquire First Boston, SBC acquire Dillon Read, and Deutsche Bank (DB) acquire Bankers Trust. Now we were seeing international universal bank behemoths that had huge balance sheets and huge investment banking and trading operations in America. The American companies felt at a disadvantage because of Glass-Steagall. And, in truth, they were. So, at this point, Glass-Steagall's repeal was inevitable because the climate in banking had changed. It was much more international and much more of a universal banking model.

Id.

${ }^{105}$ The discussions regarding universal banking in the United States made specific reference to the supposed advantages enjoyed by foreign universal banks. See, e.g., Charles W. Calomiris, U.S. Bank Deregulation in Historical PersPeCtive 267 (2000) ("The Clayton Act of 1914 may have further hampered America's ability to develop universal banking, by limiting bankers' influence over client firms through interlocking boards of directors . . . Consistent with the argument that economies of scope in universal banking are enhanced by large-scale banking, the dramatic increase in bank involvement in securities markets in the 1920s coincided with a dramatic increase in consolidation and branching by banks."). For a more conservative analysis, see SAUNDERS \& WALTER, supra note 59, at 49 ("The United States is virtually alone as a nation where these discussions have traditionally relegated international competitive consequences to a subordinate position . . . An optimal domestic regulatory structure must therefore be designed with a view to actual and prospective financial globalization.").

${ }_{106}$ See, e.g., Wilmarth, supra note 87, at 218-21 ("The FRB approved the Citicorp-Travelers merger even though the proposal "challenge[d] both the statutory letter and regulatory spirit" of existing law and Congress had not yet acted on pending financial modernization bills.").

${ }_{107}$ See id. at 316-21 ("During the past several years, the largest U.S. banks have rapidly expanded their involvement in higher-risk activities such as underwriting and dealing in securities and derivatives, leveraged syndicated lending to domestic and foreign customers, and securitized consumer 
Indeed, by 1997, the historical restrictions lay in tatters, turning some banks into de facto universal banks. ${ }^{108}$ The all-butinevitable repeal of Glass-Steagall was precipitated by a dramatic announcement in April 1998 of a then-still-illegal merger between Travelers Group (a major insurance conglomerate) and Citicorp (a traditional banking conglomerate but one that had begun to diversify into nontraditional areas). ${ }^{109}$ Faced with the fait accompli of this new American universal bank, Congress passed and President Clinton signed into law the Gramm-Leach-Bliley Act ("Gramm-LeachBliley") in 1999. ${ }^{110}$ Notwithstanding grave misgivings on the part of many legislators, ${ }^{111}$ many industry leaders and politicians on both sides of the aisle ${ }^{112}$ trumpeted the enactment of Gramm-Leach-Bliley as heralding a new era in modern banking. ${ }^{113}$

lending to subprime borrowers."); Jerry W. Markham, Banking Regulation: Its History and Future, 4 N.C. BANKING INST. 221, 248-52 (2000) (summarizing the expansion of banks into an array of financial services and products, with regulatory approval). For a thorough regulatory review of the steps toward deregulation during the critical time period between the 1980s and mid-1990s, see 1 FDIC Div. Res. \& STATS, An EXAMINATION OF THE BANKING CRISES OF THE 1980S AND EARLY 1990s, at ch. 2 (1997), available at $\mathrm{http}: / / \mathrm{www}$. fdic.gov/bank/historical/history/87_136.pdf.

${ }^{108}$ See, e.g., Note, The New American Universal Bank, $11 \overline{0}$ HARV. L. REV. 1310 (1997) (describing the path to universal banking through a combination of regulatory reinterpretations of otherwise restrictive banking laws).

${ }^{109}$ See infra text accompanying note 119.

${ }^{110}$ Gramm-Leach-Bliley Act, Pub. L. No. 106-102, 113 Stat. 1338 (1999) (codified as amended in sections of 12 U.S.C.).

${ }^{111}$ See, e.g., Dean Anason, Senate Passes Reform Bill; Gramm Calls for a Sequel, AM. BANKER, Nov. 5, 1999, at 1 (quoting Senator Paul Wellstone as warning that repeal of the Glass-Steagall Act would "accelerat[e] the trend toward massive consolidation of the financial sector," was "the wrong kind of modernization," that "Americans could be hurt both as consumers and taxpayers" and that "[w]e seem determined to unlearn the lessons from our past mistakes ... . Today's lust for global gigantism has swept aside the voices of prudence;" and quoting Senator Paul Sarbanes, the Senate Banking Committee's ranking Democrat, as warning that Congress would eventually have to confront institutions that would become "too big to fail").

${ }^{112}$ See id. (quoting Senator Phil Gramm, chairman of the Senate Banking Committee, as hailing the Gramm-Leach-Bliley Act's passage and calling for the repeal of the division between banking and commerce); President William Clinton, Remarks on Signing the Gramm-Leach-Bliley Act (Nov. 12,1999 ) ("It is true that the Glass-Steagall law is no longer appropriate to 
Thus, by 1999, American universal banking had emerged, driven by the optimistic pursuit of economic efficiency, profits and a renewed sense of international competitiveness. A major change in the structure of U.S. financial services organizations quickly took place. This was shaped by a series of "mega-mergers" across the various sectors of the financial industry. ${ }^{114}$ Within a few short and hectic years-from 1997 to 2001-there emerged a number of nascent, yet soon huge, full-fledged universal banks. ${ }^{115}$ In the subsequent convolutions of the Crisis, new consolidation took place, ${ }^{116}$ bringing the U.S. financial services industry to the point

the economy in which we live. It worked pretty well for the industrial economy ... . . But the world is very different. ... [The repeal of GlassSteagall] shows what can happen when republicans and Democrats work together...").

${ }^{113}$ For a retrospective evaluation of the merits of the Gramm-Leach-Bliley Act in light of the Financial Crisis, see, e.g., Wilmarth, supra note 87; Jerry W. Markham, The Subprime Crisis-A Test Match for the Bankers: GlassSteagall vs. Gramm-Leach-Bliley, 12 U. PENN. J. Bus. L. 1081 (2010); Lawrence J. White, The Gramm-Leach-Bliley Act of 1999: A Bridge Too Far? Or Not Far Enough?, 43 SufF. L. Rev. 937 (2010).

114 See Robert DeYoung et al., Mergers and Acquisitions of Financial Institutions: A Review of the Post-2000 Literature, 36 J. FIN. SERVICES RES. 87, 89-90 figs. 1-3 (2009) (charting the rapid intrasectoral consolidation of U.S. banks, insurance companies and securities companies, particularly during the 1997 - 2001 era).

${ }^{115}$ See id. at 90-92 figs. 3-5 (charting the spike in cross-sector financial firm consolidation).

${ }^{116}$ The largest new combinations during 2008 in the United States were:

1) JP Morgan Chase, which absorbed Bear Sterns and Washington Mutual (growing from almost $\$ 1.6$ trillion in total assets at Dec. 31,2007 , to almost $\$ 2.3$ trillion by Sept. 30, 2008);

2) BofA, which absorbed Countrywide Financial and Merrill (growing from $\$ 1.7$ trillion at Dec. 31,2007 , to $\$ 2.2$ trillion by Dec. 31, 2008 (pro forma including Merrill Acquisition)); and 3) Wells, which absorbed Wachovia (growing from $\$ 575$ billion at Dec. 31, 2007, to $\$ 1.3$ trillion at Dec. 31, 2008).

See JPMorgan Chase, Form 10-Q (Form 10-Q) (Nov. 7, 2008) (listing total assets of approximately $\$ 2.3$ trillion dollars at Sept. 30, 2008, compared with approximately $\$ 1.6$ trillion dollars at Dec. 31, 2007); Bank of America, Form 10-Q (Form 10-Q) (Nov. 11, 2008) (listing total assets of approximately $\$ 1.7$ trillion as of Dec. 31, 2007); BANK OF AMERICA, 2009 ANNUAL REPORT 34 (2010) (stating that the bank's total assets had 
where the largest three financial institutions now own forty-four percent of the U.S. domestic market by assets and each ranks within the top ten in the world. ${ }^{117}$

This rapid consolidation has had important consequences for the risk profiles these new combinations have generated and their ability to procure the efficiencies they have promised. The repeal of the Glass-Steagall Act was itself precipitated by a massive combination that ultimately turned out to be disastrous. This was the merger of Travelers Group and Citicorp to form the new conglomerate, Citigroup. The combination collapsed acrimoniously only four years after its creation. The co-CEO of the ill-fated combination, John Reed, believes the merger "created a monster." 118 He blamed clashes of culture, while his co-CEO, Sandy Weil, blamed the failure on "very poor management and management decisions." 119

Another current example is Bank of America. ${ }^{120}$ Bank of America's coast-to-coast franchise was secured by a 1998 "merger of

increased to $\$ 2.2$ trillion, an increase that was "primarily attributable to the acquisition of Merrill Lynch"); WELLS FARGO \& CO., TOGETHER WE'LL GO FAR: Wells FARGo \& Co. ANNUAL Report 2008, at 87 (2009) (listing assets of $\$ 1.3$ trillion at Dec. 31, 2008, compared with $\$ 575$ billion at Dec. 31, 2007).

${ }_{117}$ See Mike Alberti, The 29 banks that are too big to fail-how big are they?, REMAPPING DeBATE (November 16, 2011), http://www. remappingdebate.org/map-data-tool/aftermath-2008-economic-collapsebiggest-global-banks-stillreally-big.

${ }_{118}$ Rob Blackwell et al., Older and Wiser, AM. BANKER, Feb 8, 2010, at 3.

119 For a general review of the collapse of the Travelers Group-Citi combination, see, e.g., Eric Dash, A Stormy Decade Since Travelers Merger, N.Y. TIMES (Apr. 3, 2008), http://www.nytimes.com/2008/ 04/03/business/03citi.html. The Co-Ceo of the ill-fated Citi combination, John Reed, now believes the combination "created a monster." Rob Blackwell et al., supra note 118; see also Francesco Guerrera, Merger That Created Citigroup Was a Mistake, Says Ex-Chief, Fin. TiMES, Apr. 4, 2008, at 1 (reporting on Mr. Reed's views of the dangers of trying to combine disparate cultures). Mr. Reed's partner in the merger, Sandy Weil, on the other hand, is reported to blame the failure of the merger on "very poor management and management decisions." Id.

${ }^{120}$ For a general history of the competitive growth in Charlotte of its two major banks, BofA and Wachovia, see RicK ROTHAKER, BANKTOWN: THE Rise AND Struggles of Charlotte's Big Banks (2010). The thumbnail outline in the text here is but a glimpse of a helter-skelter process involving acquisitions by each of the big banks. 
equals" between Nationsbank of Charlotte, N.C., and San Francisco's Bank of America. This combination soon ran into trouble itself when it was revealed that losses being suffered by Bank of America were far greater than Nationsbank had expected. The San Francisco leader was quickly ousted, and the combined company came to be headed and operated out of Charlotte. After a period of stabilization, the new Bank of America went on a massive acquisition spree, gobbling up Fleet Boston (2004), MBNA (2005), La Salle Bank and US Trust Corp. (2007), Countrywide (2008) and Merrill Lynch (2008-2009). The latter acquisitions (Countrywide and Merrill Lynch) have proven near-death experiences for Bank of America, and, although the combined company rocketed to number one by assets in the United States (until it was later eclipsed by JP Morgan as its assets shrank amid large losses), the huge universal bank remains in perilous capital condition despite massive government assistance. It has suffered such massive losses that the company's stock price collapsed from $\$ 50.64$ per share at close on October 1, 2007, to $\$ 5.56$ at close of December 31, 2011, after dropping as low as $\$ 3.00$ on March 6, 2009. ${ }^{121}$ The company is an object of public demands that it be broken into smaller units. ${ }^{122}$

Plenty of other struggling or failed mergers litter the wake of this massive consolidation spree, ${ }^{123}$ and some of these combinations

121 Bank of America (BAC), YAHOO! FINANCE, http:/finance. yahoo.com/q/hp?s=BAC+Historical+Prices (last visited Apr. 4, 2012) (select a "Start Date" of Oct. 1, 2007, and an "End Date" of Dec. 31, 2011; follow "Get Prices" hyperlink).

122 See, e.g., supra note 11 and accompanying text (describing PublicCitizen's petition to break up BofA).

${ }^{123}$ The frenetic pattern is vividly demonstrated in a chart at How Banks Got Too Big To Fail, MOTHER JONES, http://motherjones.com/ politics/2010/01/bank-merger-history (last visited Apr. 4, 2012), yet even this demonstration of the helter-skelter growth and diversification experienced by the nation's leading financial institutions does not fully reflect the hundreds of acquisitions these institutions made as they pieced together their sprawling, widely diverse empires. Today's big banks are literally made up of thousands of discreet legal entities. See, e.g., FIN. STABILITY OVERSIGHT COUNCIL, 2011 ANNUAL REPORT 112 chart I.1 (2011), available at http://www.treasury.gov/initiatives/fsoc/ Documents/FSOCAR2011.pdf ("Citi and BofA have thousands of subsidiaries. Of course many of these are not operating subsidiaries, but the numbers provide some insight into the complex legal structures of these conglomerates."). 
continue to struggle. Bank of America, for example, has weathered three years since the Crisis and has been on the brink of bankruptcy. ${ }^{124}$ Citicorp has not fared much better. In the estimation of many, none of the universal banks would have survived without massive public assistance, and they still enjoy huge public subsidies.

Nor should these travails be a surprise. All kinds of hurdles have presented themselves amid continuing financial turbulence. Diverse dislocations are often the consequence of huge mergers. Indeed, these might more accurately be termed "hyper-combinations" to reflect how organizations that are not necessarily compatible either in culture ${ }^{125}$ or technology ${ }^{126}$ have been (often haphazardly) put together.

${ }^{124}$ One reaction was the submission of the petition for the breakup of BofA. See supra note 11.

${ }^{125}$ A merger can run aground on the rocks of radically conflicting cultures of commercial and investment banking. This was plainly acknowledged by John Reed when explaining the failure of the Travelers/Citicorp merger. See supra note 119. The separation of commercial and investment banking under the Glass-Steagall framework probably intensified a distinction in cultures between the two industries, with "traditional" commercial banking breeding over the six decades a fairly conservative, risk-averse culture even as investment banking encouraged a culture that ultimately "rewarded excessive risk taking and leverage." 1 Report of Anton R. Valukas, Examiner, at 3, In re Lehman Brothers Holdings Inc., No. 08-13555 (Bankr. S.D.N.Y. Mar. 11, 2010). Nicholas Dunbar has, in the author's experience, captured well the starkly different risk-taking profiles of financiers such as investment bankers and derivatives traders, on the one hand, and traditional bankers with custodial or loss-avoidance mindsets, on the other: "This rare, often admirable, but ultimately dangerous breed of financier isn't wired like the rest of us. Normal people are constitutionally, genetically, down-totheir-bones risk averse: they hate to lose money . . . . Now imagine somebody who, when confronted with uncertainty, sees not danger but opportunity . . . . This sort of person cannot be a traditional banker . . . . Such people have a very high tolerance for risk. To be more precise, they crave it. Most of us accept that risk-seeking people have an economic role to play. We need entrepreneurs and inventors. But what we don't need is for that mentality to infect the once boring and cautious job of lending and investing money." NICHOLAS DUNBAR, Introduction to THE DEVIL'S DERIVATIVES: THE UNTOLD STORY OF THE SLICK TRADERS AND HaPlesS Regulators Who Almost Blew Up Wall Street . . A And Are Ready TO Do IT AgAIN, at xii (2011).

${ }^{126}$ Much is also presumed of the ability of large combinations to leverage technology platforms. Yet hyper-combinations involve bringing together 
To be sure, a good deal of the expansion that became possible in the wake of deregulation could only be driven cost effectively through the extensive deployment of technology. Much of this deployment has proved ultimately successful, as banks exploited accounting, wire and branch automation, ${ }^{127}$ and, of course, the platform created by the Internet. But this success has come slowly and at great cost. Furthermore, the more complex systems and databases required for advanced risk management in organizations with complex risk profiles, have been slow to develop and have so far proved extremely inadequate in times of economic difficulty. ${ }^{128}$ Integrating diverse, often incompatible, databases, applications and user interfaces requires a set of exceptionally difficult tasks. ${ }^{129}$ It

multiple, diverse product lines and disparate businesses. These almost certainly run on different IT platforms, drawing off separate, self-contained and differentially coded databases that are usually highly customized for the specific products or businesses they support. Such incompatible platforms and databases either have to be run independently of each other, in which case they deliver few synergies and can even increase costs because disparate technology platforms must be made to interoperate in order to ensure that the synergies of the diverse organization can be captured, or they have to be combined through difficult conversions into single platforms that are often not designed for some of the lines of business being migrated to them.

${ }^{127}$ For example, expensive automated general ledger systems could be leveraged across a greater customer base. A bank might be able to use the same modular format for branches ("model branches") across larger geographic expanses, thereby reducing planning costs and enabling bulk contracts. One head office might supervise many more branches in new regions. Only one board of directors is needed for the system as a whole. For studies of the effects of these economies, see, e.g., Allen N. Berger \& Robert DeYoung, Technological Progress and the Geographic Expansion of the Banking Industry, 38 J. MONEY, CREDIT \& BANKING 1483 (2006); Allen L. Webster, The Impact of Technological Change on Bank Performance, 21 J. ECON. \& FIN. 41 (1997); Sherrill Shaffer \& Edmond David, Economies of superscale in commercial banking, 23 APP. ECON. 283 (1991); William C. Hunter \& Stephen G. Timme, Technical Change, Organizational Form, and Structure of Bank Production, 18 J. MONEY, CREDIT \& BANKING 152 (1986).

${ }^{128}$ See infra text accompanying notes 284-286.

${ }^{129}$ This process of sudden, jump-shift growth exacerbated already daunting challenges facing diversified large universal banks. While it is dangerous and even misleading to generalize, companies that grow organically and carefully over long periods of time tend to extend their core competencies in 
would probably not be an exaggeration to say that successful deployments in many areas of technology are still to be demonstrated.

The costs of mergers are often far greater than was estimated in pre-merger due diligence, to the extent that such due diligence even actually takes place, ${ }^{130}$ and the pressures to cut expenses can lead to counterproductive actions such as reckless outsourcing. ${ }^{131} \mathrm{~A}$

a manner that does not introduce significant new leadership and management challenges and demand the hasty acquisition of new skill sets or the wide-ranging displacement of valuable and experienced, yet suddenly cost-redundant, employees from acquisition targets. Nor does organic growth commonly introduce major cultural conflicts into the growing organization. Dominant technology platforms can often be leveraged because the existing ones are already designed for the kinds of businesses being added to the growing enterprise. See generally EDITH T. PENROSE, THE THEORY OF THE GROWTH OF THE FIRM (2009) (describing the role of organic growth in lasting organizations). Professor Penrose's work is the classic study of the limits of organic growth, the advantages of growth by merger and acquisition and the important distinction between the growth of the firm as a whole and the growth of the plant.

${ }^{130}$ In reporter Andrew Ross Sorkin's eerie but realistic account, some of the final mergers resulted from frantic notepad permutations scribbled out by the then-President of the N.Y. Fed, Timothy Geithner, as he tried to develop an overall resolution plan to avoid total financial collapse. See ANDREW Ross Sorkin, Too Big to FaIL: THE Inside StORY OF How Wall StreET AND Washington Fought to SAVE the Financial System-AND THEMSELVES 456 (2009) (describing how Mr. Geithner struggled to devise a way to save Morgan Stanley and Goldman).

${ }^{131}$ Attempts to cut expenses often drive the new combinations to outsource operations and cut headcount as much as possible. This creates further, less visible costs, such as, in the author's experience, organizational dysfunction, the loss of intellectual capital and damage to morale. See DAVID W. DeLong, Lost KNOWledge: Confronting the ThreAt of AN Aging WORKFORCE 223 (2004) ("In the past 20 years endless rounds of downsizing and reorganizations have encouraged early retirements and other departures to enable changes deemed essential by leadership (e.g., cutting costs, changing culture, pursuing new business opportunities). But these decisions have left many organizations dangerously thin in many areas of expertise."). See also Jay Jamrog, Lack of Knowledge Retention: The Hidden Cost of Corporate Downsizing, I4CP (Feb. 2, 2009), http:// www.i4cp.com/news/2009/02/02/lack-of-knowledge-retention-the-hiddencost-of-corporate-downsizing (reporting on a study by the Institute for Corporate Productivity); Charlie O. Trevor \& Anthony J. Nyberg, Keeping Your Headcount When All About You Are Losing Theirs, 51 ACAD. MGMT. 
spectacular example of the massive costs of botched outsourcing is the adoption by banks of a privately owned electronic registration system, known as the Mortgage Electronic Registration System ("MERS"), ${ }^{132}$ for originating and processing huge volumes of mortgages. ${ }^{133}$ Lawsuits arising from the adoption of MERS now pose enormous potential liability to a number of large banks. ${ }^{134}$

Third, the competition among global banks has become intense while at the same time the economic environment has become more difficult than ever. During the last decade, the consolidation of the financial industry took place in an unrelenting environment of competition, in which the compensation expectations of executives and their promises to shareholders have grown rather than diminished. Return on equity expectations are set at levels quite unrealistic given the conditions of general economic growth. ${ }^{135}$ As

J. 259 (2008) (identifying the negative consequences stemming from efficiency-drive corporate downsizing).

${ }^{132}$ See MERS, http://www.mersinc.org/ (last visited Mar. 17, 2012). For discussion of this process and its consequences, see, e.g., Michael Powell \& Gretchen Morgenson, MERS? It May Have Swallowed Your Loan, N.Y. TIMES, Mar. 6, 2011, at BU1.

${ }^{133}$ MERS offered speed and efficient management of data, yet appears to have functioned in a way that has bogged down the mortgage foreclosure process and violated the rights of mortgage holders. BofA, JP Morgan and Wells are all defendants in a major lawsuit brought by the New York Attorney General over the use of MERS. See, e.g., Chad Bray, New York Sues Banks Over Mortgage Registry System, WALL ST. J. (Feb. 3, 2012, 1:15 PM), http://professional.wsj.com/article/SB100014240529702038899 04577201060859616158.html?. See also With Foreclosure Mess, Servicers are Getting What They Paid For, U.S. BANKER, http://www. americanbanker.com//bulletins/-1026956-1.html (last visited Apr. 8, 2012) (discussing the shortcuts in mortgage servicing outsourcing that contributed to the defects on which litigation and enforcement actions are based).

${ }^{134}$ See, e.g., Cardiff Garcia, The Foreclosure Settlement, FIN. TIMES (Feb. 9, 2012, 3:08 PM), http://ftalphaville.ft.com/blog/2012/02/09/875511/theforeclosure-settlement (depicting, through a graphic description, the cost of the $\$ 25$ billion joint state-federal foreclosure settlement reached with five of the largest banks in February 2012); Letter from PublicCitizen to Ben Bernanke, supra note 11, at 11-12 (citing BofA's much larger overall potential liability for mortgage-related fraud and violations).

135 See Haldane, Control Rights (and Wrongs), supra note 6, at 12-13 (advocating for an "alternative" performance metric that reacts better to risk than RoE); Patrick Jenkins, Banks Would Profit by Taking Measures Beyond RoE, FIn. TIMES, Nov. 8, 2011, at 14 (noting how banks target 
big banks have struggled with adverse economic conditions, greater dependence on short term funding and institutional investors and the increased agency problems this dependence creates, ${ }^{136}$ and the internal challenges of securing efficiencies already described, they have resorted to leverage to secure the returns they have promised, which in turn has increased risk. ${ }^{137}$

These three considerations - the sudden opening of the floodgates, a frenetic merger environment and the changing competitive and investment environment-provide the wild panorama against which ultra-large banks have emerged. One should also remember that although big banks have existed in Europe and Asia for somewhat longer, the modern risk characteristics of most ultra large banks are relatively recent for all these organizations. As competition has become more global, universal banks around the world have come to resemble each other in many key ways, in particular regarding their funding and risk profiles. So although the focus in this section has been on American universal banks, their foreign counterparts generally also share the pressures that they are under, and most of these foreign banks compete on a large scale within the United States as well as abroad. ${ }^{138}$

RoEs that are higher than what they every achieved before the Crisis of 2008); Lawrence Baxter, The Widening Financial Gyre, TheParetoCommons (Sept. 19, 2011, TIME), http://www. theparetocommons.com/2011/09/the-widening-financial-gyre (discussing the unrealistic performance goals (fifteen to twenty percent ROE) of large financial companies in an anemic growth environment).

136 See Haldane, Control Rights (and Wrongs), supra note 6, at 9-10 (describing the impact of short-term funds and institutional investors). For a discussion on the ways in which institutional and supposedly "sophisticated" investment have diluted the impact of market discipline on financial institutions and promoted agency and corporate governance problems, creating a corresponding lack of executive accountability within financial institutions, see generally Taub, supra note 27.

${ }^{137}$ With leverage necessarily comes greater financial risk, precisely because any losses that are incurred in investment banking and trading operations must be charged against thin, highly leveraged, tiers of capital. See infra text accompanying notes 144-147.

138 "At the end of 2010, 53 member banks were operating 567 branches in foreign countries and overseas areas of the United States; 31 national banks were operating 508 of these branches, and 22 state member banks were operating the remaining 59. In addition, 18 nonmember banks were operating 26 branches in foreign countries and overseas areas of the United States . . . . As of year-end 2010, 173 foreign banks from 52 countries 


\section{ii. Elusive "Efficiency"}

The concept of "efficiency" is itself ambiguous. The efficiency of financial institutions is measured by a host of different criteria, depending on the objectives of the person conducting the measurements. In the present context "efficiency" relates to whether larger and more diversified financial institutions outperform their smaller counterparts, thus justifying the claim that bigger and more complex combinations are better, both from a profitability point of view and from the value or dangers they present society.

The traditional method of measuring the efficiency of traditional banks has been the so-called efficiency ratio, which is the ratio of expenses to revenue. ${ }^{139}$ This ratio represents the cost of producing each dollar of revenue after deducting the cost to the bank of the (theoretically uncontrollable) interest it must pay. By measuring the non-interest cost against revenue one can deduce how leanly or "efficiently" the bank operates. ${ }^{140}$ Historically a bank has been considered highly efficient if its efficiency ratio ranges below fifty percent. (In other words, the bank is able to capture fifty percent or more of total revenue, after deducting its cost of funds, as net profit before taxes.)

The efficiency ratio is not, however, the only criterion for assessing the economic success of big banks. As will be discussed, ${ }^{141}$ big bank advocates maintain that certain "big finance" undertakings require a capacity much greater than that possessed by smaller

operated 205 state-licensed branches and agencies, of which six were insured by the FDIC, and 50 OCC-licensed branches and agencies, of which four were insured by the FDIC . . . . In addition, they held a controlling interest in 55 U.S. commercial banks. Altogether, the U.S. offices of these foreign banks at the end of 2010 controlled approximately 17 percent of U.S. commercial banking assets." BD. OF GOVERNORS OF THE FED. RESERVE SYS., 97TH ANNUAL REPORT 76-78 (2011), available at http://www.federalreserve.gov/publications/annual-report/files/2010-annualreport.pdf.

${ }^{139}$ The efficiency ratio should be carefully distinguished from return on average assets and return on average equity, and it is not necessarily a measure of profitability. The significance of the ratio for investors must be determined within the overall context of business mix, degree of leverage and other factors that might well make a financial institution very profitable despite a poor efficiency ratio.

${ }^{140}$ Banks exclude net interest cost as an expense beyond their control.

${ }^{141}$ See infra text accompanying notes 176-186. 
financial institutions. ${ }^{142}$ If this is correct, then the value of such institutions would be positive even if they also displayed less favorable efficiency ratios. In addition, measuring the efficiency ratio makes most sense when banking is a margin business, in other words when the net interest margin ("NIM") is a major component of revenue. This was the case with traditional banking until recent years, particularly during the era of regulated interest rates. In recent years, however, NIM has become less significant because (1) banks, and especially universal banks, have diversified into fee-based businesses that do not rely (at least directly) on funding from deposits; and (2) we are in a period of "zero interest rate policy" ("ZIRP"), in which the effective cost of bank funding has dropped close to zero percent as a result of central bank policies designed to stimulate lending. ${ }^{143}$ At the same time, lending has remained anemic, in part because potential borrowers have been reluctant to borrow in times of great economic uncertainty, and it is difficult for banks to charge high interest rates. So NIM has shrunk considerably and revenue has to be generated through other means, principally fee income and leverage.

Scale offers another means of increasing profitability by enabling great leverage, rather than raw unit efficiency. For example, a relatively inefficient company can still generate great returns on its shareholder equity if it funds its operations via huge leverage. The leverage of banks has increased substantially over the past century, from approximately ten-to-one to as much as seventy-five-to-one or more. ${ }^{144}$ Obviously leverage also considerably increases risk of

${ }^{142}$ Capacity, that is, to provide the product or service at all, not merely at a more competitive cost.

${ }^{143}$ See, e.g., Tim Iacono, Fed Funds Rate: Turning Japanese, I Really Think So, SEEKING AlPHA (November 17, 2008), http://seekingalpha.com/article/ 106271-fed-funds-rate-turning-japanese-i-really-think-so.

${ }^{144}$ See Haldane, Control Rights (and Wrongs), supra note 6, at 6-7, 23 chart 3. By 2007 the leverage of investment banks in the United States had risen to over 20:1, and, in the case of Bear Stearns, Lehman, Merrill and Morgan Stanley, more than 30:1. Citi was running at 18:1. Sebnem Kalemli-Ozcan et al., Leverage Across Firms, Banks and Countries 40 tbl.6 (Nat'l Bureau of Econ. Research, Working Paper 17354, 2011). In the United States, the Deutsche subsidiary, Taunus, which ranks as one of the largest banks, continues to have extreme leverage (approximately 78:1). See Simon Johnson, Deutsche Bank Could Transfer Financial Contagion, BLOOMBERG (Nov. 20, 2011 TIME), http://www.bloomberg.com/news/2011-11-21/ johnson-deutsche-bank-could-transfer-contagion.html. 
failure, because the capital that backs bank operations becomes insufficient to absorb significant losses. ${ }^{145}$ Nevertheless, as long as the business does not encounter economic turbulence, leverage is a way of generating high returns on equity no matter how "inefficient" the overall bank operation might be. So, leaving questions of risk aside for the moment, ${ }^{146}$ another means of determining whether economies of scale have been captured is to measure return on common equity ("ROE"). By this criterion the stock performance of big banks with assets greater than $\$ 500$ billion was relatively good until the Crisis. ${ }^{147}$

Furthermore, a measure of ROE does not take into account the degree to which the real costs of generating profits have been externalized from shareholders to taxpayers. ${ }^{148}$ If, for example, the level of risk generated by highly leveraged operations becomes high enough to cause failure, thus requiring a taxpayer bailout, then any supposed "ROE" produced by the failing (and publicly-subsidized) institution will not reflect the full picture relating to the institution's "efficiency" or social desirability. As a result, another traditional measure of effective management, return on total assets ("ROA"), is regaining popularity. ${ }^{149}$ ROA in banking always has been very small, precisely because margins are thin. ROA is, however, at least an indicator of the productivity of a bank's investment of its funds. By this measure, the record for big banks continues to be mixed at best. ${ }^{150}$

${ }^{145}$ Inadequate capital is indeed the single most criticized aspect of big bank finance, and with good reason. Big bankers and some economists have bitterly protested efforts to impose stricter capital requirements on banks. Their arguments, however, have been thoroughly demolished by Anat R. Admati et al., Fallacies, Irrelevant Facts and Myths in the Discussion of Capital regulation: Why Bank Equity is Not Expensive (Stanford Univ. Rock Ctr. for Corporate Governance, Working Paper No. 2065, 2011), available https:/gsbapps.stanford.edu/researchpapers/library/RP2065R1\&86.pdf.

${ }_{146}$ On risks, see infra text accompanying notes 267-270.

147 Notwithstanding some early post-Crisis improvements, bank share performance has remained anemic and the long-term outlook for bank shares is poor.

${ }^{148}$ For a discussion on the public costs of large banks, see infra, Part III.

${ }^{149}$ See, e.g., Haldane, Control Rights (and Wrongs), supra note 6, at 17.

${ }^{150}$ See infra Appendix, Chart 3 (charting the return on assets for major U.S. banks). 
The second difficulty in assessing whether big banks have captured efficiencies of scale is the lack of useful empirical studies available. Some are from an era that seems quaintly archaic when compared to the massive scale of modern banks. The growth of big banks has been so recent and rapid that some of the studies are no longer meaningful. For example, as recently as 1991, one study considered "superscale" (a size at which it was assumed that banks could attain unprecedented economies of scale) to involve banks between $\$ 15$ billion and $\$ 37$ billion in total assets - a far, far cry from the $\$ 2$ trillion-plus banks of today. ${ }^{151}$ Few recent attempts to provide empirical evidence of the efficiency of today's banks are to be found, and the assertions of such efficiency are based on studies that are either irrelevant or fail to recognize important distinctions between the types of institutions that are being measured. ${ }^{152}$

This raises a third important obstacle to comparability. Building scale by extending the business over a larger customer base, perhaps through geographic extensions (entering new geographic markets, domestic and international), is a very different proposition from growing business by entering new product and service markets. While rapid increases in business volume will always tax the abilities of managers, geographic extensions of business that increase volume and rely on skills and operations already mastered is a much less complicated task than adding new lines of business or new kinds of products. Existing technology (provided that it is scalable and sufficiently sophisticated), business practices, training and welldeveloped branch and back office operations, can be leveraged to process the same kind of business over much larger customer bases. Indeed, there is some evidence to suggest that banks have been able to capture efficiencies through geographic extensions and even inmarket mergers, both domestically and internationally. ${ }^{153}$

It is different when the growth of the business evolves entry into new businesses, for example when a traditional bank acquires a brokerage, investment bank, insurance company or hedge fund. A whole new range of skills, technologies, risk profiles and even distribution networks must be acquired and mastered. Fitting the new businesses into a harmoniously functioning organization is difficult,

${ }^{151}$ See Sherrill Shaffer \& Edmond David, Economies of Superscale in Commercial Banking, 23 APPLIED ECON. 283, 283 (1991) (discussing the efficiency of "superscale" institutions).

${ }^{152}$ See infra text accompanying notes $162,172$.

${ }^{153}$ See infra text accompanying notes 157-163. 
yet this must be achieved if the merger is to succeed. There are precious few studies that focus on the kinds of genuine inter-business mergers that form the building blocks of universal banks. To the extent that profitability has been improved, it is not yet clear whether this is because of efficiencies of scale or of scope.

\section{iii. Evidence for Efficiencies of Scale}

Studies during the early stage of geographic expansion ${ }^{154}$ suggested that banks quickly exhausted such economies of scale. ${ }^{155}$ Later research, however, appeared to indicate that it would only be a matter of time until retail and commercial banks, which most needed geographic deregulation, would figure out how to develop largescale, efficient distribution across broad geographic networks. ${ }^{156}$ While rapid increases in scale will always test the abilities of managers, the geographic extension of specific businesses that managers already knew well is not insurmountably difficult and geographic consolidations (market extension mergers) appear to be realistic methods of enhancing efficiency when based on the right technology platforms. ${ }^{157}$ There is certainly anecdotal evidence that such efficiency gains may be realized. ${ }^{158}$

\footnotetext{
${ }^{154}$ See supra, note 127.

${ }^{155}$ See Shaffer \& David, supra note 151, at 292 (stating that economies of scale are not exhausted for banks between $\$ 15$ billion and $\$ 37$ billion). $C f$. David C. Wheelock \& Paul W. Wilson, New Evidence on Returns to Scale and Product Mix Among U.S. Commercial Banks, 47 J. MONETARY ECON. 653, 653-54 (2001) (finding that economies of scale are exhausted once banks reach the $\$ 300$ to $\$ 500$ million asset range, with "some" evidence that efficiencies could be attained up to the $\$ 1$ billion level).

${ }^{156}$ For a very helpful, general review of the current state of more than 150 empirical studies, see generally Robert DeYoung et al., supra note 114. But see Allen N. Berger et al., Competitive Viability in Banking: Scale, Scope, and Product Mix Economies, 20 J. Monetary ECON. 501, 502-03 (1987) (reviewing the evidence and finding it dubious as support for the view that branch networks can be extended to capture scale economies).

${ }^{157}$ Evidence relating to cross-border mergers involving market extensions also suggests that scale economies in traditional banking are also attainable, particularly if efficient banks are able to extend their operations to inefficient targets. See Donald R. Fraser \& Hao Zhang, Mergers and LongTerm Corporate Performance: Evidence from Cross-Border Bank Acquisitions, 41 J. Money, Credit \& BANKING 1503, 1503 (2009) ("We
} 
The ultimate record is mixed, however, with very large banks (assets exceeding $\$ 500$ billion) not doing nearly as well as their much smaller counterparts ( $\$ 20$ million to $\$ 100$ billion in total assets), at least until very recently. ${ }^{159}$ As far as efficiency ratios are concerned, very large banks have displayed a substantial decrease in efficiency between 2006 and the present (though this is probably due to the massive write-offs that they have had to apply in the wake of the Crisis). There is also scant evidence that they are consistently able to outperform the efficiency of banks with assets of $\$ 100$ billion or less.

The realization of such efficiencies at very large scale still appears to be a long way off. In the case of large-scale banks with average assets between $\$ 100$ billion and $\$ 500$ billion, the data suggests that banks were able to gain significant efficiencies of scale during periods in which bank consolidations could focus on refining their infrastructures and delivery systems. ${ }^{160}$ The author's research identifies an eight point improvement in the average efficiency of such banks during the period between 2000 and $2003 .{ }^{161}$ In that time, many banks that had expanded geographically and within market but remained focused on traditional banking activity were able to consolidate branches, supplement physical delivery with electronic delivery and refine back office operations. ${ }^{162}$ Indeed, banks within

find that . . cross-border acquisitions produce improved target performance.").

${ }^{158}$ See, e.g., JPMORGAN CHASE \& Co., supra note 81, at 30 ("In our retail business, buying [Washington Mutual] enabled us to improve branches in many ways: adding salespeople; retrofitting and upgrading each location; adding improved products, services and systems; and saving some $\$ 1$ million at each branch. Ultimately, this allowed us to offer our clients better products and services.").

${ }^{159}$ See infra Appendix, Chart 1 (charting the efficiency ratios of major U.S. banks).

${ }^{160}$ This is not the case, however, for even larger universal banks, where diseconomies of scope often appear to outweigh any gains in economies of scale. See supra text accompanying notes 158, 159; infra text accompanying note 162.

${ }^{161}$ See infra Appendix, Chart 1.

162 See Wheelock \& Wilson, supra note 155, at 665 (finding that "banks experience increasing returns to scale up to about $\$ 518$ million, constant returns at that point, and decreasing returns above \$518 million."); see also Guohua Feng \& Apostolos Serlitis, Efficiency, Technical Change, and Returns to Scale in Large U.S. Banks: Panel Data Evidence from an Output 
the $\$ 100$ billion to $\$ 500$ billion total average asset range appeared able to deploy larger distribution networks and technology platforms to outperform smaller banks. ${ }^{163}$

\section{iv. Evidence for Efficiencies of Scope}

Efficiencies of scope are the main goals of universal banks, though the difficulties of realizing this goal are well recognized. ${ }^{164}$ Indeed, the challenges had been crisply identified by one of the leading proponents of the universal banking model: Professor Canals, writing on the eve of the repeal of the Glass-Steagall Act, noted that

Distance Function Satisfying Theoretical Regularity, 34 J. BANKING \& FIN. 127, 127 (2010) (reviewing performance of "large" U.S. banks with assets over $\$ 1$ billion over the period from 2000 to 2005 and attributing improved performance to technology).

${ }_{163}$ Efficiency ratio data shows that smaller banks struggled to remain efficient in the face of their larger ( $\$ 100-\$ 500$ billion) competitors as the latter began to exploit their larger distribution networks and greater technology investment. See infra Appendix, Chart 1 (charting the efficiency ratios of large U.S. banks).

${ }^{164}$ For example, in 2006, the C.E.O. of Wachovia - one of the most successful exemplars of the universal bank model at that point - celebrated the emerging model, stating that

there is great value in the universal bank model for both customers and shareholders .... [I]t is not an easy model to execute, but if you can knit disparate businesses together in a way that brings great value to customers, you will undoubtedly also deliver exceptional value to shareholders .... Done right, size enhances competitive power .... [A] universal bank ... has much more to offer customers . . . With economies of scale, a company can better afford the technology and longer branch hours that customers demand.

Barbara A. Rehm, Wachovia Chief's Vision: Handful of Dominant Firms, AM. BANKER, May 19, 2006, at 2. At the time, other universal bankers, including Mr. Dimon, C.E.O. of JP Morgan, praised Mr. Thompson for his vision. See Matthias Rieker, Dimon on Deals and No-Deals, AM. BANKER, May 9, 2006, at 18 (describing Mr. Dimon's then-desire to expand JP Morgan's mortgage business); see also JPMORGAN CHASE \& Co., supra note 81 , at 30 (explaining the benefits of the universal bank strategy). 
[ $\mathrm{t}$ ] he chief problem is the tremendous complexity that universal banks must deal with when operating in businesses which, while sharing as common denominator the provision of financial services, differ considerably in their internal dynamics and distinctive features. Basically, the most important challenge a commercial bank must face . . . is that of increasing management complexity, a challenge that is heightened by the competition from banks specializing in certain businesses."

Our own study indicates no clear advantages for universal banks at this stage. ${ }^{166}$ A review of those studies that have attempted to discern efficiencies of scope is also generally discouraging. While some suggest that there is value to be gained from the risk diversification universal banks offer, ${ }^{167}$ these studies are either preCrisis, ${ }^{168}$ tentative or even dubious in their conclusions. ${ }^{169}$ Other studies suggest that there is a "diversification discount," rather than a diversification premium, imposed by the market on financial conglomerates. ${ }^{170}$ In addition, to the degree that conglomerates

${ }^{165}$ CANALS, supra note 59 , at 82.

166 See infra Appendix, Chart 1.

167 See, e.g., Lieven Baele et al., Does the Stock Market Value Bank Diversification?, 31 J. BANKING \& FIN. 1999, 2001 (2007).

${ }^{168}$ See, e.g., Rebecca S. Demsetz \& Philip E. Strahan. Diversification, Size, and Risk at Bank Holding Companies, 29 J. MONEY, CREDIT \& BANKING 300, 300 (1997) (a study conducted in the 1990s, long before the consequences of rapid consolidation became apparent in the Crisis and while banks were still relatively small).

${ }^{169}$ See e.g., Alan K. Reichert et al., The Final Frontier: The Integration of Banking and Commerce. Part 2: Risk and Return Using Efficient Portfolio Analysis, 93 FED. RESERVE BANK AtLANTA ECON. REV. 1, 12-13 (2008) (suggesting that portfolio diversification, or the combination of banking and commerce, could provide benefits but only when industry combinations are carefully made and corporate management is prepared to settle for "somewhat lower returns to achieve a substantial reduction in risk"); Kevin J. Stiroh \& Adrienne Rumble, The Dark Side of Diversification: The Case of US Financial Holding Companies, 30 J. BANKING \& FIN. 2131, 2158-60 (2006) (generally concluding that the risks associated with non-interestactivities "more than offset" the other benefits that might be gained from diversification).

${ }^{170}$ See e.g., Luc Laeven \& Ross Levine, Is There a Diversification Discount in Financial Conglomerates?, 85 J. FIN. ECON. 331, 331 (2007) ("We find 
concentrate the market, one study suggests that whatever gains the conglomerates themselves are able to extract are more than offset by the social costs of decreased competition and higher prices. ${ }^{171}$

Another study, which measured bank performance to 2006, suggests clear benefits from economies of "scale" but appears to have measured financial institutions that combined commercial and investment banking - in other words universal banks - and therefore does not anticipate diseconomies of scope. ${ }^{172}$ This was of course before these banks experienced massive losses suffered during and in the wake of the Crisis; thus, an obvious question is whether the supposed benefits were no more than temporary and whether latent diseconomies of scope were exposed by the Crisis.

It is therefore unlikely that clear and unambiguous evidence supporting economies of scope will emerge in the near future.

that there is a diversification discount: The market values of financial conglomerates that engage in multiple activities, e.g., lending and nonlending financial services, are lower than if those financial conglomerates were broken into financial intermediaries that specialize in the individual activities."); Larry H. P. Lang \& René M. Stulz, Tobin's q, Corporate Diversification, and Firm Performance, 102 J. POL. ECON. 1248, 1250 (1994) (finding a negative relationship between value and diversification).

${ }^{171}$ See generally Allen N. Berger \& Timothy H. Hannan, The Efficiency Cost of Market Power in the Banking Industry: A Test of the "Quiet Life" and Related Hypotheses, 80 REV. ECON. \& STAT. 454 (1998) (arguing that market concentration exacts social costs that reduce overall efficiency).

${ }^{172}$ Wheelock \& Wilson, supra note 155 , at 20. The authors also cite Feng \& Serilitis, supra note 162, in support of their conclusion. However, the latter study considered "large" banks with $\$ 1$ billion or more in total assets. $I d$. at 127. This baseline is far too low to be used in evaluating large banks today, which often hold $\$ 1$ trillion or more in total assets. As has been rightly observed, many of the supposed gains before the crisis of 2008 have turned out to be a mirage as the associated risks have materialized. Andrew Haldane et al., What is the Contribution of the Financial Sector: Miracle or Mirage?, in THE FUtURE OF FINANCE: THE LSE REPORT 64, 87 (Adair Turner et al. eds., 2010). 


\section{v. Clearing House Approach}

In the face of these perplexing challenges, The Clearing House has adopted a different approach to estimating the value of big banks. The Clearing House has approached the question of efficiency by making a relative assessment of the value of financial goods and services that may be offered when banks reach very large scale, as compared with the provision of similar services by smaller banks. For example, by measuring the cost of technology and distribution and processing infrastructure, The Clearing House is able to demonstrate how big banks can provide some financial services at a lower unit cost than smaller financial institutions. ${ }^{173}$

In the author's direct experience, these benefits are potentially real. ${ }^{174}$ Modern online financial services, for example, require enormous technology and operational investment that few small financial institutions can hope to afford, yet they also provide a new range of financial services, such as online account access, electronic payments and financial management that we already take for granted. Instant electronic payments clearance, debit and credit card services, wire transfers and the instant clearance and settlement of trades provide more examples. Altogether, The Clearing House estimates the cost of providing these services would be forty-five percent to fifty-five percent higher if no bank were larger than $\$ 50$ billion in total assets, which translates to an aggregate annual benefit from economies of scale of between $\$ 20$ billion and $\$ 45$ billion in the United States. ${ }^{175}$

\section{Capacity}

Big bankers have frequently insisted that their organizations need to be extremely large in order to provide the capacity necessary for supporting the needs of global clients. The CEO of JP Morgan, for example, explains that his organization must meet the demands of global clients by taking on necessary risk to support them,

${ }^{173}$ See TCH BANK ECONOMICS, supra note 52, at 9-15 (discussing banks' use of economies of scale).

${ }^{174}$ The author spent more than a decade on the business and technology side of one of the universal banks (Wachovia) and was directly involved in developing the platforms and electronic financial service lines made possible only by the very large scale of the company.

${ }^{175}$ TCH BANK ECONOMICS, supra note 52, at 15. 
underwriting billions of dollars of loans and securities and moving trillions of dollars of cash globally every day. ${ }^{176}$ Other industry leaders have made similar assertions, ${ }^{177}$ and there appears to be strong evidence that they are right.

The Clearing House has provided the most comprehensive analysis of the importance of large scale in providing the capacity for modern financial services. Scale enables banks to provide services that would either be cost-prohibitive, more expensive to end users or simply not available, if banks were confined to much smaller sizes. Many examples come from demands of global finance and capital markets. But many are also to be found in the arena of retail and consumer finance.

In the fields of corporate and investment banking, very big banks are important in many ways. One is for market-making and the provision of liquidity in large markets, ${ }^{178}$ particularly but not only in

${ }^{176}$ See JPMORGAN CHASE \& Co., supra note 81 , at 30 ("[I]n many ways, the size of our company is directly related to the size of the clients we serve globally. Our size supports the level of resources needed to service these large, multinational clients - and enables us to take on the necessary risk to support them . . . For some of our wholesale clients, we are asked to make bridge loans or underwrite securities of $\$ 10$ billion or more. We buy and sell trillions of dollars of securities a day and move some $\$ 10$ trillion of cash around the world every day. When we provide credit to a client, it may include revolving credit, trade finance, trading lines, intraday lines and derivatives lines - often in multiple locations globally - and often in the billions.").

177 Josef Ackermann, former chairman and C.E.O. of Deutsche (the third largest bank in the world by assets), recently wrote in defense of large banks:

It is . . important to recall that large banks are useful to the economy and business. They finance and hedge risk for companies that are active globally. They have the capacity to finance, arrange and handle the complexity of large deals. Moreover, large banks can better afford the increasingly expensive investments in information technology, risk management and market infrastructure that are also conducive to enhancing financial stability.

Josef Ackermann, Smaller Banks Will Not Make Us Safer, Fin. TimES, Jul. 30, 2009, at 9 (emphasis added).

${ }^{178}$ See, e.g., Patrick Jenkins \& Gillian Tett, Diamond Lashes Out at Obama Bank Plans, Fin. Times (Jan. 27, 2010, 11:21 AM), http://www.ft.com/ 
the field of public finance. ${ }^{179}$ It has even been argued that the importance of market making is actually the real reason why size is so critical for big banks. ${ }^{180}$

cms/s/f58ce0bc-0b30-11df-9109-00144feabdc0,dwp_uuid=abb716b0-2f7a11da-8b51-00000e2511c8 ("Mr. Diamond also pointed out that it was extremely hard to define proprietary trading - the practice of a bank betting its own capital on market movements - or to distinguish it from market making. 'The US has 8 trillion dollars of debt of which half, 4 trillion, is coming due in the next few months. There is a real need for banks such as Barclays to be actively trading that, to be placing with clients and providing liquidity."').

${ }_{179}$ On which fields, see infra text accompanying notes 193-207.

180 Yes, We Need Big Banks, ECON. OF CONTEMPT (Nov. 13, 2009, 1:32 AM), http://economicsofcontempt.blogspot.com/2009/11/yes-we-need-bigbanks.html (arguing that efforts to combat "too big to fail" are misguided because all major banks act as market makers and therefore require large balance sheets). In criticizing other pro-large bank supporters, the blogger observes that they "have somehow managed to avoid mentioning the one reason banks $d o$ actually need very large balance sheets: market-making." $I d$. He goes on to explain that banks

need a very large and diverse balance sheet to be a market-maker in fixed-income products-government securities, investment grade corporate bonds, high-yield bonds, mortgage-backed securities, bank and secured loans, consumer ABS, distressed debt, emerging market bonds, etc. Dealers hold inventories of all these securities because they need to remain 'ready and willing' to sell, and because when they buy a security from a client, they need to hold it in inventory until a buyer for the security appears. Dealers are exposed to price movements for the period they hold the security in inventory, and because inventories can grow large in a short amount of time, sharp price movements can result in substantial losses for dealers .... Another place there are economies of scale is order flow. The larger a dealer's order flow, the more trades it can match internally. This reduces volatility, allows a dealer to hold smaller inventories of securities, and reduces its exposure to sharp price movements. A lot of the financial industry's 'merger mania' over the past 15 years was driven by the race to capture order flow. So why do we need these massive market-makers in the first place? They ensure liquidity in the capital markets. And why is that important? For one thing, it lowers borrowing 
Yet, as demonstrated by The Clearing House, great scale provides benefits in many other arenas too: cash management and large loan syndication services to corporate customers; widespread and convenient availability of branch and ATM services to consumers; and inexpensive and rapid credit underwriting for borrowers such as credit card users. ${ }^{181}$ While it is conceivable that some or even all of these services could be delivered by consortia of much smaller financial institutions, it is likely that there would be sacrifices in terms of speed, convenience and cost to end users. The Clearing House estimates that the benefit of big banks in the provision of such services in the United States runs between $\$ 15$ billion to $\$ 35$ billion annually, with banks over $\$ 500$ billion being responsible for $\$ 10$ billion to $\$ 20$ billion of this total. ${ }^{182}$

Also important is the capability of financial innovation where large scale is a prerequisite to viability. "Financial innovation" is a term that has acquired unduly pejorative connotations because of the perceived roles played by exotic financial instruments during the Crisis. ${ }^{183}$ We take for granted the huge range of financial innovations

costs - investors are much more willing to buy a bond issue if they know they can quickly and easily sell the position later if they want to. Investors demand higher yields for illiquid bonds. The benefits of having massive market-makers were passed on to all the businesses that were able to borrow in the capital markets at a much lower cost, and to all the investors who enjoyed much higher returns due to the reduced transaction costs. Having liquid capital markets also allows the use of markto-market accounting, which is an important check on corporate management. During the whole nationalization debate, everyone was screaming bloody murder about the fact that the banks didn't have to mark their toxic assets to market. Well, if we 'break up' the major banks, as some simpletons pundits are urging, then you can forget about being able to mark-to-market lots of fixed-income products and OTC derivatives.

Id. (strikethrough in original).

181 See TCH BANK ECONOMICS, supra note 52, at 16-30 (providing illustrations from across the board in financial services and detailed case studies in commercial banking and capital markets).

${ }^{182}$ Id. at 16.

${ }^{183}$ Former Fed Chairman Paul Volcker famously (but wrongly) observed that the only worthwhile financial innovation of any value in the past twenty 
that have only been realistically affordable because they could be deployed across large platforms by banks large enough to afford the necessary investments. Electronic banking services, "on-us" settlement of bill payments and check imaging provide examples. ${ }^{184}$ Some of these innovations are only financially feasible when generated by a combination of products or services that could be combined, or more easily combined, by banks large enough to own both of the components. ${ }^{185}$ The Clearing House estimates that large banks have historically contributed approximately $\$ 15$ billion to $\$$ 30 billion in innovation value annually in advance of the point at which such innovation could be profitability adopted by smaller banks. ${ }^{186}$

\section{Global Competitiveness}

American bankers have long been concerned about their competitive position in global finance. Indeed, this anxiety was an important driver leading to the repeal of the Glass-Steagall Act. ${ }^{187}$ At the time, the asset sizes (though not necessarily the capital strength) of their foreign counterparts dwarfed U.S. big banks. In the years since the repeal of the Glass-Steagall Act, large foreign banks have occupied significant market share in U.S. domestic financial services.

The concern for American competitiveness is evident in $\mathrm{Mr}$. Geithner's "financial deepening" vision, described earlier. ${ }^{188} \mathrm{Mr}$. Dimon of JP Morgan has made perhaps the most explicit assertion on this point, citing evidence that American banks are losing market share. ${ }^{189}$

years had been the ATM. Eric Sorensen, Paul Volcker, Former Fed Chairman to Wall Street: “Wake Up, Gentlemen", HufFINGTON POST (Mar. 18, 2010, 6:12 AM), http://www.huffingtonpost.com/2009/12/09/paulvolcker-former-fed-c_n_385274.html.

${ }^{184}$ Of course, a multitude of small innovators and various bank consortia have developed such innovations. But, as any vendor with a new idea will attest, securing adoption by a large bank with a sufficiently broad customer base and the right combination of underlying products is critical if the innovation is to gain any traction.

${ }^{185}$ For a number of additional illustrations, see generally TCH BANK ECONOMICS, supra note 52, at 31-37.

${ }^{186} I d$. at 36.

${ }^{187}$ See supra text accompanying note 104.

${ }^{188}$ See supra text accompanying notes 48-50.

${ }^{189}$ JP Morgan's 2010 Annual Report stated: 
On the other hand, the demand for increasing bank size in order to meet global competition has been called a "fantasy" by one leading regulator. ${ }^{190}$ It certainly seems to have been contradicted by evidence that American banks were more profitable when they were much smaller than their European and Asian counterparts. ${ }^{191}$ At the same time, to the extent that real value is now generated by very

It's important that we make sure that American banks stay competitive[.]

We believe that it is good for America - the world's leading global economy - to have leading global banks. Being involved in the capital flows between corporations and investors across the globe is a critical function. Large, sophisticated institutions will be required to manage these flows and to intermediate or invest directly if necessary. Global markets will require sophisticated analysis, tools and execution.

The impact of ceding this role to banks based outside the United States could be detrimental to the U.S. economy and to U.S. companies. For a long time, the United States has had the deepest and best capital markets on the planet. These markets match investors with companies, large and small, who innovate, invest and grow around the world. They have helped build some of the best companies in the world and the best economy on the planet. America's financial institutions have been a critical part of this success.

JPMORGAN CHASE \& CO., supra note 81, at 31-32 (emphasis omitted). Mr. Dimon also acknowledges that "much of this change has to do with the growth of the rest of the world." Id. at 31.

190 Shahien Nasiripour, Top Fed Official Wants to Break Up Megabanks, Stop the Fed From Guaranteeing Wall Street's Profits, HuFFINGTON Post (June 2, 2010, 5:00 PM), http://www.huffingtonpost.com/2010/04/02/topfed-official-wants-to_n_521842.html (interview with Mr. Hoenig in which the then-President of the Kansas City Fed "[c]alled the idea that the U.S. needs megabanks to compete globally a 'fantasy"').

191 See Alan Gart \& Edward M. Pierce, Why Do Large U.S. Banks Outperform Their European Counterparts?, 19 STUD. ECON. \& FIN. 27, 27 (1998) (finding that, during the period between 1994 and 1996, bank profitability ratios in the United States and U.K. were "vastly superior" to those in Germany and Switzerland). 
large banks as a result of their scale capacity, ${ }^{192}$ they would clearly be disadvantaged competitively if, by being made much smaller, they would be up against the competition of very large foreign banks. Hence the "global competitiveness" argument would have some force, though to what extent is hard to estimate.

\section{4. "Instrumentalities of the State" $" 193$}

\section{i. Participants in Government Securities Markets}

Another important but often overlooked argument in favor of very big banks is that they serve as market makers, investors and secondary dealers in the essential process of massive government financing for federal, state and local government funding, as well as for foreign government debt finance. They have been critical participants in the government securities markets for more than a century. ${ }^{194}$ The list of primary dealers serving as trading

192 See supra text accompanying notes 176-186.

${ }^{193}$ In the United States, banks have always been recognized for the public role they play in finance. In this respect they have been treated as quasigovernmental agencies for the purposes of immunity from laws that would otherwise apply to regular corporations. See, e.g., M'Culloch v. Maryland, 17 U.S. 316, 354, 396, 422 (1819) (referring to the national bank as a "convenient, a useful, and essential instrument in the prosecution of fiscal operations" and remarking that "[t]he Bank of the United States is as much an instrument of the government for fiscal purposes, as the courts are its instruments for judicial purposes"); Osborn v. Bank of the U.S., 22 U.S. 738, 860 (1824) (describing the Bank of the United States as "the great instrument by which the fiscal operations of the government are effected"). Of course these decisions related to the Second Bank of the United States, but the same principle was also recognized with respect to the national banks chartered under the National Bank Act of 1863. See, e.g., Pollard v. State, 65 Ala. 628, 630 (1880) ("It now seems settled, by authority no longer capable of judicial disputation by the State courts, that the national banks are agents or instruments of the general government, designed to aid in the administration of an important branch of the public service . . .."); National Bank v. Kentucky, 76 U.S. 353, 361 (1869) (National banks are "the instrumentalities by which the government proposes to effect its lawful purposes in the States").

${ }^{194}$ In the United States, one of the most important reasons for the passage of the National Bank Act of 1863 and the creation of a national bank system was to ensure the availability of reliable federal currency as a means of 
counterparties of the Federal Reserve Bank of New York, for example, is largely a list of the ultra-large global banks. ${ }^{195}$

Government borrowing is so great now that it is hard to imagine it taking place without the participation of the very large banks capable of making and dealing in huge government securities markets. ${ }^{196}$ In 2010, large banks underwrote eighty-seven percent of the securities markets for U.S. federal, state and municipal governments, and the six largest U.S. banks - all with assets over $\$ 500$ million-were by far the biggest players. ${ }^{197}$ An indication of the volume involved is the fact that the total public debt outstanding stood at $\$ 15.5$ trillion as of March 31, 2012. ${ }^{198}$ The volume of domestic debt issuance has grown immensely in recent years ${ }^{199}$ and is strongly asserted to be a central reason for the importance of very

raising government finance in the wake of the Civil War. BRAY HAMMOND, SOVEREIGNTY AND AN EMPTY PURSE: BANKS AND POLITICS IN THE CIVIL WAR 285-317 (1970). For a description of the government debt system and the central role banks play in facilitating government finance, see Joseph Sherer, Commercial Banks and the Government Securities Market, 50 FED. RESERVE BANK N.Y MONTHLY REV. 215 (1968).

195 See Primary Dealers List, FED. RESERVE BANK OF N.Y., http://www.newyorkfed.org/markets/pridealers_current.html (last accessed Apr. 9, 2012) (listing "primary dealers", including Goldman, Deutsche and Citi).

${ }^{196}$ See TheCityUK, Financial Markets Series: Bond Markets 2 tbl. 2 (2011), available at http://www.thecityuk.com/assets/Uploads/ BondMarkets2011.pdf (showcasing in Table 2 a breakdown of the world's $\$ 38$ trillion public bond market by major country).

${ }^{197}$ TCH BANK ECONOMICS, supra note 52, at 29 (detailing the role large banks play in underwriting short- and long-term debt for state and local governments in the United States.)

${ }^{198}$ Bureau of the Pub. Debt, Monthly Statement of the Public Debt OF THE UNITED STATES MARCH 31, 2012, at 1 (2012), available at http://www.treasurydirect.gov/govt/reports/pd/mspd/2012/opds032012.pdf.

199 See Historical Debt Outstanding-Annual 2000 - 2010, TREASURYDIRECT, http://www.treasurydirect.gov/govt/reports/pd/histdebt/ histdebt_histo5.htm (last visited Apr. 18, 2012) (indicating the dramatic growth in public debt outstanding from 2000 (\$5.6 trillion) to the present); THECITYUK, supra note 196, at 1 chart 2 (showing the dramatic rise of government debt issuance as compared with that by financial institutions and corporate borrowers). For OECD area assessments, see Hans J. Blommestein et al., Highlights from the OECD Sovereign Borrowing Outlook 2012, 2011 OECD J.: FIN. MARKET TRENDS 253 (2012). 
big banks. ${ }^{200}$ Even the $\$ 37$ trillion municipal bond markets are heavily dependent on large bank participation. ${ }^{201}$

Indeed, the importance of "private" financial institutions to the government bond market may explain the exceptions for U.S. government securities that Congress has always made when imposing restrictions on investment activities, such as the GlassSteagall wall and, more recently, the Volcker Rule. ${ }^{202}$ The obvious incongruity of this exception at a time of government debt downgrades and sovereign debt crises is perhaps the basis for a recent political charge that the Volcker Rule is patently hypocritical. ${ }^{203}$

Ironically, objections to the Volcker Rule have also come from foreign governments whose debt, unlike that of the United States, is not exempt from the Rule's prohibitions on proprietary trading: They have complained vigorously that the restrictions imposed on their debt are "likely to increase borrowing costs for foreign governments, reduce liquidity and make the market for

\footnotetext{
${ }^{200}$ See, e.g., Jenkins \& Tett, supra note 178.

${ }^{201}$ See, e.g, Letter from Howard Marsh, Managing Dir. \& Head of the Mun. Sec. Div., Citigroup Global Mkts., to the Office of the Comptroller of the Currency, Bd. of Governors of the Fed. Reserve Sys., Fed. Deposit Ins. Corp. \& Sec. \& Exch. Comm'n 5 (Jan. 27, 2012), available at http://www.federalreserve.gov/SECRS/2012/January/20120131/R-1432/R1432_013012_88700_399129030066_1.pdf (arguing that the Volcker Proposal's exemption of government obligations from proprietary trading restrictions should not exclude the "obligations of an agency of any State or political subdivision thereof").

${ }^{202}$ Dodd-Frank Act, Pub. L. No. 111-203, § 619, 124 Stat.1376, 1620-31 (2010) (to be codified at 12 U.S.C. $\S 1851$ ).

${ }^{203}$ See Kevin Wack, GOP Lawmaker Sees Double Standard in Volcker Rule: Corker Slams Volcker Carve-Outs, AM. BANKeR (Jan. 24, 2012, 2:06 PM), http://www.americanbanker.com/issues/177_16/bob-corker-volckerrule-dodd-frank-1046002-1.html (reporting on a speech by Sen. Bob Corker, a senior member of the Senate Banking Committee, charging that the exemption was "nothing but a political move .... obviously the Fed and Treasury wanted to make sure that they exempted the things they cared most about.").
} 
foreign government bonds more volatile,"204 and that the Rule "could have a significant adverse impact on sovereign debt markets." "205

In other words, governments, including the United States and lower level governments, cannot do without very big banks. Sometimes, in a classic case of reversal of fortune, they themselves seek bailouts from the banks. ${ }^{206}$ What has evolved is a grand codependency between sovereigns and banks, one that is most starkly acknowledged in the response by a leading banker of our time when asked if it was not unhealthy to keep encouraging banks to load up on ailing sovereign debt: "If Italy goes down, and you're an Italian bank, you're going down too."207

\section{ii. Bailout Agents for Government}

During the Financial Crisis, the government marshaled the aid of the largest banks in the country to help deal with the failure of other large financial institutions. JP Morgan took over Bear Stearns and Washington Mutual; Bank of America absorbed Countrywide and Merrill Lynch; and Wells Fargo absorbed Wachovia (after the Federal Deposit Insurance Corporation ("FDIC") had already attempted, to the suspicion of some, to use Wachovia to prop up

${ }^{204}$ Andrew Ross Sorkin, Volcker Rule Stirs Up Opposition Overseas, N.Y. TIMES DEALB\%K (Jan. 30, 2012, 8:59 PM) http://dealbook. nytimes.com/2012/01/30/volcker-rule-stirs-up-opposition-overseas.

205 See id. (quoting the British Chancellor of the Exchequer, George Osborne).

${ }^{206}$ See David Enrich et al., European Nations Pressure Own Banks for Loans, Wall St. J., Nov. 29, 2011, at A1 (describing the dependence by European governments on bank loans during the Euro Crisis); Dara Doyle \& Joe Brennan, Captive Irish Banks May Help Avoid Bailout Two in Bond Swap, BloOMBERG (Feb. 1, 2012, 3:59 AM), http://www.businessweek. com/news/2012-01-31/captive-irish-banks-may-help-avoid-bailout-two-inbond-swap.html (reporting on the substitution, of government debt, by formerly bailed-out Irish banks to a less expensive note).

${ }^{207}$ Joe Wiesenthal, Jamie Dimon NAILS It On Europe and the ECB, BUS. INSIDER CLUSTERSTOCK (Jan. 26, 2012, 6:18 AM), http://www. businessinsider.com/jamie-dimon-nails-it-on-europe-and-the-ecb-2012-1

(paraphrasing remarks made in a CNBC interview by the JP Morgan CEO and astutely adding his own observation: "Nailed it. Ultimately there's no divorcing the fate of a sovereign and the fates of banks within the country. Might as well get them to finance each other."). 
Citigroup $^{208}$ ). It is unlikely that the federal government would have had the resources available to manage the direct liquidations of these institutions. ${ }^{209}$ When partners for other ailing investment banks could not be found, the government arranged alternative government privileges and facilities for those struggling institutions. ${ }^{210}$

Using a "healthier" bank to absorb a failing bank is one technique on which the FDIC has long relied. ${ }^{211}$ In the 2008 process,

${ }^{208}$ See ROTHACKER, supra note 120 , at 134 (describing the suspicion that FDIC Chairman, Sheila Bair, favored an acquisition of Wachovia by Citi over one by Wells because Citi was itself in need of help); Joe Nocera, Sheila Bair's Bank Shot, N.Y. TIMES, July 10, 2011, at MM24 (describing Chairman Bair's desire to use Wachovia to save Citi). Whether this was Bair's real intention is unknown.

209 On December 31, 2007, the Federal Deposit Insurance Fund had a balance of $\$ 51,277,000,000$. Chief Financial Officer's (CFO) Report to the Board: DIF Balance Sheet-Second Quarter 2007, FDIC: FED. DEPOSIT INS. CORP. (Sept. 13, 2007), http://www.fdic.gov/about/strategic/ corporate/cfo_report_2ndqtr_07/balance.html. This represented a reserve ratio of $1.22 \%$ of its exposure to insured deposits, totaling about $\$ 4.29$ trillion. See Memorandum from Arthur J. Murton, Dir., Div. of Ins. \& Research, Fed. Deposit Ins. Corp. 1 (Mar. 10, 2008), available at http://www.fdic.gov/deposit/insurance/assessments/assessment_rates_2008. pdf. The Fund does have the ability to borrow up to $\$ 500$ billion from the Treasury. Helping Families Save Their Homes Act of 2009, Pub. L. No. 111-22, § 204(c)(1)(D), 123 Stat. 1632, 1649 (to be codified at 12 U.S.C. $\S$ 1824(a)(3)(A)).

${ }^{210}$ Goldman and Morgan Stanley became bank holding companies during the financial crisis, which gave them access to the Fed's discount window and allowed them to borrow repeatedly. As Goldman and Morgan Shift, a Wall St. Era Ends, N.Y. Times DeALB\%K, (Sept. 21, 2008, 9:35 PM), http://dealbook.nytimes.com/2008/09/21/goldman-morgan-to-become-bankholding-companies; see also Goldman Went to Fed Discount Window Five Times, ReuTERS (Mar. 31, 2011, 8:19 PM), available at http://www. reuters.com/article/2011/04/01/us-usa-fed-goldmansachs-

idUSTRE73002X20110401 (stating that Goldman borrowed money from the Fed five times); Michael J. Moore \& Dakin Campbell, Morgan Stanley Got \$6.9 Billion From Fed Window in October 2008, BLOOMBERG (Mar. 31, 2011, 4:58 PM), http://www.businessweek.com/news/2011-0331/morgan-stanley-got-6-9-billion-from-fed-window-in-october-2008.html (stating that Morgan Stanley borrowed $\$ 6.9$ billion from the Fed in October 2008).

${ }^{211}$ This is referred to as a "purchase and assumption (P\&A) transaction," in which a healthy institution purchases some or all of the assets of a failed bank and assumes some or all of its liabilities, including insured deposits. 
however, the mergers involved were hardly the kind of thoughtful combinations investors would be entitled to expect during calmer times, ${ }^{212}$ and the result only made already large and weakly capitalized banks even bigger and more heavily burdened. All of the resulting entities needed subsequent bailouts through various means, the most prominent of which was the Troubled Asset Relief Program ("TARP") but which also included secret emergency lending by the Federal Reserve ("Fed"). ${ }^{213}$ The need for subsequent government assistance indicates that perhaps the banking agencies headed in precisely the wrong direction by creating even larger, weaker banks as a means of extricating the financial system from its crisis.

Yet it has become patently clear that, as a matter of policy, the U.S. government continues to depend on big banks as agents for bailing out failing institutions. When it imposed a total consolidated

The FDIC often provides guarantees against losses. A P\&A transaction is attractive to the FDIC because it can greatly reduce the initial cash outlay that would otherwise have to be made to render insured depositors whole. See Fed. Deposit Ins. CorP., Resolutions Handbook 19-23 (2003), available at $\mathrm{http} / / / \mathrm{www} . f d i c . g o v / \mathrm{bank} / \mathrm{historical} / \mathrm{reshandbook} / \mathrm{ch} 3$ pas.pdf.

${ }^{212}$ See supra text accompanying note 114.

${ }^{213}$ For a description of these programs and how they effectively subsidized the recovery of nearly all the big banks, see, e.g., Gretchen Morgenson, The Bank Run We Knew So Little About, N.Y. TIMES, Apr. 3, 2011, at BU1; Bob Ivry et al., Secret Fed Loans Gave Banks \$13 Billion Undisclosed to Congress, BlOOMBERG (Nov. 27, 2011, 7:01 PM), http://www.bloomberg. com/news/2011-11-28/secret-fed-loans-undisclosed-to-congress-gavebanks-13-billion-in-income.html; Bob Ivry, Fed Gave Banks Crisis Gains on $\$ 80$ Billion Secretive Loans as Low as 0.01\%, BLOOMBERG (May 26, 2011, 10:47 AM), http://www.bloomberg.com/news/2011-05-26/fed-gavebanks-crisis-gains-on-secretive-loans-as-low-as-0-01-.html; Craig Torres \& Bob Ivry, Dying Banks Kept Alive Show Secrets Fed's Data Will Reveal for First Time, BLOOMBERG (Mar. 29, 2011, 1:48 PM), http://www.bloomberg. com/news/2011-03-29/dying-banks-kept-alive-show-secrets-fed-s-data-willreveal-for-first-time.html. The Fed has refuted some of these assessments. See generally Letter from Ben S. Bernanke, Chairman, Fed. Reserve, to Tim Johnson, Chairman, Sen. Comm. on Banking, Hous. \& Urban Dev., and Richard Shelby, Ranking Member, Sen. Comm. on Banking, Hous. \& Urban Dev. (Dec. 6, 2011), available at http://www.federalreserve.gov/ generalinfo/foia/emergency-lending-financial-crisis-20111206.pdf. For a response, see generally Bloomberg News Responds to Bernanke Criticism of U.S. Bank-Rescue Coverage, BloOMBERG (Dec. 7, 2011, 5:31 PM), http:// www.bloomberg.com/news/2011-12-06/bloomberg-news-responds-tobernanke-criticism.html. 
liabilities cap of ten percent on future mergers between financial institutions, Congress specifically exempted from this restriction the acquisition of banks in default or in danger of default. ${ }^{214}$ The utility of big banks as a device for resolving large financial institution failures was thereby endorsed as an express policy for promoting financial stability.

This reliance on big banks became even clearer during the implementation of the Dodd-Frank Act. The newly-created Financial Stability Oversight Council ("FSOC") was required by Section 622 of the Dodd-Frank Act to undertake a study and make recommendations regarding the concentration limits on LCFIs, and whether these should be modified. ${ }^{215}$ Specifically, the FSOC was charged with considering "the extent to which the concentration limit would affect financial stability, moral hazard in the financial system, the efficiency and competitiveness of United States financial firms and financial markets, and the cost and availability of credit and other financial services to households and businesses in the United States.",216

This was a golden opportunity for the FSOC to address the question of whether LCFIs had already become too large, an especially important inquiry if their further growth were to occur through mergers. The FSOC released its report in January 2011. ${ }^{217}$ Although the FSOC concluded that the Dodd-Frank Act's cap of ten percent on total consolidated liabilities was superior to the RiegleNeal cap of ten percent on total deposits, and that the cap would have the long-run effect of enhancing "the competitiveness of U.S. financial markets by preventing the increased dominance of those markets by a very small number of firms, ${ }^{218}$ the FSOC went on to

${ }^{214}$ Dodd-Frank Act, Pub. L. No. 111-203, § 622, 124 Stat.1376, 1633 (2010) (to be codified at 12 U.S.C. § 1852(c)(3)); see generally 12 U.S.C. $\S$ 1842(d)(2)(A) (2006) (imposing a ten percent limitation).

${ }^{215}$ Dodd-Frank Act $\S 622$ (to be codified at 12 U.S.C. $\$ 1852(\mathrm{e})(1)$ ).

${ }^{216} \mathrm{Id}$.

217 See generally Fin. STABILITy Oversight Council, Study \& RECOMMENDATIONS REGARDING CONCENTRATION LIMITS ON LARGE FINANCIAL COMPANIES (Jan. 2011) [hereinafter FSOC CONCENTRATION REPORT], available at http://www.treasury.gov/initiatives/ Documents/Study\%20on\%20Concentration\%20Limits\%20on\%20Large $\% 2$ 0Firms\%2001-17-11.pdf.

${ }^{218} I d$. at $4,8-13$. 
recommend that the failing bank exception be extended beyond "banks" to all types of depository institutions. ${ }^{219}$

Thus, another important rationale for the biggest banks is that they serve a public, quasi-governmental purpose in assisting the government to maintain stability in financial crises in a way that reduces, in the short term at least, the cost to the public. ${ }^{220}$

\section{Public Costs of Big Banks}

The Clearing House estimates that the "the 26 largest U.S. banks provide an estimated $\$ 50$ billion to $\$ 110$ billion worth of marginal value annually to the economy, as compared to banks with $\$ 50$ billion in assets or alternative non-bank solutions." ${ }^{, 21}$ This is the estimate of value directly enjoyed by end users, the bank customers. The Clearing House also argues that the potential benefits to customers in competitive markets of lower prices and the possible benefits to shareholders in the form of greater returns should be taken into account. ${ }^{222}$ And while these dimensions of benefit might be measurable, anecdotal evidence of customer dissatisfaction with fees $^{223}$ and the poor performance of many big bank shares ${ }^{224}$ might

${ }^{219}$ See id. at 16, 21-22 ("The Council believes that the important policy that supports the exception for the acquisition of failing banks-namely, the strong public interest in limiting the costs to the Deposit Insurance Fund that could arise if a bank were to fail, which might be partly or wholly limited through acquisition of a failing bank by another firm-applies equally to insured depository institutions generally, and is not limited to "banks" as that terms in defined in the BHC Act.").

${ }^{220}$ Whether this policy is well advised, and whether the government has any choice given the size of big banks and the limits on public resources, is an entirely different matter.

${ }^{221}$ TCH BANK ECONOMICS, supra note 52, at 37.

${ }^{222} \mathrm{Id}$.

${ }^{223}$ Big banks seldom match the customer satisfaction levels of their smaller counterparts and they significantly trail the average results for all industries. See, e.g., The American Customer Satisfaction Index-Scores by Industry, AM. CUSTOMER SATISFACTION INDEX, http:/www.theacsi.org/ index.php?option $=$ com_content $\&$ view $=$ article $\& i d=147 \&$ catid $=\&$ Itemid $=21$ 2\&i=Banks (last visited Mar. 15, 2012); see also, e.g., Press Release, American Customer Satisfaction Index, ACSI: Declining Customer Satisfaction with Healthcare Insurance Dampens Small Improvements for Banks and Life Insurance (Dec. 14, 2010), available at http://www. theacsi.org/images/stories/images/news/10dec_press.pdf (describing modest improvements in customer satisfaction among banks, but noting that small 
suggest that there has been a net reduction in value rather than an increase.

More importantly, one should also weigh against the actual and potential benefits the external costs. There are many, and they take various forms. Some benefits and costs are difficult to assess, if they exist at all, and would likely require extensive empirical study. For example, it is often argued by big bank advocates that their institutions can reduce risk, particularly if they are structured as diversified universal banks. ${ }^{225}$ On the other hand, the question whether large banks also generate additional social costs through negligence and even criminality due to the difficulty of controlling the actions of their employees also awaits empirical research and could be a significant public cost. ${ }^{226}$

banks performed better than large banks); Richard H. Thaler, When Businesses Can't Foresee Outrage, N.Y. TIMES, Nov. 20, 2011, at BU4 (describing customer dissatisfaction with banks' decisions to charge fees that are not "transparent and salient").

${ }^{224}$ See S\&P Banking Index,-Five Year View, YAhoo! FinanCE, $\mathrm{http} / / /$ finance.yahoo.com (last visited Mar. 15, 2012) (into the query bar next to the "Get Quotes" button, type "^BIX"; then follow the "Basic Chart" hyperlink; then adjust the range of the chart to show a five-year range by following the "5y" hyperlink above the chart) (depicting the dramatic fall in bank share values following the crisis andillustrating the difficulty those shares have collectively had reaching pre-crisis levels).

${ }^{225}$ See, e.g., Ackermann, supra note 177 (arguing that greater market integration through big banking will assist in risk diversification); see also Thorsten Beck et al., Bank Concentration, Competition, and Crises: First Results, 30 J. BANKING \& FIN. 1581, 1581 (2006) ("[W]e find that crises are less likely in economies with more concentrated banking systems . ..."). But see Haldane et al., supra note 172, at 66-76 (measuring the direct and indirect contributions to output made by the financial sector and adjusting this value for risk, to demonstrate that, despite increases in nominal ROE, risk-adjusted ROEs did not increase).

${ }^{226}$ Some commentators take the view that some big banks have essentially become systematic criminal conspiracies. See, e.g., William K. Black, 'Control Frauds' as Financial Super-Predators: How 'Pathogens' Make Financial Markets Efficient, 34 J. Socio-ECONOMICS 734 (2005); William K. Black, Assoc. Professor, Univ. of Mo.-Kansas City, Testimony Before the Financial Crisis Inquiry Commission (Sept. 21, 2010) (transcript available at http://fcic-static.law.stanford.edu/cdn_media/fcic-testimony/ 2010-0921-William-Black.pdf); Matt Taibbi, Why Isn't Wall Street in Jail?, Rolling STONE (Feb. 16, 2011, 9:00 AM), http://www.rollingstone.com/ politics/news/why-isnt-wall-street-in-jail-20110216. One need not draw this 
Some costs, however, are more tangible.

\section{A. Direct and Indirect Public Subsidies}

In the aftermath of the recent financial crisis, it seems anomalous that we would simply accept a situation in which a heavily subsidized industry is able to produce great profits, a very large proportion of which are then paid out as unprecedented levels of executive compensation, ${ }^{227}$ while that industry continues to enjoy government - U.S. taxpayer - support.

The public subsidies provided to big banks are substantial, and the financial markets factor these into their valuations. In one of many graphic illustrations, Standard \& Poor's ("S\&P") downgraded Citibank Korea ("CK") to standalone status because S\&P believed there was "uncertainty" about whether the United States government wanted CK's parent, Citigroup, to provide its subsidiary additional financial support. Citigroup itself enjoyed an A- rating (instead of BBB-), precisely because of its own receipt of government assistance. $^{228}$ Estimating the anticipated degree of government

conclusion to recognize the substantial criminal and quasi-criminal output reflected in enforcement sanctions, guilty pleas and the like that are now common penalties exacted on big banks through the courts and regulatory agencies. Repeat enforcement actions for serious breaches of banking and securities laws, including fraud, have led to numerous agency enforcement actions but have been criticized for their apparent lack of deterrence. See, e.g., Edward Wyatt, Promises Made, and Remade, by Firms in S.E.C. Fraud Cases, N.Y. TiMES, Nov. 8, 2011, at A1.

${ }^{227}$ It has been estimated that "substantial 'rents' above and beyond what would have been required to call forth the services of equally intelligent, well-trained individuals" are included in the compensation paid to financial industry employees, and that bonuses in the financial industry constitute a very substantial proportion of the total profits earned by the industry. F. M. Scherer, A Perplexed Economist Confronts 'Too Big to Fail', 7 EuR. J. COMP. ECON. 267, 270-71 (2010); cf. Thomas Philippon \& Ariell Reshef, Wages and Human Capital in the U.S. Financial Industry: 1909-2006, at 2 (Nat'l Bureau Econ. Research, Working Paper 14644, 2009), available at http:/www.nber.org/papers/w14644.pdf (estimating that rents-i.e. compensation over and above what might otherwise be generated by normal competition - in financial sector compensation from the mid-1990s to 2006 ran between thirty percent and fifty percent when compared with the rest of the private sector).

228 Peter Eavis, Banks' Safety Net Fraying, WALL ST. J., November 16, 2009, at C6. 
support to a failing financial institution is now routine for rating agencies, ${ }^{229}$ which in turn directly affects the cost of debt and is commonly referred to by investment analysts as an important factor in estimating shareholder value. ${ }^{230}$

Public subsidies derive from multiple sources. ${ }^{231}$ Some stem from collective systemic assurance in the form of a federal reserve system, including access to the discount window and a host of favorable, below-market-cost emergency lending facilities, ${ }^{232}$ and federal deposit insurance. ${ }^{233}$ Others subsidies are both direct and

${ }^{229}$ See, e.g., Moody's Downgrades Bank of America Corp. to Baal/P-2; Bank of America N.A. to A2, P-1 Affirmed, MoOdy's InVESTORS SERVICE (Sept. 21, 2011), http://www.moodys.com/research/Moodys-downgradesBank-of-America-Corp-to-Baa1P-2-Bank--PR_226511.

${ }^{230}$ See, e.g., Mark Gongloff, Big Banks Would Have BBB Ratings Without Government Props, Wall St. J. MARKETBEAT (June 2, 2011, 10:31 AM), http://blogs.wsj.com/marketbeat/2011/06/02/banks-how-theyd-be-rated-

without-government-support; STANDARD \& POOR'S, THE U.S. GOVERNMENT SAYS SUPPORT For BANKS WILl BE DifFERENT "NeXT TIME"-BUT WiLL IT? (2010).

${ }^{231}$ Support comes not only from the implicit guarantee that the institution will not be allowed to fail, but also from other sources such as membership in the Fed (and therefore privileged access to liquidity), federal deposit insurance and special accounting treatment. See Kenneth Jones \& Barry Kolatch, The Federal Safety Net, Banking Subsidies, and Implications for Financial Modernization, 12 FDIC BANKING REV. 1, 1 (1999) (defining the "federal safety net" as access to the Fed discount window and FDIC insurance).

${ }^{232}$ See, e.g., Ivry, supra note 213.

233 See The Federal Deposit Insurance System: Hearing Before the S. Comm. on Banking, Hous., \& Urban Affairs, 108th Cong. 41-46 (2003) (statement of Alan Greenspan, Chairman, Bd. of Governors of the Fed. Reserve Sys.) (describing the anomaly of what had by that time become free deposit insurance for well-capitalized and highly rated institutions, creating moral hazard problems and distortions in resource allocation). The scale of deposit insurance has reached absurd levels under the Transaction Guarantee Program created during the Crisis. In many situations depositors, both retail and commercial, can expect $100 \%$ in the event of failure, and it is by no means certain that the cost of this insurance is accurately priced. Not only is it a source of moral hazard, but it is also a great implicit subsidy. For a recent discussion, see Barbara A. Rehm, Rehm on TAG: Don't Extend It, End It, AM. BANKER (Feb. 23, 2012, 1:07 PM), http://www. americanbanker.com/issues/177_36/rehm-transaction-account-guaranteeprogram-1046869-1.html. 
indirect, including special accounting treatment ${ }^{234}$ and specific tax breaks to banks undertaking rescue mergers ${ }^{235}$ or reaching enforcement settlements. ${ }^{236}$

The extent of just one portion of this overall network of subsidies to big banks - the support provided through the TARP program $^{237}$ - has been estimated at about $\$ 34$ billion per year. ${ }^{238}$ The

${ }^{234}$ See Chris BRummer, Soft LAW AND the Global FinANCial System: RULE MAKING IN THE 21ST CENTURY 146 (2012) (describing the U.S. accounting system of classifying financial assets as "available for sale," allowing some financial managers to report changes in fair value as adjustments to shareholder equity and thus "bypass the income statement altogether"); Edward Iwata, Will Going Global Extend to Accounting? Switching to International Rules Has Its Pros and Cons, USA TODAY, Jan. 6,2009 , at 1B (describing U.S. companies' resistance to moving to global accounting standards, which have stricter balance-sheet practices).

${ }^{235}$ See, e.g., Dan Fitzpatrick, FDIC Stands Between J.P. Morgan and a Tax Windfall, WALL ST. J., Mar. 29, 2010, at C1 (discussing FDIC objections to a \$1.4 billion tax advantage JP Morgan would receive as a result of acquiring Washington Mutual as part of a government-triaged rescue).

${ }^{236}$ See, e.g., Ben Walsh, Dear Taxpayers: You Might Be on the Hook for Way More of the $\$ 40$ Billion Mortgage Settlement than You Thought, Bus. INSIDER CLUSTERSTOCK (Feb. 17, 2012, 3:07 PM), http://www. businessinsider.com/dear-taxpayers-you-might-be-on-the-hook-for-waymore-of-the-40-billion-mortgage-settlement-than-you-thought-2012-2 (noting reports that suggest that taxpayers will effectively pay for over eighty percent of the $\$ 40$ billion mortgage settlement reached between five big banks, the United States and state attorneys general). The Obama Administration has refuted this assessment. See U.S. Dept. of Housing \& Urban Dev., HAMP's Role in the Settlement, The HUDdle (Feb. 22, 2012), http://blog.hud.gov/2012/02/22/hamp's-role-in-the-settlement. For the official web site of the mortgage settlement, see NAT'L MORTGAGE SETTLEMENT, http://www.nationalmortgagesettlement.com/ (last visited Apr. 9, 2012).

${ }^{237}$ See generally Emergency Economic Stabilization Act of 2008, Pub. L. No. $110-343, \S 101$ (a), 122 Stat. 3765,3767 (to be codified at 12 U.S.C. $\S$ 5211(a)(1)) (authorizing the establishment of the Troubled Asset Relief Program (TARP)).

238 See Dean Baker \& Travis Mcarthur, Ctr. for Econ. \& Policy Research, The Value of the "Too Big to Fail" Big BanK Subsidy 2 (2009), available at $\mathrm{http}: / / \mathrm{www} . c e p r . n e t / d o c u m e n t s /$ publications/too-big-tofail-2009-09.pdf. The estimate is based on the relative cost of funds for toobig-to-fail banks, using FDIC data, before and after the financial crisis and the extension of government assistance in the wake of the crisis. For an earlier assessment, see Edward J. Kane, Incentives for Banking 
Bank of England and its leading financial regulator, Andrew Haldane, have estimated that the implied public subsidy of public support to the largest twenty-eight TBTF banks, including many from the United States, ran as high as $\$ 250$ billion in $2009 .{ }^{239}$ Using another, ex ante methodology (bank stock returns), other researchers have more recently come up with a more general annual TBTF subsidy value of $\$ 4.71$ billion per TBTF bank in 2005 dollars. ${ }^{240}$ Research even suggests that financial institutions have paid a collective $\$ 14$ billion in additional merger premiums to acquire the status of TBTF and enjoy the public subsidy that this status accords. ${ }^{241}$

Such subsidies also do not include retroactive tax allowances received for the losses suffered during the Financial Crisis. Stimulus legislation enacted in $2009^{242}$ is reported to permit companies to deduct from taxes paid in earlier years the losses that they suffered between 2008 and 2009. This benefit is particularly valuable to financial institutions, such as JP Morgan, that took over failing firms, such as Washington Mutual. ${ }^{243}$

Of course direct and indirect public subsidies to big banks measure only one aspect of their external costs. Another

Megamergers: What Motives Might Regulators Infer from Event-Study Evidence?, 32 J. MONEY, CREDIT \& BANKING 671, 673 (2000).

${ }^{239}$ See Haldane, supra note 42 , at 105 tbl.4. Haldane estimates that this form of subsidy ran as high as $£ 107$ billion in 2009 for U.K. banks alone.

${ }^{240}$ Priyank Gandhi \& Hanno Lustig, Size Anomalies in U.S. Bank Stock Returns 5 (Nat'l Bureau of Econ. Research, Working Paper No. 16553, 2010), available at $\mathrm{http}: / / \mathrm{ssrn} . \mathrm{com} / \mathrm{abstract}=1653083$.

${ }^{241}$ Elijah Brewer III \& Julapa Jagtiani, How Much Did Banks Pay to Become Too-Big-To Fail and to Become Systemically Important?, 41 J. FIN. SERVICES RES. (forthcoming 2012); see also Philip Molyneux et al., "TooBig-To-Fail" and Its Impact on Safety Net Subsidies and Systemic Risk 13 (Ctr. for Applied Research in Fin., Working Paper No. 09/2010, 2010), available at $\mathrm{http} / / / \mathrm{ssrn} . \mathrm{com} / \mathrm{abstract}=1798633$ (reviewing mergers in Europe and coming to the tentative conclusion that part of the objective of these mergers is to secure "too-systemically-important-to-fail" status and the government protection that this accords).

${ }_{242}$ See generally American Recovery and Reinvestment Act of 2009, Pub. L. No. 111-5, 123 Stat. 115.

${ }^{243}$ See Scott Thurm \& Dan Fitzpatrick, Tax-Break Battle Flares, WALl ST. J., Mar. 24, 2009, at A1 (reporting that, in the case of JP Morgan, the value of this tax break could be as high as $\$ 1.4$ billion because the company may be permitted to deduct losses incurred by Washington Mutual, which JP Morgan took over, against taxes paid the previous five years). 
externalization, which is more amorphous yet far greater, is the more general costs to domestic and global economies of financial crises when they arise. Such costs, sometimes discounted in economic analysis as "exogenous events," represent externalities borne by taxpayers and the general public and not directly by the shareholders of the contributing banks. They are represented by years of stunted growth and economic recovery, major government stimulus programs, government expenditure cuts and unemployment. Economists have measured these costs. ${ }^{244}$ They cannot of course be fairly allocated to big banks alone because crises, in which big banks can become enmeshed through no fault of their own, can have multiple causes, including government mismanagement, unforeseen catastrophes such as wars and so on. ${ }^{245}$ The magnifying effect of big bank collapses during crises should nevertheless be borne in mind when considering the social and economic costs of such large scale banking operations.

\section{B. Market Power and Repression of Competition}

The banking industry has concentrated substantially in the past twenty years. There are few studies that attempt to measure the anti-competitive effects of universal banking. Congress was clearly aware of the possibilities when, in 1994, it imposed a ten percent nationwide deposit share cap on banks wishing to make new out-ofstate acquisitions, and again when it added a ten percent consolidated liabilities cap for new mergers in 2010 with the Dodd-Frank Act. ${ }^{246}$

\footnotetext{
${ }^{244}$ See, e.g. REINHART \& ROGOFF, supra note 20, at 162-71 (focusing on the long-term impact on government revenues and debt, which the authors argue is a more complete assessment than a study of "bailout costs"); Falko Fecht et al., Financial Globalization and Stability, in GlOBALIZATION AND SYSTEMIC Risk 53, 72 (Douglas D. Evanoff et al. eds., 2009) (reviewing measures of the social costs of crises).

${ }_{245}^{245}$ See supra note 28.

${ }^{246}$ See supra text accompanying notes $217-219$. The Financial Stability Oversight Council ("FSOC"), acting pursuant to a mandate under Section 622 of the Dodd-Frank Act, has made some attempt to determine the impact of concentration on competition (among other dimensions such as financial stability, moral hazard, and cost and availability of credit). Its analysis is focused on whether the concentration limit already created by the DoddFrank Act will promote competition, not whether the current size and continued growth (without acquisition) of big banks has a negative impact on competition. FSOC CONCENTRATION REPORT, supra note 217, at 411.
} 
Large bank CEOs sometimes protest that the U.S. banking market is much less concentrated than other markets and that far more concentrated markets did not experience difficulties. ${ }^{247}$ It is naïve, however, to cite the thousands of U.S. banks as representing a low concentration market; in fact the market in large finance has become highly concentrated in the United States in recent years. ${ }^{248}$ Anecdotal reports also suggest that big banks have used market power to gain business at the expense of smaller institutions. ${ }^{249}$ Some

${ }^{247}$ JP Morgan's 2010 Annual Report states:

Consolidation does not cause crises, and the U.S. banking system is far less consolidated than most other countries. The U.S. banking system has gone from approximately 20,000 banks 30 years ago to approximately 7,000 today. That trend likely will continue as banks seek out economies of scale and competitive advantage. That does not mean there won't be start-ups and successful community banks. It just means that, in general, consolidation will continue, as it has in many industries.

The U.S. system is still far less consolidated than most other countries ....

In any case, the degree of industry consolidation has not, in and of itself, been a driving force behind the financial crisis. In fact, some countries that were far more consolidated (Canada, Australia, Brazil, China and Japan, to name a few) had no problems during this crisis so there is not compelling evidence to back up the notion that consolidation was a major cause of the problem.

JPMORGAN CHASE \& CO., supra note 81 , at 30.

${ }^{248}$ See Simon Johnson \& JAMES KwaK, 13 BAnkers: The Wall Street TAKEOVER AND THE NEXT FINANCIAL MELTDOWN 180 (2010) (observing that, in the wake of the financial crisis, "[c]onsolidation among the big banks and the collapse of the nonbank mortgage lenders meant much larger market shares for the fewer but bigger megabanks"); supra text accompanying notes 58-78 and 197-201.

${ }^{249}$ See, e.g., Dan Fitzpatrick \& Robin Sidel, A City Feels the Squeeze in the Age of Mega-Banks, Wall ST. J., Jul. 20, 2010, at A1 (describing the market impacts, including anti-competitive pressure, of bank consolidation in the wake of the financial crisis); David Reilly, Banking Whales Outpace Minnows, WALL ST. J., Feb. 14, 2012, at C10 (describing the growth in big bank market share in business lending at the expense of smaller banks and attributing one possible cause to "bigger banks capitaliz[ing] on the fact that they received the most government assistance during the crisis and continue 
commentators have suggested that antitrust enforcement is becoming more critical in this arena. ${ }^{250}$ Smaller banking organizations have expressed similar concerns. ${ }^{251}$

As a major recent decision regarding the acquisition by Capital One of ING Direct reveals, the Fed clearly believes that traditional competitive analysis, in which it is difficult to demonstrate anticompetitive effects in the case of banking, remains applicable. ${ }^{252}$ Yet it is possible that the potential anticompetitive effects of large-scale banking are subtler than can be captured by this traditional analysis. ${ }^{253}$

\section{Distorting Political Influence}

The sheer magnitude of economic power possessed by big banks, their ability to spend large sums lobbying both politicians and regulators, and their willingness to do so as reflected in the fact that their political spending has escalated dramatically, raises an obvious

to enjoy a cost-of-funding advantage"). For an early empirical study suggesting negative impacts on smaller banks, see Gary Whalen, The Impact of the Growth of Large, Multistate Banking Organizations on Community Bank Profitability 29 (Office of the Comptroller of the Currency, OCC Econ. Working Paper No. 2001-5, 2001), available at http://www.occ.treas.gov/publications/publications-by-type/economics-

working-papers/2008-2000/wp2001-5.pdf.

${ }^{250}$ See, e.g., Scherer, supra note 227, at 273-74.

251 See Press Release, Indep. Cmty. Bankers of Am., ICBA Recommends Moratorium on Acquisitions and Mergers for Financial Institutions \$100 Billion and Up (Sept. 20, 2011), available at http://www.icba.org/ news/newsreleasedetail.cfm?ItemNumber $=92403$.

${ }^{252}$ FED. RESERVE Sys., ORDER APPROVING THE ACQUiSITION OF A SAVINGS ASSOCIATION AND NONBANKING SUBSIDIARIES 8-10 (2012) [hereinafter CapOne Ruling], available at http:/www.federalreserve.gov/ newsevents/press/orders/order20120214.pdf.

${ }^{253}$ For a thoughtful review addressing the dilemma of reducing U.S. bank size to restore domestic competition while at the same time preserving competitive capability in the face of foreign big bank competition, see Sharon E. Foster, Too Big to Fail-Too Small to Compete: Systemic Risk Should Be Addressed Through Antitrust Law But Such a Solution Will Only Work If It Is Applied on an International Basis, 22 FLA. J. INT'L L. 31, 35 (2010); see also Aaron Edlin \& Richard Gilbert, It Works for Mergers, Why Not for Finance?, ECONOMIST'S VOICE, Apr. 2010, at 1, 1-2 (proposing an "intermediate approach" to financial regulation, centered on self-reporting by firms "whose liabilities exceed some size threshold"). 
question whether their presence has begun seriously to distort the political and regulatory process. ${ }^{254}$

Political considerations will always loom large when any very large corporation threatens to fail. The controversies surrounding the General Motors and Chrysler bailouts provide nonfinancial examples. ${ }^{255}$ More insidious, however, is the disproportionate influence on public perceptions and political behavior that can be exercised on a continuous basis by the ultralarge corporations, including big banks. Such ultra-large corporations have huge corporate and political action committee ("PAC") reserves available for marketing and political contributions, and their executives are significant political contributors. ${ }^{256}$ The lobbyists they

${ }^{254}$ See, e.g., Lawrence Baxter \& Terence Hynes, Resolved, the Federal Government Should Ensure that No Firm Is Too Big to Fail, in DeBATING Reform: Conflicting Perspectives on How To Fix the American PoliticAl SYstem 297, 303-04 (Richard J. Ellis \& Michael Nelson eds., 2011) ("[Large corporations] are also able to exercise a disproportionate influence on public perceptions and political behavior because they have a huge reservoir of funds for marketing and political contributions and because the leaders of large corporations and the lobbyists they hire are very influential in the formulation of public policy."); Scherer, supra note 227, 268-69 ("[F]inancial institutions that are large in absolute size may have deep and well-filled pockets with which they can among other things hire lobbyists, support individual political parties and election candidates, and, under the recent Supreme Court reinterpretation of the U.S. Constitution's first amendment, mount advertising campaigns in direct support of or opposition to election candidates.").

${ }^{255}$ The political controversy surrounding the bailout of General Motors and Chrysler has continued for almost four years. See Brett Logiurato, Bush Defends Auto Bailouts Amid Growing Political Debate: 'I'd Do It Again,' INT'L BuS. TIMES (Feb. 7, 2012, 4:36 PM), http://www.ibtimes.com/ articles/294659/20120207/george-bush-obama-romney-bailout-eastwoodcommercial.htm (reporting that, if given the choice again, former President Bush would opt to provide bailout funds to the automobile industry).

${ }^{256}$ See Lee Drutman, On FIRE: How the Finance, Insurance and Real Estate Sector Drove the Growth of the Political One Percent of the One Percent, SunLight Foundation (Jan. 26, 2011, 12:01 AM), $\mathrm{http} / / /$ sunlightfoundation.com/blog/2012/01/26/on-fire-how-the-financeinsurance-and-real-estate-sector-drove-the-growth-of-the-political-onepercent-of-the-one-percent/ (describing how the wealth of financial industry leaders has enabled them to influence politics); see also John Tomasic, Study: Finance Industry Execs Rule Political Spending, AM. INDEP. (Jan. 27, 2012, 4:51 PM), http://www.americanindependent.com/209881/study- 
hire are very influential in shaping public policy, and they are able to buttress their lobbying power through expert industry associations. ${ }^{257}$ The financial industry has also benefited from lobbying by supportive organizations such as the U.S. Chamber of Commerce. ${ }^{258}$ Many very large companies, including financial institutions that received formal or de facto bailouts, such as Bank of America, Citigroup and Goldman Sachs, make greater political contributions than some other whole industries combined. ${ }^{259}$ Key politicians also receive large individual contributions from the industry, ${ }^{260}$ and,

finance-industry-execs-rule-political-spending (providing further analysis of the Sunlight Foundation figures, which show a $700 \%$ increase in political contributions from financial industry executives in the past thirty years).

${ }^{257}$ Well-known examples of such organizations are the Financial Services Roundtable and the American Banking Association, among others.

${ }^{258}$ The U.S. Chamber of Commerce has been a vocal opponent of the Consumer Financial Protection Bureau and has repeatedly called into question the Bureau's authority. See Kate Davidson, Chamber of Commerce Challenges CFPB's Authority, AM. BANKER (Aug. 16, 2011, 3:27 PM), http://www.americanbanker.com/issues/176_159/chamber-of-commercechallenges-cfpb-authority-1041238-1.html (reporting that the U.S. Chamber of Commerce refused to recognize the CFPB's authority to issue rules without a permanent director). For the scale of lobbying by the Chamber of Commerce, see Ctr. for Responsive Politics, Lobbying Spending Database U.S. Chamber of Commerce, 2011, OPENSECRETS.ORG, http://www. opensecrets.org/lobby/clientsum.php?id=D000019798\&year=2011 (last visited Mar. 19, 2012) (reporting total lobbying expenditures of more than $\$ 66$ million, including lobbying expenditures by parent and subsidiary organizations).

${ }^{259}$ For a breakdown of political giving by industry, see Ctr. for Responsive Politics, Interest Groups, OPENSECRETS.ORG, http://www.opensecrets.org/ industries/ (last visited Mar. 19, 2012). For the most recent individual bank contributions, see Ctr. for Responsive Politics, Finance/Insurance/Real Estate, OPENSECRETS.ORG, http://www.opensecrets.org/industries/indus. php? Ind=F (last visited Mar. 19, 2012).

${ }^{260}$ See, e.g., Linette Lopez, Bank by Bank, Here Are Wall Street's Favorite Politicians, BUS. INSIDER CLUSTERSTOCK (Jan. 20, 2012, 10:04 AM), http://www.businessinsider.com/bank-by-bank-here-are-wall-streetsfavorite-politicians-2012-1?op=1 (listing political candidates who received the most money from individual large banks in 2011-12, using OpenSecrets.org data). 
perhaps even more importantly, large financial companies are able to muster great resources for pressuring regulatory actions. ${ }^{261}$

This ability to influence the outcome of public policy at both the congressional and regulatory level is not in itself inappropriate. In principle, it is a necessary part of an effective democratic process in a highly technical world. Yet Charles Lindblom aptly described this ability to influence the political and public policy process as the "privileged position of business." 262 The question is whether this privilege has reached the point at which we can no longer assume that either Congress, the President or the regulators are able to make well-balanced decisions for the general welfare, rather than decisions that improperly favor the industry over the general public to the detriment of the proper functioning of markets and the fair allocation of the costs of the risks generated by big banks. ${ }^{263}$

\section{Costs of Regulation and Supervision}

There is almost universal agreement, even among bankers, ${ }^{264}$ that appropriate regulation and supervision ${ }^{265}$ of big banks is

${ }^{261}$ See, e.g., Kimberley D. Krawiec, Don't 'Screw Joe the Plummer:' The Sausage-Making of Financial Reform 19-27 (Nov. 11, 2011) (unpublished manuscript), available at http://ssrn.com/abstract $=1925431$; see generally Baxter, supra note 35.

262 Charles E. Lindblom, Politics AND Markets: The World's POLITICAL-ECONOMIC SYSTEMS 172 (1977).

${ }^{263}$ For an analysis of the damaging effects of such influence when the scale of political influence-peddling increases and the degree of corporate accountability for the political funding decisions becomes increasingly diluted, see Jennifer S. Taub, Money Managers in the Middle: Seeing and Sanctioning Political Spending After Citizens United, 15 N.Y.U. J. LEGIS. \& PUB. POL'Y (forthcoming Apr. 2012), available at http://ssrn.com/ abstract=2007121.

${ }^{264}$ See Donna Borak, Citi's Pandit Calls for Greater Consumer Regulation, AM. BANKER (Sept. 23, 2011, 4:42 PM), http://www.americanbanker. com/issues/176_186/consumer-protection-panditi-citigroup-simplicity-card1042497-1.html (reporting that Citi CEO Vikram Pandit favors increasing financial regulation protecting consumers); Lorie Konish, Citigroup's Pandit Calls for More Derivatives Regulation, AM. BANKER (Nov. 8, 2011, 12:27 PM), http://www.americanbanker.com/news/citigroup-panditderivatives-regulation-1043897-1.html (reporting that Mr. Pandit favors regulating derivatives and shadow banking).

265 As used in this article, "regulation" refers to the rules (legislation, regulations and "guidance") establishing what banks can and cannot do, and 
essential for maintaining financial stability and monitoring risks, protecting consumers, maintaining efficient markets and ensuring fair competition among institutions. Of course, debate rages around precisely what such regulation and supervision should be. Nevertheless, whatever form it takes, the costs of regulating and supervising LCFIs (to use the regulators' term) are very considerable and becoming commensurately more complex as such institutions grow in size and complexity themselves. It is commonplace to hear the assertion that LCFIs have in fact simply become "too complex to regulate."266 There are many reasons why.

"supervision" refers to the ongoing monitoring, supervision and examination of specific financial institutions and specific actions (including enforcement) taken by regulators to address specific problems. Conceptually, regulation and supervision are distinct: each constitutes complementary techniques for detecting and addressing business activities that threaten the safety, soundness and solvency of financial institutions. Each has its advantages and disadvantages. Regulation sets out rules upfront, such as capital and liquidity levels, leverage ratios, loan exposures, collateralization requirements, boundaries between permissible and impermissible products and services, accounting treatment and reporting. Supervision monitors the continuing activities of particular institutions to ascertain compliance, how institutions are being managed and whether they are being managed safely. There is a subtle difference between a "regulatory" approach and a "supervisory" one, in that the former tends to focus on compliance with advance rules and regulations, whereas the latter focuses more on the actual risk generated by the specific portfolio of a bank and its current circumstances. In practice, however, these are differences of timing and degree: "regulation" and "supervision" tend to merge in their practical application because of the huge vagaries of specific circumstances and the need for discretionary evaluation. On the long-standing debate between rules-based and prudential-based financial regulation, see Julia Black, Forms and Paradoxes of Principles Based Regulation 8 (London Sch. of Econ. \& Pol. Sci., LSE Law, Society and Economy Working Papers No. 13/2008, 2008), available at http://ssrn.com/abstract=1267722 (describing the rhetoric of "principles-based regulation" as "a re-framing of the regulatory relationship from one of directing and controlling to one based on responsibility, mutuality and trust").

${ }^{266}$ See, e.g., Peter Fox-Penner, Too Big to Regulate?, BASEline SCENARIO (Jan. 16, 2010), http://baselinescenario.com/2010/01/16/too-big-to-regulate/ ("For purely practical reasons, organizational complexity also makes regulation ineffective. As businesses get successively more complex and varied business structures, the ability of regulatory agencies to understand the company's financial position simply fades away. It is well-documented, 


\section{Evolving Dimensions of Risk}

The risks generated by modern large-scale finance have become extraordinarily complex. In traditional banking, the most important risk that needed to be monitored was credit risk. Bank regulators were able to draw their own supervisors from the pool of expertise developed within the loan administration departments of banks because credit underwriting was well understood.

Now, however, credit risk is only one aspect of a cluster of risk management and regulatory concerns. Whole new categories of risk have become crucially important, both to the management of the institutions themselves and the supervision of these institutions by regulators. ${ }^{267}$ Proliferation of new products, particularly structured securities and complex derivatives, and connections among financial institutions as a result of complex product innovation within a globalizing environment is now an inherent part of the business of big banks. ${ }^{268}$ Points of vulnerability and potential failure have escalated, and regulators and corporate risk officers collectively have, rapidly and often reactively, had to address burgeoning dimensions of risk management and supervision.

The most important newer areas of institutional risk management and regulation are market risk and operational risk. Market risk ${ }^{269}$ attracted earlier attention than operational risk because

for example, that Enron built a financial structure so complex that regulators could never understand what it was up to, even following its downfall.").

${ }^{267}$ For a review of the range of risks for which modern risk management is developing, see Kevin Buehler et al., The New Arsenal of Risk Management, HARV. Bus. REV., Sept. 2008, at 93.

268 See, e.g., Steven L. Schwarcz, Regulating Complexity in Financial Markets, 87 WASH. U. L. REV. 211, 216-20 (2009) (describing the complexity associated with many asset-backed securities and other structured finance products).

269 Market risk is the "risk of losses in on and offbalance-sheet [sic] positions arising from movements in market prices, including interest rates, exchange rates and equity values." Supervisory Treatment of Market Risks, BANK FOR INT'L SETTLEMENTS, http://www.bis.org/publ/bcbs11a.htm (last visited Apr. 9, 2012); see also BASEL COMM. ON BANKING SUPERVISION, INTERNATIONAL CONVERGENCE OF CAPITAL MEASUREMENTS AND CAPITAL STANDARDS: A REVISED FRAMEWORK 157 (2006) [hereinafter, BASEL, REVISED FRAMEWORK], available at http://www.bis.org/publ/bcbs128.htm (applying a nearly identical definition for "market risk" and stating that risks related to "interest rate related instruments and equities in the trading 
of its centrality to the securities and investment banking industry. Operational risk ${ }^{270}$ is now increasingly important because it acquires acute significance within the context of the management and regulation of complex financial activity. Yet the scale, complexity and sophistication of operational risk remain relatively new phenomena for both big banks and regulators. Only in the past decade has the subject really begun to attract serious managerial attention, so it is not surprising that operational risk has also only recently been subjected to detailed articulation by regulators.

\section{Basel II and the Failures of Institutional Risk Regulation}

Before the Crisis, domestic and international regulators maintained their focus primarily on the risks generated by individual institutions, not the system as a whole. To address market and credit

book" and "foreign exchange risk and commodities throughout the bank" are subject to the requirement). After earlier focusing almost entirely on credit risk, the Basel Committee introduced the additional concept of market risk in 1996 and, in doing so, prompted an accelerating trend toward increased reliance on quantitative models as the means of supervision. The Committee amended its 1988 Capital Accord by issuing a Market Risk Amendment. See id. at 263. This Amendment permitted regulators of banks to rely upon proprietary in-house value-at-risk ("VaR") models in order to determine the amount of capital charge to be assessed against assets. On VaR, see generally PHILIPPE JORION, VALUe AT RISK: THE NEW BENCHMARK FOR MANAGing FinANCial Risk (2d ed. 2001). Professor Jorion defines VaR as "the quantile of the projected distribution of gains and losses over a target horizon" and provides the following description of its application: "If $c$ is the selected confidence level, VAR corresponds to the $1-c$ lower-tail level. For instance, with a 95 percent confidence level, VAR should be such that it exceeds 5 percent of the total number of observations in the distribution." Id. at 22.

270 "Operational risk" is defined as the "risk of loss resulting from inadequate or failed internal processes, people and systems or from external events", and it includes legal risks, such as liabilities for damages or damage to reputation arising from failures in the conduct of business. See BASEL, REVISED FRAMEWORK, supra note 269, at 144. For a rare detailed discussion, see Tyson Macaulay, Convergence of Operational and Credit Risks: Additivity of Risk - Paper I of III (Feb. 2008) (unpublished manuscript), available at http://www.tysonmacaulay.com/. For a review of some of the sources of operational risk specific to LCFIs, see supra text accompanying notes 125-134. 
risk, risk managers within individual big banks turned to quantification ("quant") models designed to measure the risks reflected in the portfolios and operations of their specific institutions. ${ }^{271}$

The regulators, in turn, aligned their own regulatory and supervisory techniques with those models. This is illustrated quite concretely by the evolution of the risk management framework developed by the Basel Committee on Banking Supervision ("BCBS"), ${ }^{272}$ which has driven the process for "internationally active" banks (including nearly all significant LCFIs and certainly all big banks).

Driving the evolution of quantified risk management and the corresponding approach to modern bank regulation are two central principles. The first is estimation of expected losses on very largescale portfolios. Banks know that some loans, for example, will go bad; they just do not know which ones. They can, however, estimate fairly reliably over large numbers the losses that might be expected on an aggregate basis, taking into account past experience and current conditions, by using quant models. The second principle is ensuring that banks have reserves or "provisions" for absorbing the expected default losses when they actually occur and capital buffers for absorbing unexpected losses and avoiding bankruptcy that might otherwise follow from those losses. The combined application of these principles forms the core of the framework for large-scale financial organization regulation under the Basel approach.

The principle of drawing from the internal risk management systems of financial institutions for signals upon which regulatory assessments could themselves be drawn was widely hailed as a significant innovation. Yet it was also, in effect, a fundamental delegation of regulatory judgment from the regulators to the developers and operators of the internal systems, leaving regulatory certification as the primary vehicle for ensuring that financial

\footnotetext{
${ }^{271}$ See Gillian Tett, Fool's Gold: How the Bold Dream of a SMall Tribe at J.P. Morgan Was Corrupted by Wall Street GreEd AND UNLEASHED A CATASTROPHE 130-33 (2009) (describing the use and exploitation of derivatives models).

${ }^{272}$ On the Basel Committee on Banking Supervision, see generally About the Basel Committee, BANK FOR INT'L SETTLEMENTS, http://www.bis.org/ bcbs/about.htm (last visited Apr. 10, 2012).
} 
institutions are operating safely. ${ }^{273}$ The inevitable result was to transfer the focus of risk management and supervision onto IT systems and quant models, ${ }^{274}$ many of which turned out to be hopelessly inadequate and undeveloped for the task. ${ }^{275}$

In an effort to produce more sophisticated capital measurement for banks and encourage greater awareness and sophistication in risk management by banks themselves, the BCBS developed and, in 2004, published a Revised Framework on International Convergence of Capital Measurement and Capital Standards ("Basel II"). ${ }^{276}$ Pillar 1 of Basel II is designed to instruct banks how to assess credit, market and operational risk. Pillar 2 instructs bank supervisors how to evaluate the systems and controls

${ }^{273}$ See Erik F. Gerding, Code, Crash, and Open Source: The Outsourcing of Financial Regulation to Risk Models and the Global Financial Crisis, 84 WASH. L. REV. 127, 129-30 (2009) (arguing that "financial regulators delegated or outsourced to . . . computer-based risk models the responsibility of regulating a wide range of risk transfers in the economy from consumer finance to global financial markets.").

${ }^{274}$ Regulators have refined the overall approach throughout the past decade. They now measure discreet risks by means of complex formulae and models. Regulators assess systems, not the actual business decisions, for reliability and adequacy to determine the regulatory capital that complex banks must hold. Capital charges are then assessed in light of expected losses estimated by the models, and these are factored into the evaluation of the capital adequacy for specific institutions. Risk factors are assigned to specific classes of assets to either discount or inflate their expected impact on the capital buffer. For a concise exposition, see HEIDI MANDANIS SCHOONER \& Michael W. TAYLOR, Global BANK REgulation: PRINCIPLES AND POLICIES 131-43 (2010).

${ }^{275}$ See Gerding, supra note 273, at 134 (noting the failure of risk models to foresee the subprime mortgage crisis).

276 BASEL COMM. ON BANKING SUPERVISION, INTERNATIONAL Convergence of Capital Measurements and Capital Standards (2004) [hereinafter INTERNATIONAL CONVERGENCE OF CAPITAL MEASUREMENTS AND CAPITAL STANDARDS], available at http://www.bis.org/publ/bcbs107.pdf?noframes=1; see also SCHOONER \& TAYLOR, supra note 274, at 147-64 (providing an overview of Basel II); DANIEL K. TARULlo, BANKING ON BASEl: THE FUtURE OF INTERNATIONAL FINANCIAL REGULATION 100-04 (2008) (describing the origins of Basel II). BCBS published a "comprehensive version" in June 2006. See generally BASEl COMM. ON BANKING SUPERVISION, INTERNATIONAL CONVERGENCE OF CAPITAL MEASUREMENT AND CAPITAL STANDARDS (2006), available at http://www.bis.org/publ/bcbs128.pdf. 
developed by bankers under Pillar 1 and any other that ought to be factored into the overall risk assessment. ${ }^{277}$ Pillar 3, although still in various stages of development and implementation, is designed to add the component of external market discipline by promoting greater transparency of risk through better company disclosure of capital structure, capital adequacy, Pillar 1 risks and interest rate risks to which the company is exposed. ${ }^{278}$ An important basic limitation of the overall approach is its heavy dependence upon quant models in both Pillar $1^{279}$ and Pillar 2. ${ }^{280}$

277 The United States banking regulators have now jointly implemented Pillars 1 and 2. See generally OCC Minimum Capital Ratios: Issuance of Directives, 12 C.F.R. pt. 3 (2011); FRB Membership of State Banking Institutions in the Federal Reserve System (Regulation H), 12 C.F.R. $\S 208$ (2011); FRB Bank Holding Companies and Change in Bank Control (Regulation Y), 12 C.F.R. §225 (2011); FDIC Capital Maintenance, 12 C.F.R. § 325 (2011); OTS Subordinate Organizations, 12 C.F.R. $§ 559$ (2012); OTS Lending and Investment, 12 C.F.R. § 560 (2012); OTS Savings Associations- Operations, 12 C.F.R. § 563 (2012); OTS Capital, 12 C.F.R. § 567 (2012); see also generally Pillar 1 final rule: Risk-Based Capital Standards: Advanced Capital Adequacy Framework Basel II, 72 Fed. Reg. 69,288 (Dec. 7, 2007); Supervisory Guidance: Supervisory Review Process of Capital Adequacy (Pillar 2) Related to the Implementation of the Basel II Advanced Capital Framework, 73 Fed. Reg. 44,620 (July 15, 2008).

278 See International Convergence of Capital Measurements and CAPITAL STANDARDS, supra 276, at 226. For recent revisions, see BASEL COMM. ON BANKING SUPERVISION, ENHANCEMENTS TO THE BASEL II FRAMEWORK 28-30 (2009), available at http://www.bis.org/ publ/bcbs 157.pdf. The interrelationship between determinations under Pillar 1 and Pillar 2 is considerably complex, and its entire methodology is subject to strong criticism. Governor Tarullo mounts three objections against the Basel Framework: the compliance costs and supervisory limitations within domestic systems outweigh any benefit that might be gained from an international framework; a domestic process can generate more effective rules; and a simpler framework might be more effective in permitting domestic regimes to develop optimal rules. See TARULLO, supra note 276, at 225 (briefly summarizing Tarullo's arguments against the Basel Framework, which are elaborated on in various preceding chapters).

${ }^{279}$ As an overview of Pillar 1, large and internationally active banks (socalled "core banks" in the United States), with balance sheet assets of at least $\$ 250$ billion or on-balance sheet foreign exposure of $\$ 10$ billion or more, will submit to an "advanced measurement approach" (AMA) for calculating operational risk. Risk-Based Capital Standards: Advanced Capital Adequacy Framework- Basel II, 72 Fed. Reg. 69,288, 69,391 (2007) 
The Basel framework, with its focus on detailed assumptions and formulae of quant models, requires mathematical precision and predictability. As the crisis indicates, however, these models do not necessarily capture risks sufficiently, guarantee correct initial assumptions or provide a sufficiently broad basis on which to measure actual operational risks. The models focus on aggregate performance, but do not adequately measure how the various parts of a complex enterprise function together or interact over time. Nor do the models adequately target individual vulnerabilities, which are potentially very damaging. While aggregate predictors might produce

(codified at 12 C.F.R. pt. 3). The Framework and, to an even greater extent, the U.S. rules implementing the Framework, articulate detailed quantitative and qualitative guidelines. For example, to measure credit risk, financial institutions may use an internal ratings-based (IRB) approach, which also relies on the company's own risk assessments. $I d$. at 69,288 . Furthermore, the rules identify seven categories of operational risk: internal fraud; external fraud; employment practices and workplace safety; clients products and business practices (e.g. liability for fiduciary violations); damage to physical assets; business disruption and system failures; and execution, delivery and process management (e.g., loss as a result of a failed wire transfer). Id. at 69,314. In addition to identification, Pillar I helps to generate estimates of forward-looking operational risk exposure through event capture and loss assessment systems and quantification systems. The bank's processes must "reflect the scope and complexity of its business lines, as well as its corporate organizational structure. Id. at 69,315. But see SCHOONER \& TAYLOR, supra note 274, at 152-59 (criticizing the Framework on the grounds that "[t]he internal ratings-based (IRB) approaches are a much more radical departure from Basel I than is the Standardized Approach. Whereas the Standardized Approach is essentially a refinement of Basel I's risk categories, the IRB approaches rely on banks' internal estimates of the key risk elements that determine their required capital. Moreover, the IRB approaches involve a much more refined deconstruction of credit risk into its component parts.").

${ }^{280}$ Pillar 2 of the Framework focuses on the quality of the internal assessment by a company of its credit, markets, operations and other risks (e.g. liquidity risk). Furthermore, the Pillar evaluates the relationship of the risk. Under the U.S. implementing regulations, the Pillar requires larger banks to use an Internal Capital Adequacy Assessment Process (ICAAP). Although regulators can impose additional capital charges to account for risks not captured solely under the Pillar 1 framework, the institution's own methods of controlling its risks are the primary driver of its supervision. See generally Supervisory Guidance: Supervisory Review Process of Capital Adequacy (Pillar 2) Related to the Implementation of the Basel II Advanced Capital Framework, 73 Fed. Reg. at 44624-28. 
consistent results in theory, they do not account for factors that are highly relevant but inherently non-quantifiable. Good managers perform better than bad managers. The difference can show up quickly in a crisis, and this difference, within the context of financial services, can be devastating. Black swans and once-in-a-century events are not to blame. ${ }^{281}$ Many of the proximate triggers to the crisis derive from such commonplace maladies as greed, criminality, sheer stupidity and the organizational dysfunctions already described. ${ }^{282}$ Meanwhile, the moral hazard inherent in modern systems of banking and finance serves only to dangerously exaggerate these defects in corporate performance. ${ }^{28}$

Reliance on aggregate models, whether effective or not, might be reasonable in a mature, relatively predictable industry that is unlikely to have its mistakes amplified through systemic interconnection. In the volatile and rapidly innovating world of financial services, however, such reliance has proven downright dangerous. One of the principle quant vehicles for measuring risk is VaR. Yet, as expert Pablo Triana concluded, "VaR's problem is one of original sin: trying to measure financial risk with precision may be utterly hopeless." 284 For example, quant models generate substantially greater risk by adding systemic momentum to activities that should in fact be reigned in near the top of bubbles. ${ }^{285}$ When

281 Alan Greenspan uses the term "hundred year flood" in a different way. Rather than as an excuse for not seeing the crisis coming, he emphasizes that financial institutions should expect wide scale help from the government in only rare events. Alan Greenspan, Chairman, Bd. of Governors of the Fed. Reserve, Remarks before the Journal of Financial Services Research and the American Enterprise Institute Conference: Technology and Financial Services (Apr. 14, 2000), available at http://www.federalreserve.gov/boarddocs/speeches/2000/20000414.htm.

${ }^{282}$ See supra text accompanying notes 125-134.

${ }^{283}$ For a discussion about moral hazard in general, see Tom Baker, On the Genealogy of Moral Hazard, 75 TEX. L. REV. 237 (1996). On its relevance to financial regulation, see, e.g., SCHOONER \& TAYLOR, supra note 274, at 60-66 (providing an overview of moral hazard and financial regulation).

${ }^{284}$ PABLO TRIANA, Introduction to THE NUMBER THAT KILlED Us: A STORY Of Modern Banking, Flawed Mathematics, AND A Big Financial CRISIS, at xiii (2012).

${ }^{285}$ Id; see also Ed Blount, Searching for New Paradigms at BIS, ABA BANKING J., July 2008, at 7 (noting that central bankers "seem to have concluded that banks that relied on VaR tended to operate in ways which exaggerated the banking systems' natural 'procyclicality."'). 
businesses that are exceptionally complex, interconnected and partially subsidized are combined with quant models that are designed to manage and regulate such businesses, the results have proven disastrous. Indeed, one of the supposed high priests of "modern" bank regulation, Mr. Alan Greenspan, identified one of the major problems in the recent financial crisis to be "the virtual indecipherable complexity of a broad spectrum of financial products and markets that developed with the advent of sophisticated mathematical techniques to evaluate risk." 286

Despite all their sophistication and complexity, the modeling and monitoring systems developed under the Basel frameworks have inadequately addressed comprehensive risk management and its regulation.

\section{The Dodd-Frank Act and Basel III}

The Dodd-Frank Act in the United States, and modifications to the Basel Framework internationally, attempt to make up for the failures of the Basel II and domestic regulatory frameworks. The Dodd-Frank Act intensified the focus on U.S. macro-prudential regulation, which had already been gaining momentum. In particular, the Act clustered the heads of existing financial regulatory agencies into a new Financial Stability Oversight Council ("FSOC") to identify institutions that create threats to financial stability, decide whether to subject them to enhanced supervision by the Fed, and to consider new policies for addressing systemic threats. ${ }^{287}$ Congress also created the Office of Financial Research ("OFR") to assist the

286 Alan Greenspan, The Crisis 11-12 (Apr. 15, 2010) (unpublished manuscript), available at http://www.brookings.edu/ /media/Files/ Programs/ES/BPEA/2010_spring_bpea_papers/spring2010_greenspan.pdf (leveling his mea culpa at the very theoretical basis upon which these models were built as the origin of massive regulatory failure: "How could it have failed on so broad a scale? The paradigm that spawned Nobel Prize winners in economics was so thoroughly embraced by academia, central banks, and regulators that by 2006 it became the core of global regulatory standards (Basel II).”).

287 See Dodd-Frank Act, Pub. L. No. 111-203, § 111(b), 124 Stat. 1376, 1392-93 (2010) (to be codified at 12 U.S.C. $§ 5321$ (b)) (creating the FSOC with ten different regulators and five observers to follow cumbersome procedures, resembling the old adage that a camel is a horse designed by a committee). 
FSOC by collecting data and organizing it into usable information. ${ }^{288}$ This bold objective, the success of which will be tested over the next few years, might be less effective than sophisticated LCFI supervisors interacting with LCFIs on a daily basis.

Congress also augmented the powers of existing financial regulators. Regulators complained that they lacked the power to deter ${ }^{289}$ the financial institutions that were undertaking too much risk. ${ }^{290}$

At the same time, the BCBS and the G20's Financial Stability Board ("FSB") ${ }^{291}$ have made extensive efforts to improve

${ }^{288}$ See id. § 152(a) (to be codified at 12 U.S.C. $§ 5342$ (a)) (creating the Office of Financial Research ("OFR"), which faces significant challenges including the task of developing genuinely usable data that will enable the FSOC to carry out its mission of assessing institutions); see also, e.g., William Alden, For Wall Street Overseer, Progress Comes at a Crawl, N.Y. TIMES DEALB\%K (Jan. 3, 2012, 7:55 PM), http://dealbook. nytimes.com/2012/01/03/for-wall-street-overseer-progress-comes-at-aslow-crawl/ (describing the slow start OFR faced because of a divisive Congress); Tom Braithwaite, Finance: Elusive Information, FIN. TIMES (Feb 15, 2011, 10:25 PM), http://www.ft.com/intl/cms/s/0/aef82036-394611e0-97ca-00144feabdc0.html\#axzz1nz91oFRi (outlining the challenges involved in collecting, coding and extracting usable information from a potentially colossal mountain of data).

${ }^{289}$ It should also be noted that they had themselves as much to blame. As very senior former regulators have recently observed:

The global financial crisis was not simply the result of too little regulatory power, unclear lines of regulatory authority, toxic financial innovations, or unsustainable international capital flows. All these were contributing factors. But, through acts of commission and omission, major financial regulatory institutions repeatedly designed and maintained policies that increased the fragility of the financial system ....

James R. Barth, ET Al., Guardians of Finance: Making Regulators WORK FOR US 231 (2012).

${ }^{290}$ Sheila C. Bair, Chairman, Fed. Deposit Ins. Corp., Statement of Sheila C. Bair, Chairman, Federal Deposit Insurance Corporation on the Causes and Current State of the Financial Crisis before the Financial Crisis Inquiry Commission (Jan. 14, 2010) (transcript available at http://www.fdic.gov/ news/news/speeches/chairman/spjan1410.html).

${ }^{291}$ Overview, Fin. STABILITY BOARD, http://www.financialstabilityboard. org/about/overview.htm (last visited Apr. 10, 2012). 
and extend the international coordination of financial regulation in order to secure greater global financial stability. ${ }^{292}$ In particular, regulators have developed a comprehensive set of reform measures called "Basel III" since the Crisis. ${ }^{293}$ Basel III's principle objectives are to improve the banking sector's ability to absorb shocks, improve risk management and governance and strengthen bank transparency and disclosures. Basel III strengthens Pillar 1 of Basel $\mathrm{II}^{294}$ considerably in several major respects. ${ }^{295}$

Bankers heavily criticize Basel III for imposing severe restrictions that are too severe to allow for recovery in the face of weak global economic indicators. ${ }^{296}$ Also, from an American perspective, Basel III arguably tips the playing field in favor of the LCFIs in other countries, particularly Europe. On the other hand, Basel III critics argue that it may be too lenient, vague and slow in implementation. At this stage, one positive element is that the framework focuses on the right elements for successful regulation in an extraordinarily complex system of systems. ${ }^{297}$ Time will tell whether Basel III strikes a sufficient balance between severity and leniency.

${ }^{292}$ See BRUMMER, supra note 234, at 213-53 (describing efforts to achieve international coordination of financial regulations).

${ }^{293}$ International Regulatory Framework for Banks (Basel III), BANK FOR InT'L SETTLEMENTS, http://www.bis.org/bcbs/basel3.htm (last visited Mar. 2, 2012).

${ }^{294}$ See supra text accompanying note 276.

${ }^{295}$ First, regulators increase capital buffers and the quality of capital over a phased period, including the addition of global liquidity standards to supplement the capital buffers. Second, regulators broaden the coverage of risks associated with securitizations, trading and counterparties. Third, regulators introduce a non-risk-weighted leverage ratio as a backstop to the risk-based capital requirements of Basel II. Finally, the Financial Stability Board will identify global systemically important financial institutions (GSIFIs) and provide standards to be phased in over time, including the need to secure additional loss absorbency, or "surcharges," through even higher capital requirements. See generally BASIL COMM. ON BANKING SUPERVISION, BASEl III: A GlOBAL REgUlatory FrameWORK FOR MORE RESILIENT BANKS AND BANKING SYSTEMS (2010), available at http://www.bis.org/publ/bcbs189_dec2010.pdf.

${ }^{296}$ Brooke Master \& Tom Braithwaite, Tighter rules on capital: Bankers Versus Basel, Fin. TIMES (October 2, 2011, 10:20 PM), http://www. ft.com/intl/cms/s/0/852fe7a4-eb4b-11e0-9a41-00144feab49a.html\#axzz1n $8 \mathrm{qE} 8 \mathrm{~T} 7 \mathrm{G}$.

${ }^{297}$ See infra text accompanying note 318. 


\section{Scale, Complexity and Financial Stability}

The lure to bankers of increased scale and scope as a means to greater efficiency, capability and innovation is matched by the escalating regulatory challenges associated with their organizations. Great scale might generate new benefits, but it also increases the complexity of big banks, their consequential potential impacts on the financial system, and the challenges imposed on policy makers and regulators. The big banking phenomenon has long assumed major systemic dimensions.

The notion of "systemic risk" has become central to discussions regarding the regulation of LCFIs around the world and is the rationale for creating the unwieldy FSOC. Regulatory focus has shifted away from attempting to minimize the risk of individual institutions failing - so called "micro-prudential" regulation-and toward new actions to minimize the systemic risks created by the possibility of failure of any one institution-so-called "macroprudential" or "financial stability" regulation. ${ }^{298}$

Systemic risk, rather than individual firm risk, endangers financial stability on all levels. Because big banks have become so large and tightly interconnected in the global financial system, their failure would have far greater impact to economic systems than the failure of other complex industrial conglomerates. ${ }^{299}$ Banks are much more highly interconnected than their counterparts in commerce and industry because of their high volume, frequency and multicounterparty transactions. Although the failure of a major industrial conglomerate can cause harm, sometimes even great harm, to an economy, ${ }^{300}$ a big bank failure or threatened failure creates the

298 See Dodd-Frank Act, Pub. L. No. 111-203, §§ 165, 115, 124 Stat. 1376, 1423-32, 1403-06 (2010) (to be codified at 12 U.S.C. $\S \S 5325,5365$ ) (outlining the requirements for "enhanced supervision"); see also Samuel Hanson et. al, A Macroprudential Approach to Financial Regulation 1 (Univ. of Chi. Booth Sch. of Bus., Working Paper No. 10-29, 2010), available at http://ssrn.com/abstract=1708173 ("In the aftermath of the crisis, there seems to be agreement among both academics and policymakers that financial regulation needs to move in a macroprudential direction."); Piet Clement, The Term "Macroprudential": Origins and Evolution, 2010 BIS Q. REV. 59, 59 (2010) ("In the wake of the recent financial crisis, the term 'macroprudential' has become a true buzzword.").

299 See supra text accompanying notes 193-207.

300 See, e.g., Janet E. Kerr, The Financial Meltdown of 2008 and the Government's Intervention: Much Needed Relief or Major Erosion of 
possibility that it will trigger cascading failures and threaten the stability and even survival of domestic and global financial systems. ${ }^{301}$ The collapse of Lehman Brothers in September 2008, the largest bankruptcy of a public company in the world, ${ }^{302}$ provides a graphic example. ${ }^{303}$

\section{A. Banks Are Indeed Still Special}

Twenty years ago, Mr. E. Gerald Corrigan posited that banks were different from other industries because they possess characteristics that distinguish them even from other financial institutions. ${ }^{304}$ Banks were "special," Mr. Corrigan argued, because they possess three key traits: they provide transaction accounts; they are the backup source of liquidity for all other institutions; and they are the transmission belts of monetary policy. ${ }^{305}$ These features justify the strong separation between banking and commerce. Moreover, the holding company model could uniquely expand into other financial services such as investment banking. Given their specialness, the full-scale public safety net should be extended only to banks.

In the two decades since Mr. Corrigan spoke, deregulation and other factors have caused various sectors of the financial industry to commingle. ${ }^{306}$ This led some commentators to suggest that the evolution of the industry has heavily diluted the "specialness" of

American Corporate Law? The Continuing Story of Bank of America, Citigroup, and General Motors, 85 ST. JOHN's L. REV. 49 (2011).

${ }^{301}$ See infra text accompanying notes 337-357.

${ }^{302}$ See Marissa Oberlander \& Cleve Jones, Top 10 All-Time Bankruptcies, FIN. TIMES (Nov. 28, 2011,5:23 PM), http://www.ft.com/intl/cms/s/0/ fe87129c-19b5-11e1-9888-00144feabdc0.html\#axzz1kxOyrNNk.

${ }^{303}$ See generally Stephen Foley, Crash of a Titan: The Inside Story of the Fall of Lehman Brothers, INDEPENDENT (Sept. 7, 2009), http://www.independent.co.uk/news/business/analysis-and-features/crashof-a-titan-the-inside-story-of-the-fall-of-lehman-brothers-1782714.html; 1 Report of Anton R. Valukas, Examiner, at 3, In re Lehman Brothers Holdings Inc., No. 08-13555 (Bankr. S.D.N.Y. Mar. 11, 2010).

304 E. Gerald Corrigan, Are Banks Special?, FED. RES. BANK MinN., http://www.minneapolisfed.org/pubs/ar/ar1982a.cfm (last visited Apr. 10, 2012). Mr. Corrigan was then President of the New York and Minneapolis Federal Reserve Banks and is currently a managing director at Goldman. ${ }^{305} \mathrm{Id}$.

${ }^{306}$ See supra text accompanying notes 106-113. 
banks. ${ }^{307}$ Yet, this evolution does not imply that the commingled financial industry is not itself "special." "308 Given the intense crossdependency of the industry as a whole, it seems more appropriate to broaden the "special" status across the full range of big banks, ${ }^{309}$ rather than maintain a distinction between banks and other financial institutions. Considering banks within the larger web of the financial services industry as a whole, it seems clear that almost all large financial firms are very different from other industries.

The dynamics of systemic failure evince that failures in other industries do not present the kind of system-wide threats that are posed by big bank failures, whether it be the failure of an investment bank, universal bank, traditional bank or some other form of very large specialty bank or financial enterprise. ${ }^{310}$ Banks and other financial institutions have become massively interconnected, such that the failure of any one institution, bank or otherwise, can wreak havoc to the system as a whole: the banking business (perhaps necessarily and inevitably) combines a potentially lethal cocktail of

${ }^{307}$ See, e.g., Jonathan R. Macey \& Geoffrey P. Miller, Nondeposit Deposits and the Future of Bank Regulation, 91 MicH. L. REV. 237, 272 (1992) ("The result will be further blurring of the distinctive characteristics that through the years have allegedly made banks "special" institutions deserving unique regulatory treatment.").

${ }^{308}$ See, e.g., E. Gerald Corrigan, Are Banks Special?: A Revisitation, FED. RES. BANK MINN., http://www.minneapolisfed.org/publications papers/pub_display.cfm?id=3527 (last visited Apr. 10, 2012) (arguing that banks are still special); Biagio Bossone, What Makes Banks Special? A Study of Banking, Finance and Economic Development (World Bank, Working Paper No. 2408, 1999) (supporting Corrigan's position by arguing that the banking industry is "special" and still distinct from its complementary nonbank financial partners).

${ }^{309}$ See supra text accompanying notes 57-72.

${ }^{310}$ See generally SCHOONER \& TAYLOR, supra note 274, at 35-49 ("The two main forms of these collective vulnerabilities are (a) the risk of a dominolike collapse in which the failure of one bank triggers the failure of many other banks and (b) the risk of asset price spirals."); MARKUS BRUNNERMEIER ET AL., CTR. FOR ECON. POLICY RESEARCH, INT'L CTR. FOR Monetary \& Banking Studies, Geneva Reports ON THE World ECONOMY 11, The Fundamental PRinciples of FinanCial Regulation 13-24 (2009) ("The fire-sale externality arises since each individual financial institution does not take into account the price impact its own firesales will have on asset prices in a possible future liquidity crunch. Hence, fire-sales by some institutions spillover, and adversely affect the balance sheet of others, causing a negative externality."). 
interconnectedness and moral hazard. ${ }^{311}$ Numerous failures, such as Lehman Brothers, ${ }^{312}$ Northern Rock ${ }^{313}$ and even MF Global (a hedge fund $)^{314}$ demonstrate the consequences of such failures in the United States, the United Kingdom and worldwide. The collapses of these financial institutions were major events precipitating the Financial Crisis. ${ }^{315}$

Corporate mistakes in the financial world can therefore have far reaching consequences to other institutions and ultimately to the taxpayer. Even if we can afford "learning mistakes" in other industries, ${ }^{316}$ we cannot afford those made by big banks. Yet we have increased the likelihood of such mistakes by allowing such institutions to grow rapidly within a climate of deregulation and by conducting forced marriages between them as they start to fail. ${ }^{317}$

${ }^{311}$ See, e.g., Steven L. Schwarcz, Systemic Risk, 97 GEO. L.J. 193, 248 (2008) (arguing that the growth of disintermediation calls for a greater focus on financial markets, rather than individual banks, in the context of systemic risk regulation).

${ }^{312}$ Many popular accounts of the failure of Lehman Brothers are now in publication. See, e.g., Report of Anton R. Valukas, supra note 125.

${ }^{313}$ See generally InTERnAL AUdiT Div., Fin. SeRvs. AUth., The SUPERVISION OF NORTHERN ROCK: A LESSONS LEARNED REVIEW (2008), available at $\mathrm{http}: / / \mathrm{www}$. fsa.gov.uk/pubs/other/nr_report.pdf.

314 See generally Barry Ritholz, MF Global Reveals You Are A Bank Counter-Party, BIG PICTURE (Feb. 15, 2012, 7:30 AM), http://www.ritholtz.com/blog/2012/02/volcker-rule-mfglobal-

bankcounterparty/.

315 The failures of MF Global in 2011 and Long Term Capital Management in 1998, two massive hedge funds, imposed considerable threats to the stability of big banks, thereby illustrating the heavy codependency of banks and other elements of the financial industry.

${ }^{316}$ See MCCRAW, supra note 92, at 253 (describing American tolerance for bankruptcy).

317 On these developments, a considerable literature has already accumulated. See, e.g., JOHNSON \& KWAK, supra note 248; SORKIN, supra note 130; supra text accompanying notes 208-220. 


\section{B. Complexity Science and New Perspectives on Risk Management}

The recent intensified focus on financial stability and the shift toward macro-prudential analysis, as embodied in both the Dodd-Frank $\mathrm{Act}^{318}$ and Basel III, ${ }^{319}$ has begun to incorporate a much more sophisticated understanding of systemic risk and the consequences of deep complexity in financial markets.

This more sophisticated approach is partly reflected in the Fed ruling on a merger proposal by the giant credit card company, Capital One. ${ }^{320}$ In its ruling, the Fed applied the new "financial stability" standard that the Dodd-Frank Act added as an approval hurdle in determining the "public benefit" of a proposed merger. ${ }^{321}$ This was the Fed's first major decision since the passage of the Dodd-Frank Act. The Fed, explicitly acknowledging the Basel Committee's approach to identifying global systemically important financial institutions ("G-SIFIs"), ${ }^{322}$ considered a variety of metrics in assessing the likelihood that the failure of the resulting organization might "inflict material damage to the broader economy." These metrics include both qualitative and quantitative measures addressing the:

- $\quad$ size of the resulting organization;

- availability of substitute providers in the event of subsequent failure;

- interconnectedness of the resulting organization with the banking or financial system;

\footnotetext{
${ }^{318}$ See supra text accompanying notes 287-290.

${ }^{319}$ See supra text accompanying notes 291-295.

${ }^{320}$ See CapOne Ruling, supra note 252, at 28 (considering a "financial stability factor" in the analysis of a bank merger's "public benefit").

${ }^{321}$ See Dodd-Frank Act, Pub. L. No. 111-203, § 604(e)(1), 124 Stat. 1376, 1601 (2010) (to be codified at 12 U.S.C. $\S 1843(\mathrm{j})(2)(\mathrm{A})$ ) (requiring that the Fed consider "the stability of the United States banking or financial system").

322 See CapOne Ruling, supra note 252, at 30 (comparing the Basel Committee's approach to G-SIFIs with the U.S. approach and acknowledging three differences); see also supra text accompanying note 295.
} 
- extent to which the resulting organization contributed to the complexity of the financial system;

- extent of the cross-border activities of the resulting organization;

- likely degree of difficulty in resolving a subsequent failure, such as the opacity of the resulting organization; and

- the operation of all these factors in combination. ${ }^{323}$

Whether the Fed struck the right balance in this analysis remains to be seen. But given the complexity elements of the financial system, as the following discussion will demonstrate, the Fed's approach seems eminently correct, heralds a whole new plateau in the regulation of financial mergers ${ }^{324}$ and is to be welcomed. ${ }^{325}$

${ }^{323}$ CapOne Ruling, supra note 252, at 28-30. Other required elements for the Fed's decision, such as competitive and community reinvestment analysis, are omitted from discussion here.

324 This appears to be the view of the industry as well. See, e.g., Tom Braithwaite, Dealmakers Worried by Fed's Tougher Oversight, FIN. TIMES, Feb. 28, 2012, at 22 (proposing that this "change in policy" reflects the end of an era of a permissive Fed); Maya Jackson Randall, Fed Raises Bar For Bank Deals, Wall St. J., Feb. 21, 2012, at C3 (mentioning some financial executives' surprise at the Fed's new level of scrutiny regarding proposed financial activity); Donna Borak, Capital One Approval Signals Trouble Ahead for Large Acquirers, AM. BANKER (Feb. 17, 2012, 6:02 PM), http://www.americanbanker.com/issues/177_34/capital-one-fed-reserve-hrodgin-cohen-systemic-risk-1046798-1.html (stating that the extended process preceding the Fed's Capital One ruling indicates a new era of heightened scrutiny for large financial institutions).

325 There appears to be growing empirical support for the view that size alone is not the appropriate measure for systemic risk. See, e.g., Chen Zhou, Are Banks Too Big to Fail? Measuring the Systemic Importance of Financial Institutions, INT'L J. CENTRAL BANKING, Dec. 2010, at 205, 23840 (2010) (concluding that size is not necessarily an indication of systemic importance). For the challenges of measuring systemic risk, see, e.g., Viral V. Acharya et al., Measuring Systemic Risk, in Regulating Wall STREet: The Dodd-Frank Act and The New Architecture of Global Finance 87 (Viral V. Acharya et al. eds., 2011) (providing methods of determining systemic risk). For rankings of the United States' and the world's most systemically risky financial institutions, see NYU Stern Systemic Risk 


\section{Essence of Complexity and Its Relevance to Financial Markets}

Complexity science is starting to show in precise ways exactly how larger banks can threaten systemic stability and pose increased dangers of widespread financial collapse. ${ }^{326}$ While a good deal of important commentary has focused on the highly complicated nature of modern financial products themselves, this is not the central concern: the central concern is how these products and the overall financial ecology, including financial institutions, financial infrastructure and even regulators themselves, interact together in a complex system.

Complexity is a dynamic concept. Financial products have often and long been exceptionally complicated, but not necessarily complex. ${ }^{327}$ It is the collection of financial systems as a whole- and the complexity of the participants themselves ("agents," as complexity scientists would call them) interacting within these systems $^{328}$ - that may well have reached unmanageable

Rankings, NYU STERN: THE VOLATILITY INSTITUTE, http://vlab.stern.nyu. edu/welcome/risk/ (last visited Mar. 12, 2012). At the time of writing, Deutsche was ranked the most systemically risky bank in the world.

${ }^{326}$ For an overview of complexity science and its application to social systems, including economic markets (which are highlighted as quintessential examples of complex adaptive systems), see generally Melanie Mitchell, Complexity: A Guided Tour (2009); NeIl Johnson, Simply COMPLEXITY: A CleAR GUIDE TO COMPLEXITY THEORY (2007); John H. Miller \& Scott E. Page, Complex Adaptive Systems: AN Introduction to Computational Models of Social LifE (2007). For a detailed description of how economic systems become complex, see Dirk Helbing, Systemic Risks in Society and Economics, in EMERGING RISKS Project Phase 1: Case Studies and Illustrations 11-13 (Int'l Risk Governance Council, 2010), available at http://www.unifr.ch/ econophysics/articoli/Helbing-Systemic_Risks_in_Society_and_Economics. pdf. For a detailed exposition on the way in which modern banking systems generate extreme complexity, see Andrew G. Haldane \& Robert M. May, Systemic Risk in Banking Ecosystems, 469 NATURE 351, $351-55$ (2011).

${ }^{327}$ See Miller \& PAGE, supra note 326, at 9-10 (describing economies as complex systems and noting how economists have only recently applied complexity theory to the field).

${ }^{328}$ In the process of this interaction, each of these agents is "co-adapting" in response to the actions and reactions of the others. Stuart Kauffman, one of the modern pioneers of complexity science, elegantly stated that they are evolving on a tableau of "dancing landscapes," in which the ground rules 
proportions. ${ }^{329}$ They have become individually and collectively complex without an obvious corresponding increase in our ability to manage them.

This development is already coming to be well understood by some economists, ${ }^{330}$ has begun attracting coverage in media commentary on financial crises $^{331}$ and has spurred debate at major

and the weather conditions are changing constantly. STUART A. KAUFFMAN, The Origins OF ORDER: SElF-Organization AND SElEction IN EVOLUTION 243-44 (1993).

${ }^{329}$ See, e.g., Manuel A. Utset, Complex Financial Institutions and Systemic Risk, 45 GA. L. REV. 780, 797-98 (2011) (defining complexity as it relates to financial institutions such that an understanding of the system requires an understanding of each component as well as the relationships among them); see also Iman Anabtawi \& Steven L. Schwarcz, Regulating Systemic Risk: Towards an Analytical Framework, 86 NOTRE DAME L. REV. 1349, 13801403 (2011) (offering a new framework for regulating complexity in the financial system).

${ }^{330}$ See, e.g., Richard S. Whitt \& Stephen J. Schultze, The New "Emergence Economics" of Innovation and Growth, and What it Means for Communications Policy, 7 J. Telecomm. \& High Tech. L. 217, 223-30 (2009) (describing "emergence economics," which views economies as "complex adaptive systems" and rejects many traditional economic theories); W. Brian Arthur, Complexity and the Economy, 284 SCIENCE 107 (1999) (arguably the seminal article on this subject). For more recognition of the increasing complexity of the financial system and how it affects the ability to regulate financial activity, see generally ERIC D. BEINHOCKER, The ORIGIN OF WEALTH: THE RADICAL REMAKING OF ECONOMICS AND WhAT IT MEANS FOR BUSINESS AND SOCIETY (2006); THE ECONOMY AS AN EvOlving COMPLEX SYSTEM (W. Brian Arthur et al. eds., 1997).

${ }^{331}$ For a range of journalism and commentary, see, e.g., Debora MacKenzie, Why the Financial System Is Like an Ecosystem, NEw SCIENTIST, Oct. 25, 2008, at 8 (2008) (offering commentary on how to predict future financial crises using complexity science); Gary Stix, The Science of Bubbles \& Busts, SCI. AM., July 2009, at 78 (reassessing how market bubbles form and crash); John Kay, Barbarians at the Gates of Complexity, FIN. TIMES (Oct. 5, 2010, 10:29 PM), http:/www.ft.com/intl/cms/s/0/902fc3d8-d0b0-11df8667-00144feabdc0.html\#axzzlounhwDou (comparing the financial crisis to the fall of overly-extended ancient civilizations); Jeffrey D. Sachs, Blackouts and Cascading Failures of the Global Markets, SCI. AM. (Dec. 22, 2008), http://www.scientificamerican.com/article.cfm?id=blackoutsand-cascading-failures (describing the systemic nature of financial crises); Duncan Watts, Too Complex to Exist, Bos. GloBE (June 14, 2009), http://www.boston.com/bostonglobe/ideas/articles/2009/06/14/too_complex _to_exist/ (suggesting preventative measures to keep the financial system 
contemporary forums involving financial leaders. ${ }^{332}$ Complexity science has also been embraced in various other quarters, including business management science and at high levels of government. ${ }^{333} \mathrm{In}$ the United Kingdom, the Government Office for Science ("GOS") recently produced a review of what it terms the "complex adaptive ultra-large-scale socio-technical system-of-systems" that the global financial markets have become. ${ }^{334}$ In the view of the GOS, system criticality (the point at which the system becomes unstable) has now significantly outstripped management capability, ${ }^{335}$ rendering the financial markets vulnerable to sudden and unexpected crashes. An example of such a crash is the so-called "Flash Crash" of May 6, 2010, in which a software-driven computer trading error triggered wildly volatile price fluctuations starting on the Chicago Mercantile

from becoming impossibly complex); R. James Breiding et al., Lost Robustness, NAISSANCE NewsL., Apr. 2009, at 8, 8-14 (analyzing the "robustness" of the financial system prior to the 2008 bankruptcy of Lehman Brothers).

332 The complexity perspective on economic stability has also gone mainstream at major events such as the World Economic Forum, which held sessions heavily influenced by complexity theory in January 2012. See Session Summary: Managing Complexity with the Santa Fe Institute, WORLD ECON. F., http://www.weforum.org/sessions/summary/managingcomplexity-santa-fe-institute (last visited Mar. 12, 2012); Martin Wolf, What Future for Economics?, Fin. TIMES (Jan. 26, 2012, 11:28 AM), http://blogs.ft.com/the-world/2012/01/what-future-for-economics/\#axzz1 ka Da7QTF (blogging on a World Economic Forum panel at which the influence of complexity economists such as Brian Arthur is strongly evident).

333 The military has used complexity theory in its strategic planning for years. The science has even begun to change approaches to management strategy within corporations. See, e.g., Richard T. PASCALE ET AL., Surfing the Edge of Chaos: The Laws of Nature and The New Laws OF BUSINESS (2001) (suggesting business strategies and principles based on complexity science). For a recent application of complexity theory, see generally IBM INST. FOR BUS. VALUE, CAPITALIZING ON COMPLEXITY (2010), available at ftp://public.dhe.ibm.com/common/ssi/ecm/en/ gbe03297usen/GBE03297USEN.PDF (studying the challenges associated with complexity that face current chief executives).

334 Dave ClifF \& Linda Northrop, The Global Financial Markets: An Ultra-Large Scale Systems Perspective 4 (2010), available at http://www.bis.gov.uk/assets/bispartners/foresight/docs/computertrading/11-1223-dr4-global-financial-markets-systems-perspective.pdf. ${ }^{335}$ See id. at 14 fig.1. 
Exchange and spreading rapidly to the New York Stock Exchange. Trading on the CME E-Mini market was automatically paused to prevent a cascade of further declines and in order to return the markets to order. ${ }^{336}$

\section{Power and Fragility in Complex Financial Systems}

The exceptional interconnectedness among the various participants within financial systems and across domestic and global economies, as well as the labile dynamics of modern finance, render global finance one of the clearest examples of a complex adaptive system. ${ }^{337}$ Just as big banks have become mutually engaged across the globe, so too have the supporting infrastructures, such as exchanges, private equity funds, mutual funds and the entire trappings of what is now called the "shadow banking system." 338 The very corporate structures of big banks, often used as vehicles for maximizing permissible forms of fund-raising and investment, introduce yet further dimensions of complexity into the overall ecology. ${ }^{339}$ Domestic and transnational regulators are themselves a part of this ecology. ${ }^{340}$

${ }^{336}$ See SEC. \& EXCh. COMM'N \& COMmodity FUtURES TRAding COMM'N, Findings REGARDING THE MARKET EVENTS OF MAY 4, 4, 6, 2010: REPORT OF THE STAFFS OF THE CFTC AND SEC TO THE JOINT ADVISORY COMMITTEE ON EMERGING REgULATORY ISSUES 6 (2010), available at http://www.sec.gov/news/studies/2010/marketevents-report.pdf (describing how, after the market closed, the exchanges and FINRA cancelled more than 20,000 trades that were executed during the twenty minute "crash" period).

337 These ideas are tentatively explored by the author in Lawrence G. Baxter, Internationalisation of Law-The 'Complex' Case of Bank Regulation, in THE INTERNATIONALISATION OF LAW: LEGISLATING, DECISION-MAKInG, PRACTICE AND EdUCATION 3 (Mary Hiscock \& William van Caenegem eds., 2010).

${ }^{338}$ For an overview of the shadow banking system, see generally POZSAR ET AL., supra note 75.

339 See, e.g., Taub, supra note 27, 196-97 (describing how holding company structures are used to enhance funding and investment possibilities and leverage, taking advantage of the Securities and Exchange Commission's "Consolidated Supervised Entities" program).

${ }^{340}$ See BRUMMER, supra note 234, passim (providing excellent analysis and description of this complex and emerging web of regulators and regulation). 
The power of this "system of systems" and its rapid growth can be attributed to the sophisticated networks that technology has enabled, through which the flow of financial transactions can run at mind-boggling speeds and volume. Yet these same networks constitute conduits for failure, as their very strength can quickly become their danger if financial difficulties arise with one of the network participants. The network that is the vehicle of efficient finance is also the mechanism through which financial contagion spreads, and this two-way flow describes the very essence of systemic risk. ${ }^{341}$

The dangers are particularly acute when the nodes in the network are themselves very large and concentrated. This is because the enormous number of network connections adhering to the nodes are all affected by the failure of the node itself, triggering what network scientists refer to as "cascading failures." 342 Complexity scientists have begun to demonstrate how very large financial institutions can constitute critical network nodes and epicenters of financial instability when one begins to fail. ${ }^{343}$ This accounts for the continuing regulatory and political concern about big banks, hitherto largely intuitive but increasingly capable of graphic and mathematical demonstration. The network is fragile, and big banks themselves are fragile by virtue of their internal complexity and operations, ${ }^{344}$ the complexity of the systems within which they

\footnotetext{
${ }^{341}$ See, e.g., Mitchell, supra note 326, at 255-57 (explaining "information spreading and cascading failures in networks"); Franklin Allen \& Douglas Gale, Financial Contagion, 108 J. ON POL. ECON. 1, 6-32 (2000) (modeling the risk associated with liquidity shocks in complex financial systems).

${ }^{342}$ For recent studies and exhibits of cascading failures in financial systems, see, e.g., Daron Acemoglu et al., Systemic Risk and Stability in Financial Networks (Jan. 8, 2012) (presentation available at http://econwww.mit.edu/files/7518). For technical analyses of financial networks, see generally Jan Lorenz et al., Systemic Risk in a Unifying Framework for Cascading Processes on Networks, 71 EuR. Physical J. B 441 (2009); Larry Blume et al., Which Networks are Least Susceptible to Cascading Failures?, in 2011 52ND ANNUAL IEEE SYMPOSIUM ON FOUNDATIONS OF COMPUTER SCIENCE 393 (2011); Ethan Cohen-Cole et al., Systemic Risk and Network Formation in the Interbank Market (Ctr. for Applied Research in Fin., Working Paper 25/2010, 2010), available at http://papers.ssrn.com/ sol3/papers.cfm?abstract_id=1799925\#\#.

${ }^{343}$ See, e.g., infra note 350 .

${ }^{344}$ See supra text accompanying notes 114-134; Utset, supra note 329, at 788-91 (describing the "general fragility of financial systems").
} 
operate $^{345}$ and the continuously evolving ecology that comprises the global financial system.

The dangers posed by increasing complexity quickly extend well beyond the interaction of complicated products within complex markets. The providers themselves - the financial institutions substantially (though usually unintentionally) add to the dangers. Regulators $^{346}$ and bankers ${ }^{347}$ alike have repeatedly acknowledged that the interconnectedness of financial institutions is the most critical factor driving systemic instability in difficult economic times. In addition to the work done by economists for developing better methods for measuring the individual systemic risk generated by individual financial institutions, ${ }^{348}$ complexity theorists, principally applying network science, have now begun to demonstrate why, in the process developing increasingly sophisticated methods for measuring the rapidly intensifying interconnectedness in the financial system. ${ }^{349}$ Increasing concentration within the financial sector reduces market resilience because larger financial institutions become more critical nodes in the overall network, such that if one

${ }^{345}$ This complexity includes not only the increased complexity of interbank relationships but also that of bank-client relationships. One recent study focusing on British banks over the past century highlights the increasing complexity of bank-client webs. As they have grown larger, companies have developed multiple bank relationships rather than replacing their prior ones. Fabio Braggion \& Steven Ongena, Hundred Years of British Firm-Bank Relationships: Why the Transition to Multiple Banking? 15-24 (Ctr. for Applied Research in Fin., Working Paper 18/2010, 2010), available at http://papers.ssrn.com/sol3/papers.cfm?abstract_id $=1799848$.

${ }^{346}$ For example, Andrew Haldane, one of the pioneers of complexity analysis in financial systems and one of the most influential thinkers on how to regulate the industry, is the executive director for financial stability for the Bank of England. See generally TAYLOR, supra note 42.

${ }^{347}$ See, e.g., Ackermann, supra note 177 ("That said, I feel that the focus of the discussion on banks' size has shifted away from what the issue actually involves: it is not size as such that is the problem but the interconnectedness of banks.").

${ }^{348}$ See, for example, the V-Lab developed at the Volatility Institute of the NYU Stern School of Business, which maintains a periodically updated roster of the global and domestic financial institutions that generated the most risk by measure of equity deficiency. NYU Stern Systemic Risk Rankings, supra note 325.

349 See, e.g., Billio et al., supra note 23, at 6-14 (outlining two methodologies for measuring the interconnectedness of financial institutions). 
collapses a large range of interconnected institutions are impacted, risking cascading failures across the system. ${ }^{350}$ Furthermore, one of the very devices used to manage risk, namely adoption of portfolios of supposedly "safe" investments such as sovereign debt, may paradoxically increase risk because of the herding effect of a concentrated group of large banks. ${ }^{351}$ Thus, one of the traditional mechanisms for risk management for the individual firm, diversification, can itself lead to systemic instability. ${ }^{352}$ In effect, whatever the value big banks provide in prosperous times, in times of economic duress they become the "super spreaders" of financial contagion, ${ }^{353}$ turning a seemingly stable financial system into one

350 See, e.g., Dion Harmon et al., Networks of Economic Market Interdependence and Systemic Risk 6 (New Eng. Complex Sys. Inst., NECSI Report 2009-03-01, 2010), available at http://arxiv4.library.cornell. edu/pdf/1011.3707v2 ("The key is that economic couplings among companies propagate the effect of failures."); Andrew G. Haldane \& Robert M. May, Systemic Risk in Banking Ecosystems, 469 NATURE 351, 352-54 (2011) (describing the cascading effect of a large bank failure); Prasanna Gai et al., Complexity, Concentration and Contagion, 58 J. MONETARY ECON. 453, 453-70 (2011) (examining "how the complexity and concentration of financial linkages can give rise to systemic liquidity crises that threaten financial system resilience."); Andrew W. Lo, Complexity, Concentration and Contagion: A Comment, 58 J. MONETARY ECON. 471, 471-73 (2011) (differentiating between complexity in nature and financial complexity on the grounds that the latter is a "demon of our own design").

351 See, e.g., Fabio Caccioli et al., Heterogeneity, Correlations and Financial Contagion 9 (Santa Fe Inst., Paper No. 11-09-044, 2011), available at http://www.santafe.edu/media/workingpapers/11-09-044.pdf ("[A] non uniform distribution of exposures implies less effective risk diversification, and we expect the probability of contagion to be affected.").

352 See Nicholas Beale et al., Individual Versus Systemic Risk and the Regulator's Dilemma, 108 PNAS 12,647 (2011) (demonstrating the tension between the distribution of assets that individual banks would like to hold and the best distribution across banks for best promoting system stability).

${ }^{353}$ See Andrew Haldane \& Robert May, The Birds, the Bees, and the Big Banks, Fin. TIMES, Feb. 21, 2011, at 9 ("Optimal strategies for preventing disease spread focus on "super spreaders": not those most likely to diet, but those with the greatest capacity to infect counterparties. The same calculus applies to big, complex banks."). For commentary, see, e.g., Lawrence Baxter, Targeting the "Super Spreaders," THEPARETOCOMMONS (Feb. 21, 2011), http://www.theparetocommons.com/2011/02/targeting-the-superspreaders/ and Beate Reszat, Banks and Biology-the Super-Spreader 
that can become radically unstable and beyond the ability of regulators to restabilize. ${ }^{354}$

This perspective has some important consequences for how we should approach the formulation of public policy regarding LCFI regulation. No matter how well a substantial financial institution is performing, in a systemic sense it always lives on the "edges of chaos, ${ }^{, 355}$ chaos which can be triggered by unexpected events that lead to chain reactions sometimes difficult to control. ${ }^{356}$ The primary objective of regulation in such circumstances, therefore, is to promote the ongoing resiliency or robustness of the financial ecology. 357

\section{Layers of Complexity in Financial Markets}

Turbulent financial complexity is generated at all levels, from product to institution to overall market.

\section{i. $\quad$ Financial Products}

Financial innovation has generated a host of new and highly complicated products. They add considerable value when used properly, even exotic products such as credit default swaps and

Analogy, REZATONLINE (June 2, 2011), http://reszatonline.wordpress. com/2011/06/02/banks-and-biology-the-super-spreader-analogy/.

${ }^{354}$ When the interconnectedness of the system itself creates the mechanism for cascading failures and collapse, complexity scientists call this "selforganized criticality." See, e.g., Helbing, supra note 326, at 6-7.

355 See MitCHELL, supra note 326, at 284-85 (describing how organisms in complex systems tend to live between states of order and chaos - i.e. on the "edge of chaos").

356 See Utset, supra note 329, at 791-93 (commenting that the financial crisis between 2007 and 2009 continued to create financial instability despite "concerted efforts by central banks around the world to contain the crisis").

357 For a practical attempt to reorient regulation toward promoting resiliency, see generally BERNICE LEE ET AL., CHATHAM HOUSE, PREPARING FOR High-IMPACT, LOW-PROBABILITY EVENTS: LESSONS FROM EYJAFJALLAJÖKULL (2012), available at http://www.chathamhouse.org/ sites/default/files/public/Research/Energy,\%20Environment\%20and\%20De velopment/r0112_highimpact.pdf. 
derivatives. ${ }^{358}$ It is not the products that are the problem on their own; it is how they interact within the overall system to create what Mr. Warren Buffett famously termed "financial weapons of mass destruction. $"{ }^{" 359}$ While Mr. Buffett aptly demonstrated the problem in the case of derivatives and their interaction with markets, ${ }^{360}$ it has also been demonstrated precisely how the systemic interaction of complicated asset-backed securities inserted into a complex overall system led to the degradation of information essential for the proper functioning of the secondary mortgage market. ${ }^{361}$

\section{ii. Operational Complexity}

The complex interactions between different business lines in diverse markets, particularly when put together in precipitous ways, have already been discussed in detail. ${ }^{362}$ This has led some commentators to declare that big banks have simply become too complex to manage. ${ }^{363}$ There is surely no doubt that it has become exceedingly difficult to manage these institutions; indeed, in trying to

${ }^{358}$ See Vira V. Acharya et al., Regulating OTC Derivatives, in REGULATING Wall StreEt: The DodD-Frank ACT AND THE NeW ARChiteCture of Global FinANCE, supra note 325, at 367, 367-69 ("It is clear that there is value to the economy from trading in derivatives, which enables users to hedge and transfer risk by altering the patterns of their cash flows.").

359 BERKSHIRE HATHAWAY INC., 2002 ANNUAL REPORT 15 (2002).

${ }^{360}$ See id. at 13-15 (explaining Berkshire Hathaway Inc.'s decision to avoid derivatives).

${ }^{361}$ See Dan Awrey, Complexity, Innovation and the Regulation of Modern Financial Markets, 1 HARV. BUS. L. REV. (forthcoming 2012) (arguing that post-financial crisis regulatory regimes fail to account for financial innovation); Kathryn Judge, Fragmentation Nodes: A Study in Financial Innovation, Complexity and Systemic Risk, 64 STAN. L. REV. (forthcoming 2012) (analyzing information loss as it causes increased risks associated with mortgage-backed securities).

${ }_{362}^{362}$ See supra text accompanying notes 114-134.

${ }^{363}$ See, e.g., Peter Thal Larsen, Global, Universal, Unmanageable? Why Many Are Wary of Bank Mega-Mergers, FIN. TIMES, Mar. 29, 2007, at 13 ("[W]hile size may offer some benefits, it can also introduce complexity into a business that makes it harder to manage effectively."); John Kay, Banks Brought Down by New Peter Principle, Fin. TiMES (Aug. 25, 2009, 7:42 PM), http://www.ft.com/intl/cms/s/0/861 f8e84-91a3-11de-879d00144feabdc0.html\#axzzlniEUducu (suggesting that financial institutions "extend their scope into activities they understand less until they are tripped up by one they cannot do"); Fox-Penner, supra note 266. 
steer them back to stable profitability, CEOs of a number of big banks have concentrated on shedding lines of business in order to restore managerial focus. ${ }^{364}$ The European banking regulator ordered the break-up of ING for this reason. ${ }^{365}$

Operational complexity further compounds an already complex environment in which the unexpected can and often does occur, thereby creating a perpetual hazard of unexpected (and unpredictable) difficulties in the overall financial system.

\section{iii. Regulatory Complexity}

The struggles by regulators to cope with this proliferating volume and rapidly changing business have also been reviewed. ${ }^{366}$ This has led many commentators to assert that, given the complexity of the institutions and the limitations on regulatory resources, LCFIs have become too complex to regulate. ${ }^{367}$

Yet the problem is even deeper and more paradoxical because an additional dimension of complexity has also begun to manifest itself in the form of "regulatory complexity." ${ }^{368}$ Regulatory

${ }^{364}$ For examples involving Citi and BofA, see, e.g., Donald Griffin, Citigroup Says Bank Will Exit Mortgage Brokerage Business, BLOOMBERG BUSINESSWEEK, (Feb. 6, 2012, 12:55 PM), http://www.businessweek.com/ news/2012-02-06/citigroup-says-bank-will-exit-mortgage-brokeragebusiness.html; BofA to Exit Correspondent Mortgage Business, ReUTERS (Aug. 31, 2011, 4:54 PM), http://www.reuters.com/article/2011/08/31/usbofa-mortgagebusiness-idUSTRE77U0PB20110831. For European examples, see, e.g., Heather Landy, U.K. Moves Could Point Way in U.S. On 'Too Big', Am. BAnKer, Nov. 4, 2009, at 1; Putting Competition First: Lloyd's and Royal Bank of Scotland Are Forced to Sell Businesses, ECONOMIST (Nov. 3, 2009), http://www.economist.com/node/14789749.

${ }^{365}$ See generally Patrick Jenkins et al., Regrets are scarce over bank break ups, Fin. TiMES, Oct. 29, 2009, at 16; Michael Steen, ING to Be Broken Up in Wake of Bail-Out, Fin. TIMES, Oct. 27, 2009, at 1. For a discussion linking the ING break-up to the break-up of Lloyds, see Lawrence Baxter, Financial Macrophilia and Shrinking the Banks, PARETO COMMONS (Sept. 24, 2010), http://www.theparetocommons.com/2010/09/financialmacrophilia-and-shrinking-the-banks/.

${ }^{366}$ See supra text accompanying notes 271-286.

367 This position is powerfully argued in Peter Fox-Penner, Too Big to Regulate?, BASELINE SCENARIO (Jan. 16, 2010), http://baselinescenario. com/2010/01/16/too-big-to-regulate/.

${ }^{368}$ See Karen Shaw Petrou, Managing Partner, Fed. Fin. Analytics, Inc., The Complexity-Risk Conundrum: Why SIFIs Can't be Both Bullet-Proof and 
complexity stems not only from the huge volume of new regulations $^{369}$ and regulators ${ }^{370}$ being hurled at the financial industry in an attempt to reduce the risk of financial instability, but also from the inherent contradictions in our public policy objectives, overlaps in agency missions, and the ebb and flow of political accountability that applies to regulators. ${ }^{371}$

For example, we have not resolved whether we are regulating big banks as if they are part of a free enterprise system in which bankruptcy is the realistic result for one that fails, or

Profit-Making: Remarks Prepared for the Securities Industry and Financial Markets Association 1 (Jan. 10, 2012) (transcript available at http://www.fedfin.com/images/stories/press_center/speeches/SIFMA_Speec h.pdf) (asserting that "if we don't understand the cross-cutting effects and inherent contradictions in all of the stringent standards now being written into final form, we risk doing real damage to the sound, stable and ... profitable ... financial industry).

${ }^{369}$ See Davis PolK \& WARDWELl LLP, DodD-FranK RULE MAKING AND PROGRESS REPORT 5-6 (2011), available at http://www.davispolk. com/files/uploads/FIG//040411_ProgressReport.pdf (reporting the monumental number of rules remaining to be written to fully implement the regulations mandated by the Dodd-Frank Act); Phillip Härle et al., Basel III and European banking: Its impact, how banks might respond, and the challenges of implementation 22-24 (McKinsey \& Co., McKinsey Working Paper on Risk No. 26, 2010) (describing the complexity introduced by compliance with Basel III).

370 See Aaron Lucchetti, The Regulator Down the Hall: Fed and Comptroller of Currency Bolster the Ranks of Staffers 'Embedded' at Nations' Biggest Banks, WALL ST. J., June 20, 2011, at C1 (describing the increased scrutiny imposed on financial institutions due to the growing number of regulators, many of whom are stationed at the institutions). The author has elsewhere argued that there is a more abstract benefit to the proliferation of multiple regulators, namely that their differing perspectives help generate more refined views on public policy. See generally Lawrence Baxter, Understanding Regulatory Capture: An Academic Perspective from the United States, 47 WAKE FOREST L. REV. (forthcoming Spring 2012) (manuscript at 9-11) (on file with the author).

${ }^{371}$ For example, the 2010 congressional elections transferred power in the House Financial Services Committee from Democrats to Republicans, and this completely changed the Committee's agenda from one that supported increased regulation to one that vigorously opposes it. Press Release, Comm. on Fin. Servs., Bachus Welcomes New Members to Financial Services Committee (Dec. 10, 2010), available at http:// financialservices.house.gov/News/DocumentSingle.aspx? DocumentID=227 759. 
regulating them as public utilities that cannot be permitted to fail and, as such, are effectively wards of the state. ${ }^{372}$ This confusion in mission repeatedly sends mixed signals to financial institutions. Additionally, because political winds change in response to events, regulators tend to take precautionary action. Yet when their missions are in conflict, ${ }^{373}$ the precautionary action can lead to confusion. ${ }^{374}$ The ultimate results are highly uncertain; this in itself is likely to contribute to erratic behavior on the part of market participants as they guess which path government support will take. ${ }^{375}$ Finally, the grand conflict of interest stemming from the needs of public finance, which has already been described, ${ }^{376}$ may contribute to an "intervention paradox" in which governments are most reluctant to

372 See supra text accompanying notes 174-98 (discussing the ways in which the government has intervened to prevent potential bank failures).

${ }^{373}$ For example, the fundamental missions of the OCC and the FDIC are sometimes in conflict. The OCC has an interest in a flourishing national bank industry as a part of its very raison d'être, and the FDIC has an interest in protecting the deposit insurance fund by preventing its exposure to unnecessary risk. A recent illustration of this conflict was the divergence of views on BofA's decision to transfer its derivatives portfolio into its insured bank to reduce the degree of collateral required by counterparties. See Bob Ivry et al., BofA Said to Split Regulators Over Moving Merrill Derivatives to Bank Unit, BloOMBERG (Oct. 18, 2011, 1:56 PM), http://www. bloomberg.com/news/2011-10-18/bofa-said-to-split-regulators-over-

moving-merrill-derivatives-to-bank-unit.html (reporting that the Fed and FDIC disagree over the transfers). Another example is the difference of opinion between the Fed and the FDIC over whether trust preferred securities should qualify as regulatory capital. See generally Donna Borak, In Feud Over Capital, FDIC Besting Fed, AM. BANKER, May 26, 2010, at 1. 374 See, e.g., Eugene F. Maloney, Banks and the SEC: A Regulatory Mismatch?, 25 ANN. REV. BANKING \& FIN. L. 443, 460 n.53 (2006) (describing many examples, one of which was whether a cautious approach to loan loss reserves, which the bank regulators favored, was compatible with the SEC's market disclosure expectations).

${ }^{375}$ Market participants struggle to cope with the uncertainty of regulatory reforms, despite contributing to the uncertainty by actively opposing such reforms. See Editorial, The Uncertainty Principle: Dodd-Frank Will Require At Least 243 New Federal Rule-Makings, WALL ST. J., Jul. 14, 2010, at A18 (describing the vast and uncertain scope of implementation of the DoddFrank Act).

${ }^{376}$ See supra text accompanying notes 193-207 (discussing the role of banks in public finance and the resulting conflict of interest). 
intervene to prevent bank failure at precisely the point when they should intervene most forcefully. ${ }^{377}$

The situation presents a classic example of how the regulators themselves are important interactive agents within the overall complex adaptive system of systems. Complexity theorists would quickly observe that the circumstances strongly indicate that traditional forms of regulation will not prove successful. ${ }^{378}$

\section{iv. Prediction in Complex Financial Markets}

The newly perceived importance of developing better methods for predicting potential system failures is one of the byproducts of the Financial Crisis. In the United States, for example, the Dodd-Frank Act created the Office of Financial Research within the Treasury Department for the purpose of gathering and correlating data that might better provide early warning of impending systemic stress. ${ }^{379}$ The agenda is an ambitious one that is likely only to achieve results if sophisticated concepts of complexity theory are applied.

377 See Lawrence G. Baxter, Did We Tame the Beast: Views on the US Financial Reform Bill, 2 J. REG. \& RISK N. ASIA 209, 215 (2010) (describing the intervention paradox as the tendency of regulators to decline to "shut down a large, systemically risky institution because . . . just when the need to ... seize a financial institution is greatest, the incentives not to do so, and the ability of the institution itself to resist seizure, are also highest").

378 There is a growing literature surveying early ideas regarding the development of adaptive regulation for better addressing complex adaptive systems. See, e.g., Lawrence G. Baxter, Adaptive Regulation in the Amoral Bazaar, 128 S. AFR. L.J. 253, 264-268 (describing how new concepts of regulation become important when addressing highly complex systems); Donald T. Hornstein, Complexity Theory, Adaptation, and Administrative Law, 54 DUKE L.J. 913, 917-28 (2005) (introducing complexity theory generally and stressing the importance of adaptation); J.B. Ruhl, General Design Principles for Resilience and Adaptive Capacity in Legal SystemsWith Applications to Climate Change Adaptation, 89 N.C. L. REV. 1373 (2011) (containing many ideas relevant to financial regulation); Charles K. Whitehead, Destructive Coordination, 96 CoRNELl L. REV. 323, 346 (2011) (focusing on the inapposite nature of command-and-control, coordinated regulation in modern markets, which function without such central direction).

${ }^{379}$ On the OFR, its relationship to the FSOC and its mandate, see supra text accompanying notes $287-288$. 
The complexity approach to financial markets has begun to spawn new ideas about how financial crises might be predicted ${ }^{380}$ and regulated more effectively, ${ }^{381}$ how investors might become better at managing portfolios in light of the fact that markets are constantly adaptive and not necessarily efficient, ${ }^{382}$ and how one might become better at managing Black Swan events that render risk management models wildly inaccurate. ${ }^{383}$ Yet the science of predicting the dynamics of complex markets remains in its infancy; much more work remains before we can develop a sophisticated understanding of the complex features of financial markets and their impacts on

${ }^{380}$ See, e.g., Dion Harmon et al., Predicting Economic Market Crises Using Measures of Collective Panic 2-9 (New Eng. Complex Sys. Inst., NECSI Report 2010-08-01, 2011), available at http://arxiv.org/pdf/1102. 2620v1.pdf.

${ }^{381}$ See, e.g., Christopher Arup, The Global Financial Crisis: Learning from Regulatory and Governance Studies, 32 LAW \& POL'Y 363, 373-78 (2010) (contemplating prospects for reform of the financial industry based on recent regulatory and governance studies); Baxter, supra note 378, at 264268 (highlighting the advantages of adaptive regulation in complex systems); Julia Black \& Robert Baldwin, Really Responsive Risk-Based Regulation, 32 LAW \& POL'Y 181, 186-88 (2010) (arguing that "regulators have to regulate in a way that is responsive to five elements: (1) regulated firms' behavior, attitude, and culture; (2) regulation's institutional environments; (3) interactions of regulatory controls; (4) regulatory performance; and (5) change."); Daniel Carpenter, System Failure: How to Think About Financial Regulation in an Era of Systemic Risk, DEMOCRACY J., Fall 2011, at 98, 103-05 (reviewing KATHLEEN ENGEL \& PAtricia McCoy, The SubPrime Virus: ReCKLESS CREdit, Regulatory FaILURe, AND NEXT STEPS (2011)) (considering the authors' argument that the financial industry, because it is interconnected, requires a different kind of regulation that incorporates all of the unique goals of the separate regulatory agencies); Schwarcz, supra note 268, at 236-62 (discussing areas in which new financial regulation is desirable and also other areas in which "unnecessary regulation should be avoided to minimize unintended, often adverse, consequences").

382 See, e.g., Andrew W. Lo, Adaptive Markets and the New World Order 11-17 (Dec. 30, 2011) (unpublished manuscript), available at http://ssrn. com/abstract $=1977721$.

383 See generally Nassim Nicholas Taleb, Prologue to The Black Swan: The Impact Of The Highly Improbable, at xvii (2d ed. 2010) (defining Black Swan events, such as the financial crisis, as those with rarity, extreme impact and retrospective predictability). 
participants, let alone develop more effective methods for anticipating instability and managing it before and when it occurs.

\section{Two General Consequences for Public Policy}

A vast array of current and potential policies, which are beyond the scope of this article and already addressed in numerous other more specialized ones, are invoked by this extraordinarily complex system of systems, organizations and activities. In the face of the indeterminate value of big banks ${ }^{384}$ and the extraordinary complexity of the financial system, its participants, products and solutions, ${ }^{385}$ two much less discussed general consequences are strongly implied. First, the public accountability and governance of big banks might have to be conceived differently. Second, given the risk of great harm in the event of failure, a precautionary principle should be applied whenever weighing the costs and benefits of a proposed merger or the continued growth of a big bank.

\section{A. Public Accountability}

To the extent that extensive public subsidies support the operations and profitability of big banks, ${ }^{386}$ it would seem that big banks ought to be subjected to a greater degree of public accountability than ordinary commercial institutions. The ramifications of this principle, which are likely to range from far greater transparency requirements in corporate reporting to modifications in the fiduciary duties of executives and boards of directors, would be far reaching and would require some careful analysis.

The unusual role of big banks, as compared to other commercial and industrial firms, is well illustrated by the events surrounding Bank of America's acquisition of Merrill Lynch. With strong encouragement from both the then-Secretary of the Treasury, Hank Paulson, and the Chairman of the Fed, Ben Bernanke, Ken Lewis, then CEO of Bank of America, agreed to acquire the investment bank, which was near collapse and too large to let slide into bankruptcy, particularly after Lehman had been allowed to fail. Yet as the full details of Merrill Lynch's condition became evident to

\footnotetext{
${ }^{384}$ See supra Parts I \& II.

385 See supra Part III.

${ }^{386}$ See supra text accompanying notes $227-245$.
} 
Bank of America, Mr. Lewis realized that the acquisition was a mistake. On December 17, 2008, he informed Mr. Paulson that Bank of America was seriously considering invoking a material adverse condition ("MAC") clause to withdraw from the acquisition. After being asked not to invoke the MAC without further consultation, Mr. Lewis again informed Mr. Paulson four days later that Bank of America wanted to back out of the deal. Mr. Paulson warned Mr. Lewis that if Mr. Lewis and his board were to invoke the MAC clause, the board could and probably would be replaced. Mr. Bernanke apparently asked Mr. Paulson to make clear to Mr. Lewis that the dissolution would create a systemic risk to the financial system. Mr. Lewis quickly changed his mind and advised his board accordingly. The board agreed and the merger was closed soon afterward. ${ }^{387}$

The conventional legal view is that in complying with the pressure brought by two government officers and not disclosing this pressure to shareholders, Mr. Lewis may well have violated his duty to shareholders by complying with the demand to conclude the Merrill Lynch merger. Indeed, Mr. Lewis apparently feared that he and his board would be sued, ${ }^{388}$ and leading commentators went on

387 For one of many similar versions of this incident, see Letter from Andrew Cuomo, Attorney Gen., N.Y. State Office of the Attorney Gen., to Christopher J. Dodd, Chairman, U.S. Senate Comm. on Banking, Hous. \& Urban Affairs, Barney Frank, Chairman, House Fin. Servs. Comm., Mary, L. Schapiro, Chairman, U.S. Sec. \& Exch. Comm'n and Elizabeth Warren, Chair, Cong. Oversight Panel (Apr. 23, 2009), available at http://www.ag.ny.gov/sites/default/files/press-releases/archived/BofAmerg Letter.pdf; ROTHACKER, supra note 120, at 169-75.

${ }^{388}$ Under the corporate law of most states, directors have a duty to "[act] on an informed basis, in good faith and in the honest belief that the action [is] in the best interests of the company." Smith v. Van Gorkom, 488 A.2d 858, 872 (Del. 1985) (quoting Aronson v. Lewis, 473 A.2d 805, 812 (Del. 1984)). Some have charged that BofA failed to, amongst other things, conduct proper due diligence, monitor the on-going financial condition of Merrill and make timely disclosure to shareholders. See, e.g., Mark T. Williams, A Breach of Fiduciary Duty at Bank of America, FORBES (Feb. 26, 2009, 6:18 PM), http://www.forbes.com/2009/02/26/bank-americafiduciary-opinions_merrill_lynch.html (arguing that "there were at least seven critical decision points where [Bank of America] . . . could have acted to protect the company and its shareholders."). 
record to assert that Mr. Lewis had committed a violation of his fiduciary responsibilities. ${ }^{389}$

It is the submission of this article that the traditional view is wrong. Big banks playing such roles are, in effect, extensions of the state. ${ }^{390}$ This strongly suggests that the third major stakeholder at the table, namely the government, as provider of subsidies and protector of big banks and requiring extreme confidentiality at the moment of decision, could not simply be ignored out of reliance on traditional principles of fiduciary duty to shareholders. ${ }^{391}$

If the reasoning in this example is correct, then the traditional standards of corporate governance and private confidentiality seem in some ways inapposite to big banks. It would seem starkly anomalous to allow such quasi-public entities to fall back on traditional standards, developed to secure the operation of privately-owned firms in a free market, and thereby preclude recognition of the interests of the public, which has a major stake in their outcome and supports their very existence. Just as the benefit of federal deposit insurance is invoked as the rationale for extensive and intrusive bank regulation, the exceptional role of big banks therefore calls for a re-examination of traditional principles of corporate governance and accountability.

\section{B. Progressively Tighter Restrictions on Bank Growth and Diversification}

Given the great uncertainty of success ${ }^{392}$ and the severe impact of failure, ${ }^{393}$ regulators should also continue to intensify growth retardants on big banks. Some restrictive norms have already been imposed. These take the form of deposit and liability caps for

${ }^{389}$ See Dennis K. Berman, Are Ken Lewis, Ben Bernanke and Hank Paulson Heroes or Goats?, WALL ST. J. (Apr. 23, 2009, 8:36 AM), http://blogs.wsj. $\mathrm{com} /$ deals/2009/04/23/are-ken-lewis-ben-bernanke-and-hank-paulsonheroes-or-goats/ (quoting Professor Jonathan R. Macey, Sam Harris Professor of Corporate Law, Corporate Finance, and Securities Law at Yale Law School, as stating "[i]f you're the CEO, your first obligation is not to your regulator, it's to your institution and shareholders.").

${ }^{390}$ See supra text accompanying notes 193-199.

${ }^{391}$ See supra text accompanying note 388.

${ }^{392}$ See supra text accompanying notes 221-224.

${ }^{393}$ See supra text accompanying notes 18-24. 
bank mergers, ${ }^{394}$ a regime of "enhanced supervision" by the Fed ${ }^{395}$ and special standards for G-SIFIs under Basel III. ${ }^{396}$

The approach of the empowered agencies, however, has so far been mild, at least in the United States. The FSOC has failed to make significant recommendations to Congress concerning the effects of size and interconnectedness. ${ }^{397}$ At the same time, the Fed appears, in light of the Dodd-Frank Act, to be approaching the continuing merger of very large banks more strictly. ${ }^{398}$ Acting under the authority of the Dodd-Frank Act, the Fed appears to have conducted a much more extensive and intrusive analysis concerning a recent proposed merger that would result in the formation of one much larger bank. The industry claims this approach poses new obstacles to big bank mergers. ${ }^{399}$ Whether the Fed will exercise its new powers to force reductions in size, or prevent the continued growth of existing firms, remains to be seen.

Although the Fed now appears to be demonstrating a more active role, the situation calls for an even more intrusive role that strongly promotes the public interest at stake when the scale and complexity of big banks are evaluated for safety and viability. The traditional approach assumes that the actual and potential benefits of big bank growth are proven, whereas they are as much putative as they are real. It also has traditionally been assumed that the risks of permitting or even ignoring big bank growth are somehow justified by a "market approach" to the tolerance of failure-yet the genuine threat of bankruptcy seems very unlikely. ${ }^{400}$ Finally, whereas assertions of future bank prosperity are given deferential weight, very tangible costs to the public are blithely ignored: the complete absence of analyses of the public costs of and support for big banks suggests that the supposed benefits of big banks should be expressly counterbalanced by these very real public costs. ${ }^{401}$ There may or may

${ }^{394}$ See supra text accompanying notes 217-219.

395 See generally Dodd-Frank Act, Pub. L. No. 111-203, § 113, 124 Stat. 1376, 1398-1402 (2010) (to be codified at 12 U.S.C. $§ 5323$ ).

${ }^{396}$ See supra text accompanying note 295.

397 See supra text accompanying notes 217-220.

398 See CapOne Ruling, supra note 252, at 6-38 (conducting an extensive and detailed analysis of "all the facts of record in light of the factors that [the Fed] is required to consider under the BHC Act.").

399 See supra text accompanying notes 320-324.

${ }^{400}$ See supra part II.A.

${ }^{401}$ See supra part II. 
not be an exciting future for big banks. Any honest review of the past decade indicates, however, that their record is generally poor. ${ }^{402}$ To continue to make the deferential assumptions that they can perform safely as they grow is to give hostage to fortune.

Whether they are in delicate financial condition or merging to grow larger, a more realistic approach would cast a heavy onus on big banks to demonstrate in tangible terms how:

1. they propose to develop safer structures and operations that would more effectively insulate other financial institutions and the financial system itself from the consequences of failure or threat of failure; ${ }^{403}$

2 . in the event of a proposed merger, they would adjust for the new scale upon which they would operate, both in safe competition and proper risk management; and

3. regulators would be able to cope with, both with regard to resources and conceptually,

${ }^{402}$ See infra Appendix, Chart 2 (depicting a decline in return on equity for big banks over the last ten years).

${ }^{403}$ Various current measures, such as the separation of proprietary trading and banking mandated by the Volcker Rule, see Dodd-Frank Act $§ 619$ (to be codified at 12 U.S.C. $\S 1851$ ), and the "ring-fencing" separation between retail banking and corporate and investment banking proposed by the Vickers Report and being implemented by the British Government, see, e.g., Barnabus Reynolds, The Proposed Restructuring of the UK Financial Regulatory Framework, HARV. L. SCH. F. CORP. GOVERNANCE \& Fin. REG. (Oct. 17, 2011, 10:13 AM), http://blogs.law.harvard.edu/corpgov/ 2011/10/17/the-proposed-restructuring-of-the-uk-financial-regulatoryframework/, attempt to insert "modular" structural elements in an effort to prevent the quick spread of defaults when a big bank fails. These measures are controversial, but the basic ideas are compatible with the complexity science approach to system regulation. See Lawrence G. Baxter, Size, Subsidiarization and Stability, PARETO COMMONS (Jan. 24, 2011), http://www.theparetocommons.com/2011/01/size-subsidiarization-andstability/ (advocating for the use of "modularity" in the enactment of legislation relating to systemically risky institutions). 


\section{the increased supervisory demands that bigger banks require. ${ }^{404}$}

Developing such requirements would, in effect, create a new regime of strict caution, in which new precautionary principles of supervision $^{405}$ and more aggressively developed existing ones would combine, in effect, to impose a progressively intensifying governor or constrictor on the process of big bank evolution. ${ }^{406}$ In effect, it would be made harder and harder for large banks to convince regulators that their large size, complexity and continued growth are

${ }^{404}$ This point is particularly relevant, as budget cutting by Congress has left regulators with even fewer resources than before. See Ben Protess, U.S. Face Budget Pinch as Mandates Widen, N.Y. Times DeALB\%K (May 3, 2011, 8:50 PM), http://dealbook.nytimes.com/2011/05/03/u-s-regulatorsface-budget-pinch-as-mandates-widen/ (reporting that budget cuts will frustrate rulemaking mandated by the Dodd-Frank Act). Currently, proposed mergers are not required to express the costs of additional or compounded supervision. 12 U.S.C.A. § 1842(c) (West 2012).

${ }^{405}$ While the author would not necessarily advocate treating big banks as if they were utilities - a topic for much fuller discussion - an example from the regulation of electricity suppliers is relevant here. In Duke Energy Corp., 137 FERC I 61,210 (2011), the Federal Energy Regulatory Commission ruled that two parties to a proposed merger had not sufficiently demonstrated that their proposed measures to mitigate the merger's anticompetitive effects would be adequate. When compared with the Fed's analysis in the CapOne Ruling, supra note 252, the Duke Energy Corp. decision seems to suggest a more rigorous competitive analysis by the FERC.

${ }^{406}$ In addition to imposing capital "surcharges" on ultra-large banks, see supra note 295, an area in which regulators can continue to build is that of orderly resolution plans, or "living wills," which are being required of large banks and financial holding companies under the Dodd-Frank Act. DoddFrank Act $\S \S 201-217$ (to be codified in scattered sections of the U.S.C.); see also 12 C.F.R. § 243.2-.9 (2012) (requiring resolution plans for certain bank holding companies and non-bank financial institutes supervised by the Fed); 12 C.F.R. $\S 381.2-.9$ (2012) (requiring resolution plans for certain large banks); 12 C.F.R. § 360.1-.10 (2012) (outlining resolution and receivership rules). Detractors dismiss these plans as irrelevant because they do not specify the actions necessary in the event of a large failure. But this misses the point of the plans, which is to provide an opportunity for both the financial institution and the regulators to take stock of the capabilities and manageability of the organization. This opportunity rarely presents itself in the ordinary course of business and, unless it is mandated across the industry, would likely never present itself. 
not threats to financial stability. This regulatory direction would no doubt be highly unpopular with big bankers as they glibly talk of further waves of consolidation. ${ }^{407}$ But they are, of course, not the only ones with a stake in the maintenance of financial stability.

\section{Conclusion}

Big banks might offer clear benefits, both to shareholders and consumers. ${ }^{408}$ At the same time there is no question that these benefits come at considerable cost to the public, costs that are not ordinarily internalized by the banks and are not borne directly by shareholders or end users of their services. Instead, these costs are externalized to the public in general. ${ }^{409}$ This imbalance alone calls for policies that strive to ensure that the costs of big bank activities are more accurately allocated to those who benefit from them, and that greater precautions are taken to mitigate the costs of the big bank experiment.

While a huge range of special policies have been applied to, or have been proposed for, big banks, from outright reduction in size to special capital requirements, there seems to be at least two general policies that ought to be developed much more fully under all circumstances. Banks ought to be subjected to greater public accountability, and they ought to bear the onus of credibly demonstrating that maintenance of their current scale or their continued expansion, whether through organic growth or mergers, is plausibly sustainable from the twin perspectives of financial stability and public cost.

These are controversial proposals, no doubt, but they are ones that honestly recognize all the costs and benefits of big banks as well as the exceptional hazards they create. By embracing these policies, regulators, congressional committees and the public would be better positioned to call for specific responses from big banks and expect credible plans rather than the usual rhetorical rejection we hear from the captains of the big banks whenever they are faced with proposals for reform.

\footnotetext{
${ }^{407}$ See Harper, supra note 17.

${ }^{408}$ See supra text accompanying notes 172-192.

${ }^{409}$ See supra text accompanying notes 221-244.
} 


\section{Appendix}

\section{Chart 1 (Efficiency Ratio) ${ }^{410}$}

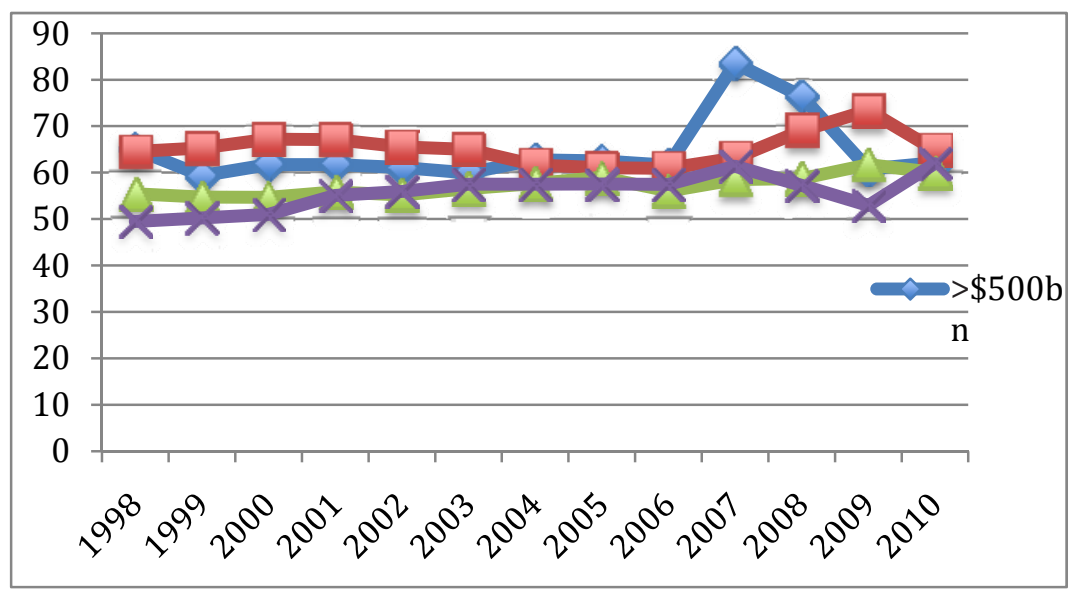

410 Banks are categorized by total assets. This chart is based on the efficiency ratios listed on Bloomberg LP's terminal as of Feb. 2012 and includes the following financial institutions: BofA, Citi, JP Morgan, TD Bank US Holding Company, Ally Fin. Inc., Regions Fin. Corp., BMO US Equity, Wells, Sun Trust, Key Corp Cleveland, State Street Corp., Bank of New York Mellon, PNC Fin. Servs., Fifth Third Bancorp, BB\&T Winston Salem, US Bancorp Minneapolis, Wachovia, Goldman Sachs, Morgan Stanley, Lehman Bros., Merrill, M\&T Bank Corp., Northern Trust Corp., First Commonwealth Fin. Corp., New York Community Bancorp Inc., First Midwest Bancorp, Inc., Bank of Commerce Holdings, Auburn National Bancorporation, Timberland Bancorp, F\&M Bank Corp. and Southern Missouri Bancorp. 


\section{Chart 2 (Return on Equity) ${ }^{411}$}

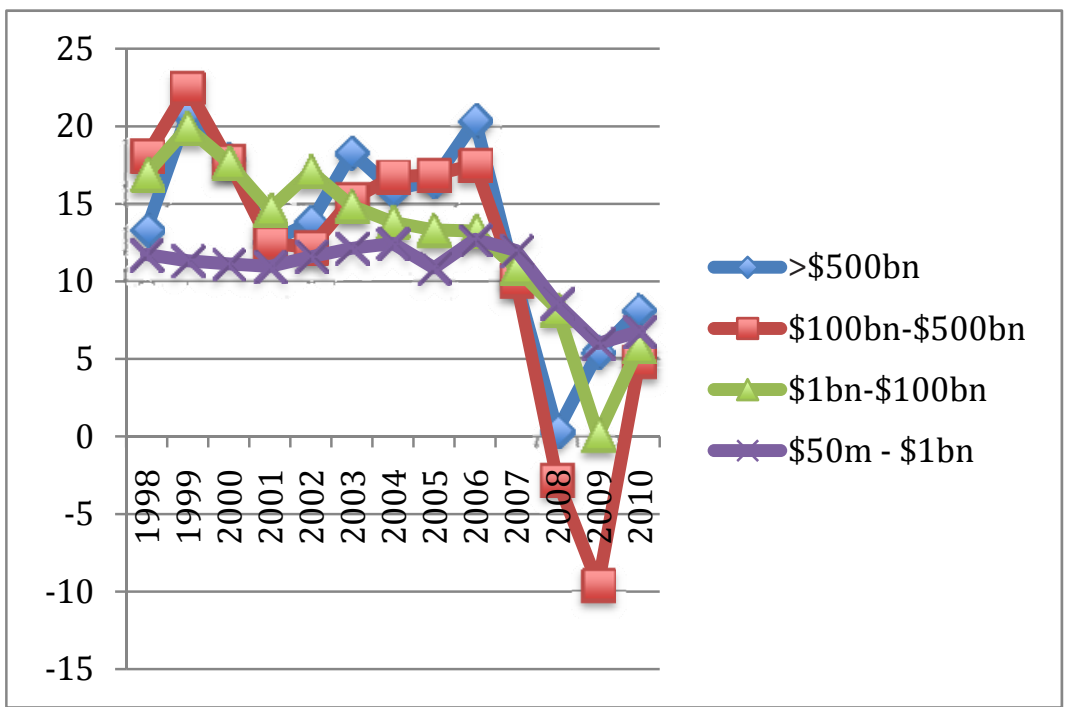

${ }^{411}$ This chart is based on the returns on equity listed on Bloomberg LP's terminal as of Feb. 2012 and includes the following financial institutions: BofA, Citi, JP Morgan, TD Bank US Holding Company, Ally Fin. Inc., Regions Fin. Corp., BMO US Equity, Wells, Sun Trust, Key Corp Cleveland, State Street Corp., Bank of New York Mellon, PNC Fin. Servs., Fifth Third Bancorp, BB\&T Winston Salem, US Bancorp Minneapolis, Wachovia, Goldman Sachs, Morgan Stanley, Lehman Bros., Merrill, M\&T Bank Corp., Northern Trust Corp., First Commonwealth Fin. Corp., New York Community Bancorp Inc., First Midwest Bancorp, Inc., Bank of Commerce Holdings, Auburn National Bancorporation, Timberland Bancorp, F\&M Bank Corp. and Southern Missouri Bancorp. 
Chart 3 (Return on Assets) ${ }^{412}$

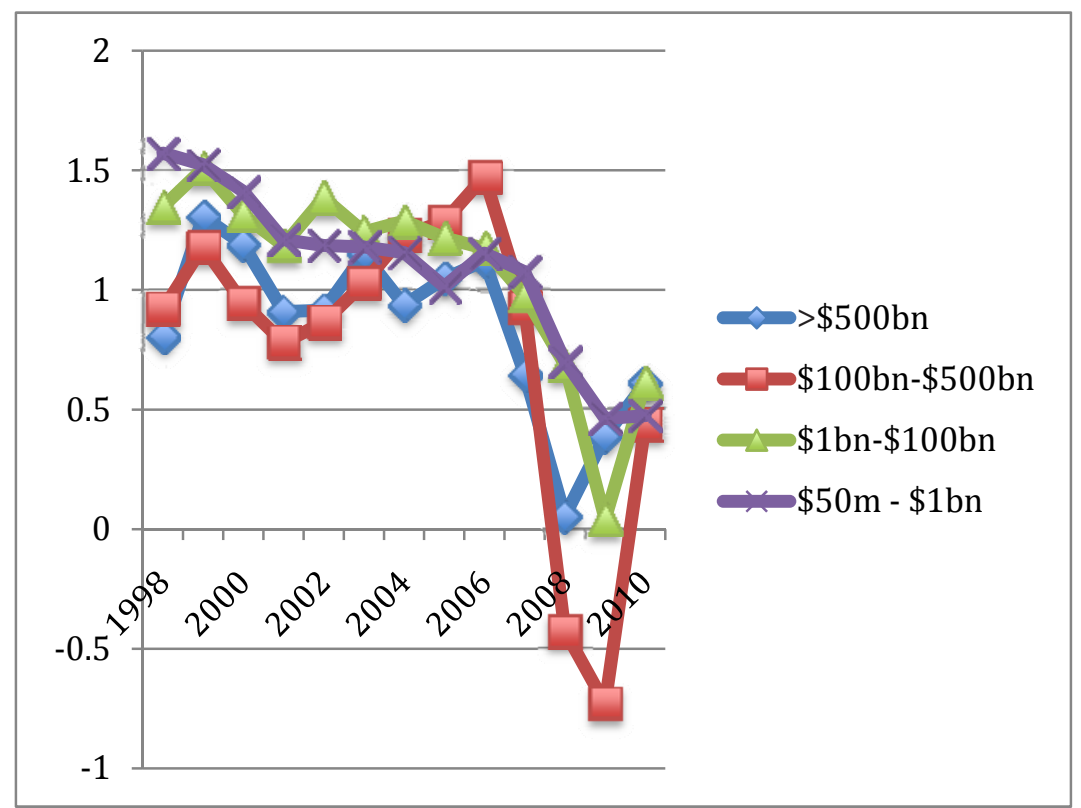

${ }^{412}$ This chart is based on the returns on assets listed on Bloomberg LP's terminal as of Feb. 2012 and includes the following financial institutions: BofA, Citi, JP Morgan, TD Bank US Holding Company, Ally Fin. Inc., Regions Fin. Corp., BMO US Equity, Wells, Sun Trust, Key Corp Cleveland, State Street Corp., Bank of New York Mellon, PNC Fin. Servs., Fifth Third Bancorp, BB\&T Winston Salem, US Bancorp Minneapolis, Wachovia, Goldman Sachs, Morgan Stanley, Lehman Bros., Merrill, M\&T Bank Corp., Northern Trust Corp., First Commonwealth Fin. Corp., New York Community Bancorp Inc., First Midwest Bancorp, Inc., Bank of Commerce Holdings, Auburn National Bancorporation, Timberland Bancorp, F\&M Bank Corp. and Southern Missouri Bancorp. 
Table 1

Average Ratings Difference for a Sample of Banks and Building Societies $^{413}$

\begin{tabular}{|l|l|l|l|l|}
\hline & \multicolumn{1}{|c|}{$\mathbf{2 0 0 7}$} & $\mathbf{2 0 0 8}$ & $\mathbf{2 0 0 9}$ & Average \\
\hline United Kingdom & 1.56 & 1.94 & 4.00 & 2.50 \\
\hline Global & 1.68 & 2.36 & 2.89 & 2.31 \\
\hline Average & 1.63 & 2.21 & 3.24 & 2.36 \\
\hline
\end{tabular}

1. All figures are year-end.

2. The sample for the United Kingdom contains sixteen banks and building societies in 2007 and 2008, and thirteen in 2009. The global sample contains a sample of twenty-six banks across a range of sizes and countries for 2007, and twenty-eight banks in 2008 and 2009.

Source: Moody's and Bank calculations

${ }^{413}$ Haldane, supra note 42 , at 24 , tbl.2. 
Table 2

Average ratings difference for UK banks and building societies ${ }^{414}$

\begin{tabular}{|c|c|c|c|}
\hline Category & Mean & $\begin{array}{c}\text { Maximum } \\
\text { Difference in } \\
\text { Sample }\end{array}$ & $\begin{array}{c}\text { Minimum } \\
\text { Difference in } \\
\text { Sample }\end{array}$ \\
\hline \multicolumn{4}{|l|}{2007} \\
\hline Large banks & 2.67 & 12 & 1 \\
\hline Small Banks & .14 & 1 & 0 \\
\hline \multicolumn{4}{|l|}{2008} \\
\hline Large Banks & 2.78 & 10 & 1 \\
\hline Small Banks & .86 & 2 & 0 \\
\hline \multicolumn{4}{|l|}{2009} \\
\hline Large Banks & 4.67 & 7 & 3 \\
\hline Small Banks & 3.43 & 6 & 0 \\
\hline \multicolumn{4}{|l|}{ Average } \\
\hline Large Banks & 3.37 & 10 & 2 \\
\hline Small Banks & 1.48 & 3 & $\mathbf{0}$ \\
\hline
\end{tabular}

(a) The "Large" category includes HSBC, Barclays PLC, RBS, Lloyds TSB, Alliance \& Leicester, Bradford \& Bingley (up to 2008) and Nationwide. The "Small" category includes building societies: Chelsea, Coventry, Leeds, Principality, Skipton, West Bromwich and Yorkshire. The ratings are year-end.

Source: Moody's and Bank calculations

${ }^{414}$ Haldane, supra note 42 , at 24 , tbl.3. 